Florida A\&M University College of Law

Scholarly Commons @ FAMU Law

1999

The Independent Counsel Statute: A Legal History

Benjamin Priester

Follow this and additional works at: https://commons.law.famu.edu/faculty-research

Part of the Criminal Law Commons, Public Law and Legal Theory Commons, and the Rule of Law Commons 


\title{
THE INDEPENDENT COUNSEL STATUTE: A LEGAL HISTORY
}

\author{
BenJamin J. Priester, ${ }^{*}$ PAul G. Rozelle, ${ }^{* *}$ AND Mirah A. \\ HOROWITZ***
}

\section{TABLE OF CONTENTS}

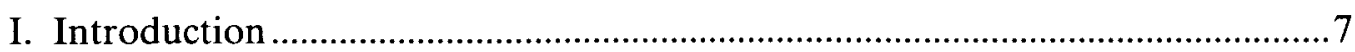

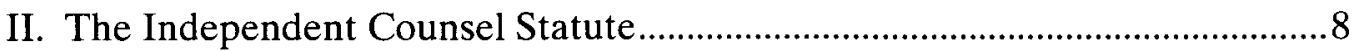

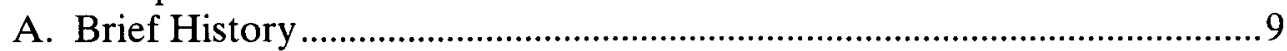

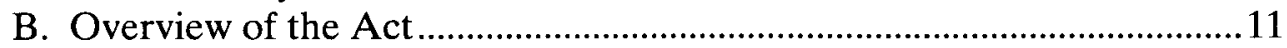

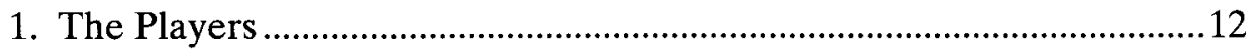

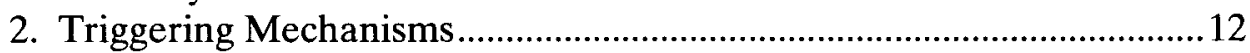

a. Covered persons......................................................................................

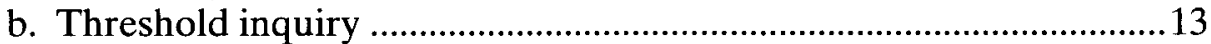

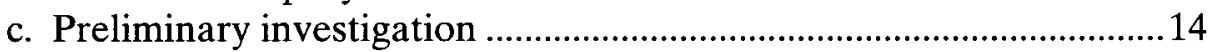

d. Triggering of the Act by Congress..........................................................14

e. Other issues at the triggering stage .....................................................15

3. Appointment of an Independent Counsel.............................................15

a. Application by the Attorney General ..................................................15

b. Special Division appointment and jurisdiction-defining

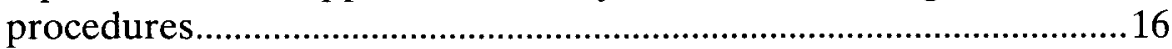

c. Other issues in independent counsel appointment ...............................17

4. The Independent Counsel .....................................................................17

a. Investigative and prosecutorial powers ..................................................17

b. Relationship with the Department of Justice and Congress .............17

c. Conclusion of the independent counsel's investigation.......................18

d. Other issues regarding the independent counsel ..................................18

5. Miscellaneous Statutory Provisions.......................................................19

6. Important Issues Not Addressed in the Act..........................................20

III. Analysis of the Triggering Provisions ............................................................21

A. Scope of the Categories of Covered Persons...........................................21

1. Mandatory Covered Persons......................................................................22

2. Discretionary Covered Persons .................................................................23

3. Conclusions on the Range of Covered Persons ......................................24

Copyright $@ 1999$ by Law and Contemporary Problems

This article is also available at http://www.law.duke.edu/journals/62LCPPriester.

* J.D., December 1998, Duke University School of Law.

** J.D., 1999, Duke University School of Law.

*** J.D. candidate, May 2000, Duke University School of Law.

The authors would like to thank Christopher Schroeder and Michael Treisman for their assistance in the preparation of this article. 


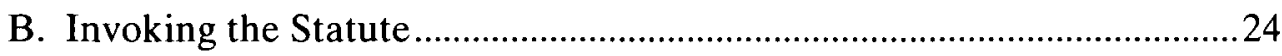

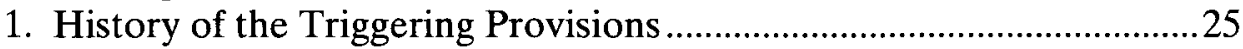

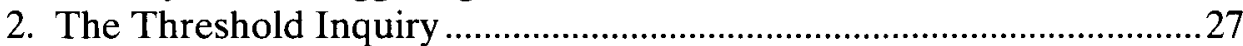

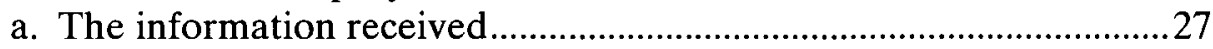

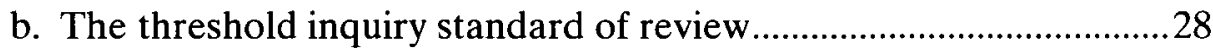

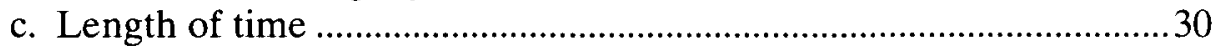

3. The Preliminary Investigation ................................................................. 30

a. The preliminary investigation standard of review ………………........30

b. Limitations on the preliminary investigation review …………….......32

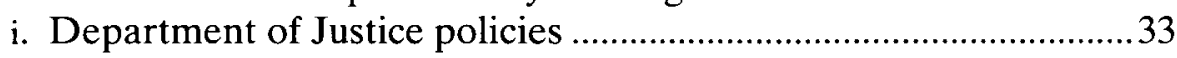

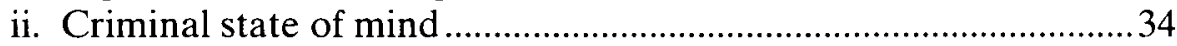

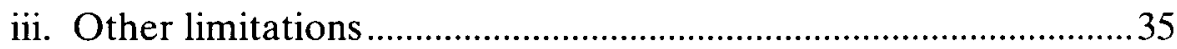

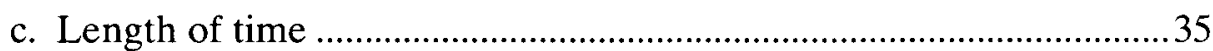

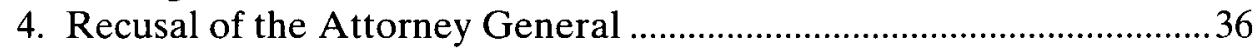

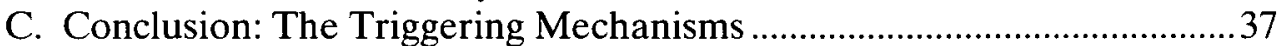

IV. Relationships Created and Altered by the Operation of the Act................38

A. The Relationship Between the Act and Private Citizens .........................38

1. Private Citizens Cannot Compel the Attorney General to Conduct a Preliminary Investigation .......................................................38

2. Private Citizens Cannot Compel the Special Division to Appoint an Independent Counsel .............................................................4 4

B. The Relationships Between the Act and the Special Division ................42

1. The Appointment and Selection of Independent Counsels by

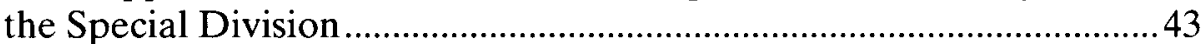

2. Defining the Independent Counsel's Jurisdiction .................................45

a. Expansion of the independent counsel's jurisdiction ..........................46

b. The referral of other matters to an independent counsel ..................47

3. The Termination of the Independent Counsel by the Special

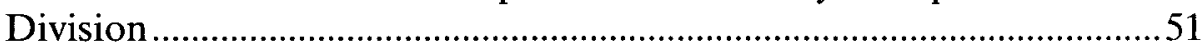

C. The Relationships Between the Independent Counsel and the

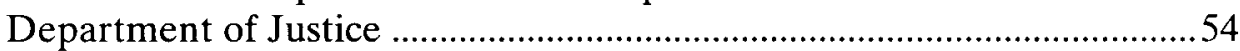

1. "All investigative and prosecutorial functions of the Department of Justice and the Attorney General."..............................54

2. Cooperation Between the Independent Counsel and DOJ .................55

3. The Independent Counsel's Compliance with Written or Other Established Policies of DOJ to the Extent the Policies are Not

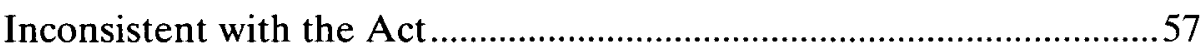

4. The Classified Information Procedures Act..........................................59

5. Removal of the Independent Counsel ..................................................63

D. The Relationship Between the Independent Counsel and Congress ....64

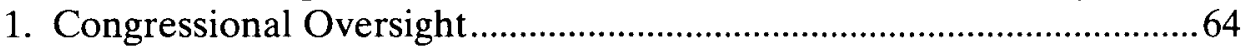

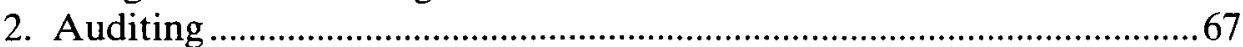

3. Parallel Congressional Investigations .....................................................6 68

4. The Impeachment Process..................................................................... 70 
E. Use of Grand Jury Materials ............................................................. 72

F. Conclusion: Relationships Created and Altered by the

Operation of the Act....................................................................... 73

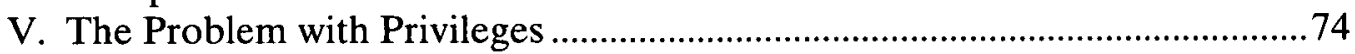

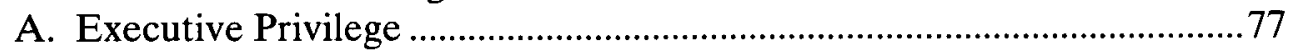

1. History of the Executive Privilege..................................................... 77

2. The Nature of Executive Privilege: United States v. Nixon ..................79

3. Subsequent Cases Involving Claims of Executive Privilege................81

a. The Reagan years...................................................................... 81

b. In re Sealed Case, June 1997 ............................................................8 82

c. In re Grand Jury Proceedings, May 1998 .......................................... 84

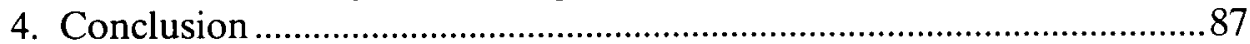

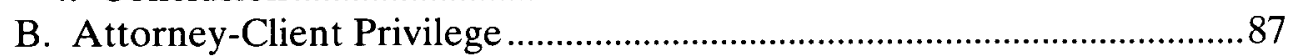

1. The History of Attorney-Client Privilege...........................................8 87

2. Special Problems Concerning a Governmental Attorney-Client Privilege ........................................................................................... 88

a. Watergate and the Iran-Contra Affair ........................................... 90

b. In re Grand Jury Subpoena Duces Tecum, April 1997..................... 91

d. In re Bruce R. Lindsey, 1998........................................................ 95

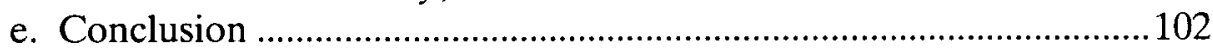

3. Problems with the Work-Product Doctrine .................................... 102

C. The Protective Function Privilege........................................................ 103

1. History of the Protective Function Privilege...................................103

2. Problems with Recognizing the Protective Function Privilege.......... 103

3. In Re Grand Jury Proceedings, May 1998 / In re Sealed Case, July 1998 ................................................................................... 105

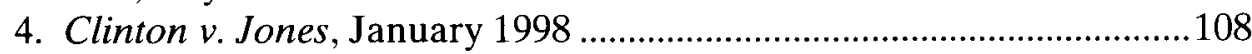

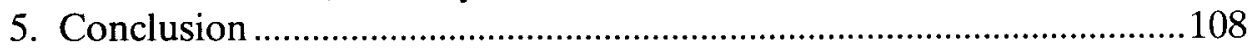

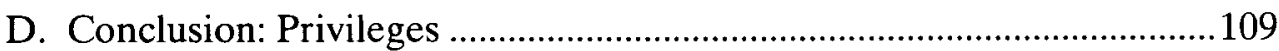

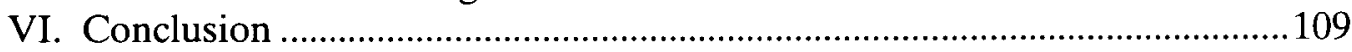

\section{I}

\section{INTRODUCTION}

The independent counsel statute ${ }^{1}$ has been one of the most-if not the most-controversial federal laws of its time. A presence on the national stage for twenty years, it will expire on June 30, 1999, ${ }^{2}$ unless Congress affirmatively acts to save it. As the other articles in this issue of Law and Contemporary Problems attest, the statute's future seems bleak, perhaps even if substantial

1. See 28 U.S.C. $\$ \S 591-599$ (1994).

2. See id. $\S 599$ (providing that the Act will expire five years after the enactment of the Independent Counsel Reauthorization Act of 1994, Pub. L. No. 103-270, 108 Stat. 732, which was enacted on June 30, 1994). 
revisions are made. Numerous other sources also have heaped praise, criticism, and everything in between upon the statute. A law with so dark a beginning and so storied a political history may be doomed to extinction.

Among all of the political upheaval over the independent counsel statute since its enactment, politicians, legal scholars, and laypersons alike often cannot help but lose sight of one aspect of the statute that has remained unchanged-it is a statute that, like any other, generates law by its existence and through its interpretation. Unlike the other currently available sources on the statute, this article is not a normative critique of the law, a review of the politics surrounding the statute, or a history of investigations under the statute. Instead, it provides a comprehensive legal history of the independent counsel statute from its inception in 1978 until its apparent last hurrah in 1999. The article's purpose, therefore, is to set forth the law that the statute has created, but to allow others to evaluate for themselves the merits of the statute and the praises and criticisms of it in this volume and elsewhere.

The article proceeds in four parts. Part II briefly summarizes the history of the statute and outlines its current provisions. Part III analyzes the statute's triggering mechanisms, the procedures by which an independent counsel appointment is or is not made. Part IV addresses the complex relationships between an independent counsel and other relevant actors in the political system: the public, the "Special Division of the Court" that oversees independent counsel investigations, the Attorney General and the Department of Justice, and Congress. Part V focuses on a specific legal issue of great importance to the statute's past and future: the role of the independent counsel in the history and practice of the government's evidentiary privileges, including the attorneyclient privilege and the President's executive privilege.

\section{II}

\section{THE INDEPENDENT COUNSEL STATUTE}

A central question of representative democracy is whether the government can be trusted. The independent counsel statute, officially the Ethics in Government $\mathrm{Act}^{3}$ (the "Act"), has served for twenty years as the answer to a more specific version of this question, a version even more specific than whether the government can be trusted to investigate itself. The question, which is at the core of this symposium, strikes at the heart of the executive branch of our constitutional system: Can the Attorney General and the Department of Justice ("DOJ") be trusted to investigate and prosecute criminal wrongdoing by the President or persons close to him? The Act demonstrates that our political leaders have concluded that the answer is "no."

The Act was intended to provide a mechanism by which certain investigations of allegations of misconduct by high-level political officials could be un-

3. Pub. L. No. 95-521, tit. VI, 92 Stat. $1824,1867-73$ (1978) (codified as amended at 28 U.S.C. § 591-599 (1994)). 
dertaken by a prosecutor whose activities are outside the President's direct supervision. Congress's goal was "to establish 'a neutral procedure for resolving the conflict of interest that arises when the Attorney General must decide whether to pursue allegations of wrongdoing leveled against . . . [his] close political associates.",4 The statute's tumultuous history and the evolution of its provisions, however, have demonstrated the elusiveness of achieving this purpose in practice.

\section{A. Brief History}

The tragedy of Watergate inspired the creation of a permanent statutory scheme for appointing an officer, independent from the supervision and control of the President, to investigate and prosecute crimes by high-level federal officials. ${ }^{5}$ President Nixon's misconduct, of course, prompted calls for greater scrutiny of high-level government officials generally. In addition, a particular episode during the Watergate period-the "Saturday Night Massacre"reinforced the principle that criminal investigations of the President or persons close to him must be handled by an officer with political independence. Before the "Massacre" occurred, Nixon had become convinced that Archibald Cox, the "special prosecutor" appointed by Attorney General Elliott Richardson to investigate the scandal, was not an impartial investigator, but rather a partisan prosecutor bent on bringing Nixon down. ${ }^{6}$ Nixon insisted that Cox be fired, but Richardson and Deputy Attorney General William Ruckelshaus each resigned rather than carry out the order; third-in-line Robert Bork was then appointed Acting Attorney General and promptly fired Cox on October 23, 1973. The dismissal of Cox caused the Senate and House Judiciary Committees to hold hearings on whether legislation was necessary to give special prosecutors a statutory guarantee of independence. ${ }^{8}$ To head off this inquiry, Leon Jaworski was quickly appointed as a new special prosecutor to continue the Watergate

4. Dellums v. Smith, 797 F.2d 817, 820 (9th Cir. 1986) (quoting Banzhaf v. Smith, 737 F.2d 1167, 1168 (D.C. Cir. 1984), and citing Special Prosecutor Provisions of Ethics in Government Act of 1978: Hearings Before Subcomm. on Oversight of Gov't Mgt. of the Sen. Comm. on Govt'l Affairs, 97th Cong. 1-3 (1981) (statement of Sen. Cohen) [hereinafter 1981 Senate Hearings]).

5. See generally KATY J. HARRIGER, INDEPENDENT Justice: ThE FEDERAL SPECIAL PROSECUTOR IN AMERICAN POLITICS 40-72 (1992); see also S. REP. No. 103-101, at 5-8 (1993), reprinted in 1994 U.S.C.C.A.N. 748, 748-52 (discussing the Watergate scandal as the impetus for enacting the Act); S. REP. No. 100-123, at 1-3 (1987), reprinted in 1987 U.S.C.C.A.N. 2150, $2150-52$ (same). A full discussion of Watergate itself is beyond the scope of this article; many fine sources on the events exist, including one by the special prosecutor. See LEON JAWORSKI, THE RIGHT AND THE POWER: The Prosecution of Watergate (1976); Watergate Special Prosecution Force, Final REPORT (1977). Other interesting sources include RICHARD BEN-VENISTE \& GEORGE FRAMPTON,

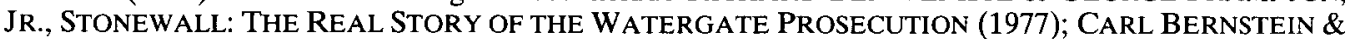
Bob WoOdWard, All the PREsident's Men (1974); JAMEs DoYle, Not Abové THE LAW: THE Battles of Watergate Prosecutors CoX and JAWORSki (1977); Ken Gormley, ARCHIBALd COX: CONSCIENCE OF A NATION (1997). ments).

6. Cf. HARRIGER, supra note 5 , at 42 (discussing the pre-Saturday Night Massacre develop-

7. See id.

8. See id. at 29,43 . 
investigation; Congress ceased its discussions after it determined that Jaworski was both de facto independent from Nixon and doing his job well. ${ }^{9}$

Although future special prosecutors might be able to replicate Jaworksi's success, many Americans believed that only statutory independence could prevent another Saturday Night Massacre. By 1978, therefore, Congress concluded that legislation was in fact necessary to restore public confidence in government. ${ }^{10}$ The outcome was Title VI of the Ethics in Government Act of $1978,{ }^{11}$ which established for the first time in the United States a codified structure for the appointment of an independent officer-first called a "special prosecutor," then renamed an "independent counsel"12 - in future scandals.

The enactment of a statutory procedure was not the only possible outcome of the Watergate scandal. DOJ argued-and continues to argue-that it can adequately investigate and prosecute almost every case of criminal wrongdoing by federal officials, even those near to the President; in situations where a significant conflict of interest exists, the Attorney General could and would choose voluntarily to appoint an $a d$ hoc special prosecutor. ${ }^{13}$

Several previous scandals involving the President or his close associates had resulted in ad hoc appointments by Attorneys General of "special prosecutors," including the Teapot Dome scandal in the Harding Administration, the 1951-52 tax scandals in the Truman Administration, and the appointments of Archibald Cox and Leon Jaworski in Watergate itself. ${ }^{14}$ In fact, some observers asserted that the success of the Watergate special prosecutors, who forced the resignation of the President and obtained several high-level convictions, proved that the system worked without any statutory structure. ${ }^{15}$ In the end, however, Congress concluded that relying solely on the Attorney General's integrity and on political pressures would not be the sufficiently visible action needed to restore the post-Watergate public's faith in government. ${ }^{16}$

9. See id. at $29-30,43$.

10. See id. at 43-44; see also S. REP. No. 95-170, at 2-4 (1977), reprinted in 1978 U.S.C.C.A.N. 4216, 4218-20 (reviewing the history preceding the Act's enactment); id. at 5-7, reprinted in 1978 U.S.C.C.A.N. at 4221-23 (summarizing the purposes of the Act).

11. Ethics in Government Act, Pub. L. No. 95-521, tit. VI, 92 Stat. 1824, 1867-73 (1978).

12. This change in title was made in the 1983 amendments to the Act. See Pub. L. No. 97-409, \$2, 96 Stat. 2039, 2039 (1983). Congress believed that the label "independent counsel" had less negative connotation: "This change would remove the Watergate connotation of a special prosecutor investigation and would help spare the subject of such investigation adverse public reaction." S. REP. NO. 97496 , at 19-20 (1982), reprinted in 1982 U.S.C.C.A.N. 3537, 3555-56.

13. See Dellums v. Smith, 797 F.2d 817, 820 (9th Cir. 1986) (citing testimony of Associate Attorney General Rudolph W. Guiliani in 1981 Senate Hearings, supra note 4, at 92-94, and Ethics in Government Act Amendments of 1982: Hearings on S. 2059 Before the Subcomm. on Oversight of Gov't Mgt. of the Sen. Comm. on Govt'l Affairs, 97th Cong. 5-7 (1982)).

14. See HARRIGER, supra note 5, at 13-39 (discussing pre-1978 ad hoc appointments of special prosecutors); Jerome J. Shestack, Foreword: The Independent Counsel Act Revisited, 86 GEO. L.J. 2012, 2012-13 (1998) (same).

15. See HARRIGER, supra note 5 , at 53.

16. This position also was advocated by the highly influential American Bar Association, which issued reports strongly urging Congress to reject the ad hoc appointment system in favor of a mandatory statutory scheme that would "trigger" the appointment of an independent prosecutor in appropriately defined cases. See id. at $49,62-64$. 
The Ethics in Government Act of 1978 was only the first generation of the statutory independent prosecutor scheme. Congress reviewed, debated, and revised the statutory procedures in $1983,{ }^{17} 1987,{ }^{18}$ and $1994 .{ }^{19}$ During the deliberation of each round of amendments, Congress reviewed the successes and failures of the Act, ${ }^{20}$ only to conclude that renewing the Act, with amendments, was the best outcome. Even a President who later found himself subject to the $\mathrm{Act}^{21}$ agreed with its necessity:

This law, originally passed in 1978, is a foundation stone for the trust between the Government and our citizens. It ensures that no matter what party controls the Congress or the executive branch, an independent, nonpartisan process will be in place to guarantee the integrity of public officials and ensure that no one is above the law.

Regrettably, this statute was permitted to lapse when its reauthorization became mired in a partisan dispute in the Congress. Opponents called it a tool of partisan attack against Republican Presidents and a waste of taxpayer funds. It was neither. In fact, the independent counsel statute has been in the past and is today a force for Government integrity and public confidence. ${ }^{22}$

The current version of the Act is the product of the persons, ${ }^{23}$ events, and scandals that shaped and reshaped the text and its procedures and provisions into their current form.

\section{B. Overview of the Act}

The Act provides the procedures for beginning, operating, and concluding an investigation by an independent counsel. The most detail is provided in the Act's procedural mechanisms, particularly in those that trigger the application of the Act, but other important topics also are addressed. The Act, at least in

17. See Ethics in Government Act Amendments of 1982, Pub. L. No. 97-409, 96 Stat. 2039 (1983).

18. See Independent Counsel Reauthorization Act of 1987, Pub. L. No. 100-191, 101 Stat. 1293.

19. See Independent Counsel Reauthorization Act of 1994, Pub. L. No. 103-270, 108 Stat. 732.

20. See S. REP. NO. 97-496, at 3-4 (1982), reprinted in 1982 U.S.C.C.A.N. 3537, 3539-40 (summarizing Congress's views of the Act after four years); S. REP. NO. 100-123, at 5-14 (1987), reprinted in 1987 U.S.C.C.A.N. 2150, 2154-63 (discussing successes and failures of the Act for its first nine years); S. REP. No. 103-101, at 10-23 (1993), reprinted in 1994 U.S.C.C.A.N. 748, 754-68 (reviewing the pros and cons of the Act after 15 years).

Congress also examined the operation of the Act in practice. See generally S. REP. NO. 103-101, at 1-9 (1993), reprinted in 1994 U.S.C.C.A.N. 748, 748-53 (reviewing the history and operation of the Act). See also S. REP. No. 100-123, at 6-8 (1987), reprinted in 1987 U.S.C.C.A.N. 2150, 2155-57 (reviewing independent counsel investigations from 1978-87); S. REP. NO. 103-101, at 12-13 (1993), reprinted in 1994 U.S.C.C.A.N. 748, 756-57 (reviewing independent counsel investigations from 198794); id. at 13-14, reprinted in 1994 U.S.C.C.A.N. at 757-58 (summarizing the outcome of each independent counsel investigation from 1978-94).

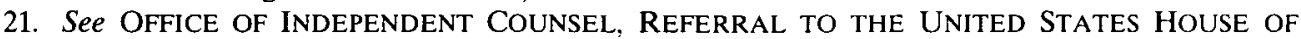

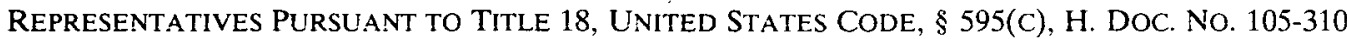
(Sept. 9, 1998), reprinted in THE STARR REPORT: THE INDEPENDENT COUNSEL'S COMPLETE REPORT TO CONGRESS ON THE INVESTIGATION OF PRESIDENT ClinTON (Pocket Books 1998) [hereinafter STARR REPORT].

22. Statement by President William J. Clinton upon Signing S. 24 [Independent Counsel Reauthorization Act of 1994, Pub. L. No. 103-270, 108 Stat. 732], 30 WKLY. COMP. PRES. DoC. 1383 (July 4, 1994).

23. In a notable and amusing coincidence, the Duke University School of Law graduated the Act's impetus-Richard M. Nixon, class of 1938-and one of its most prominent appointments-Kenneth W. Starr, class of 1973. 
general terms, attempts to resolve most issues that will arise when an independent counsel investigation is appropriate.

1. The Players. The Act cannot be understood without first identifying the principal actors in the statutory scheme. The identity of several actors is obvious; they are ordinary federal government institutions. These include the President, Congress, the Attorney General, and DOJ. The independent counsel, of course, is the investigator and prosecutor whose office is created and defined by the Act. Finally, however, one important actor was created specifically for the purposes of this particular Act. The "Special Division of the Court" is a three-judge panel of the United States Court of Appeals for the District of Columbia Circuit, appointed by the Chief Justice of the U.S. Supreme Court. ${ }^{24}$ Each of these actors, including the unusual Special Division, has critical functions in the Act's process.

\section{Triggering Mechanisms.}

a. Covered persons. The Act does not apply to every federal criminal investigation. Instead, its coverage is "triggered" only in certain situations. The first important limit is the Act's restriction to only two categories of persons: mandatory covered persons and discretionary covered persons. ${ }^{25}$ Application is limited to these two categories to achieve the Act's overall purpose: to investigate allegations of criminal conduct in those situations where investigation by the Attorney General or DOJ does or could give rise to a conflict of interest.

Mandatory covered persons include those individuals for whom a conflict of interest is presumed to exist by virtue of the close relationship or connection of the persons to the President, Attorney General, or DOJ. The Act requires that an independent counsel be appointed to undertake any and every investigation of such a person. Such mandatory coverage encompasses the President and Vice President, the Cabinet, the Executive Office of the President, and highlevel officials in DOJ, the CIA, the IRS, and the President's national election campaign. $^{26}$

Discretionary coverage, by contrast, allows the Attorney General to request an independent counsel appointment to investigate in situations where the conflict of interest is not presumed by the Act, but where an independent investigation nevertheless is appropriate. Such discretionary coverage is available for Members of Congress when appointing an independent counsel is "in the public interest,"

24. See 28 U.S.C. $\$$ 593(a) (1994) (providing for the appointment of the Act's Special Division court under the terms of 28 U.S.C. $\$ 49)$

25. See id. $\$ 591(\mathrm{~b})-(\mathrm{c})$.

26. See id. $\$ 591(\mathrm{~b})(1)-(7)$.

27. Id. $\S 591(\mathrm{c})(2)$. 
investigation or prosecution of [that] person by [DOJ] may result in a personal, financial, or political conflict of interest. ${ }^{, 28}$

$b$. Threshold inquiry. The Act is triggered in the first instance when the Attorney General "receives information sufficient to constitute grounds to investigate" ${ }^{29}$ whether a covered person has committed a serious federal crime. ${ }^{30}$ The Attorney General need not take this received information at face value, however, when deciding whether grounds to investigate exist. Instead, the Attorney General may also consider only two other factors: ${ }^{31}$ the specificity of the information and the credibility of its source. ${ }^{32}$ After receiving the information, the Attorney General has thirty days to determine whether to proceed further. ${ }^{33}$ It is significant, however, that the Act does not require the Attorney General to make any reports to the Special Division at this stage; the Attorney General's threshold inquiry determination is not reviewed by any other actor.

If the information is either not credible or not specific, the Attorney General "shall close the matter.", If, on the other hand, the Attorney General finds that the information is specific and credible, or is unable to make a conclusive determination either way, then he or she is bound to make a determination that sufficient grounds for investigation do exist, and thus "shall . . commence a preliminary investigation," ${ }^{35}$ which is the next stage of the Act's triggering mechanisms. Each time the Attorney General begins a preliminary investigation, he or she must "promptly notify" the Special Division. ${ }^{36}$

The Act also provides that the Attorney General must consider-in each and every investigation-before any action is taken even at the initial triggering stages-whether the Act requires his or her recusal from the statutory process. ${ }^{37}$ The Attorney General must recuse him- or herself when the allegations involve the Attorney General directly or any person "with whom the Attorney General has a personal or financial relationship." ${ }^{38}$ The Attorney General must file a report with the Special Division stating the recusal determination and the

28. Id. $\S 591(\mathrm{c})(1)$.

29. Id. $\S 591(\mathrm{a})$.

30. See id. (defining such a violation as "any Federal criminal law other than a violation classified as a Class B or C misdemeanor or an infraction").

31. See id. \& 591(d)(1) ("[T]he Attorney General shall consider only_" specificity and credibility.) (emphasis added); id. § 592(a)(2)(B)(i) (forbidding Attorney General from considering whether accused had required mens rea for crime when finding that the received information is not specific or credible).

32. See id. $\S 591(d)(1)$.

33. See id. § 591(d)(2).

34. Id.

35. Id.

36. Id. $\S 592(\mathrm{a})(1)$.

37. See id. $\$ 591(\mathrm{e})(2)$ ("Before personally making any other determination under this chapter, the Attorney General shall determine ... whether recusal is necessary.").

38. Id. $\S 591(\mathrm{e})(1)$. 
reasons for or against recusal. ${ }^{39}$ If the Attorney General recuses him- or herself, the next most senior DOJ official who is not also recused under the same standard then performs the Attorney General's functions under the Act. ${ }^{40}$

c. Preliminary investigation. The purpose of the preliminary investigation is to determine whether there are "reasonable grounds to believe that further investigation is warranted." ${ }^{, 41}$ If there are such grounds, an independent counsel will be appointed to perform that further investigation; if there are not such grounds, an independent counsel will not be appointed. Given that the Attorney General already has specific and credible evidence of a federal crime by a covered person, the independent counsel appointment provisions usually will come into play.

The scope of the preliminary investigation is constrained by the Act. First, the Act bars the Attorney General from using several prominent investigative techniques: The Attorney General may not use a grand jury or issue subpoenas, and may not grant immunity or make plea bargains. ${ }^{42}$ Second, the Act prohibits the Attorney General from "bas[ing] a determination ... that there are no reasonable grounds to believe that further investigation is warranted[] upon a determination that [the accused] lacked the state of mind required for violation of criminal law involved, unless there is clear and convincing evidence" ${ }^{, 43}$ that the accused lacks the necessary mens rea. Third, the Act requires the Attorney General to obey DOJ's standard criminal investigation policies. ${ }^{44}$ Finally, the preliminary investigation may last only ninety days ${ }_{46}^{45}$ although the Special Division may grant a sixty-day extension for good cause. ${ }^{46}$

If the Attorney General finds no reasonable grounds to warrant further investigation, he or she must notify the Special Division. ${ }^{47}$ If the Attorney General finds that further investigation is warranted, or the time period elapses without a contrary filing, then he or she must apply to the Special Division for the appointment of an independent counsel to commence further investigation on behalf of the government. ${ }^{48}$

d. Triggering of the Act by Congress. The Judiciary Committee of either chamber of Congress, or a majority of either the majority or the nonmajority party members on the Committee, may request that the Attorney General

39. See id. $\$ 591(\mathrm{e})(2)$.

40. See id. $\$ 591(\mathrm{e})(1)$.

41. Id. §592(c)(1)(A); $f . i d . \S 592(\mathrm{a})(1)$.

42. See id. \&592(a)(2)(A).

43. Id. $\S 592(\mathrm{a})(2)(\mathrm{B})(\mathrm{ii}) ; c f$. id. $\S 592(\mathrm{a})(2)(\mathrm{B})(\mathrm{i})$ (forbidding Attorney General from considering state of mind at threshold inquiry stage).

44. See id. $\$ 592$ (c)(1)(B) ("[T]he Attorney General shall comply with the written or other established policies of the Department of Justice with respect to the conduct of criminal investigations.").

45. See id. $\$ 592(\mathrm{a})(1)$.

46. See id. $\$ 592(\mathrm{a})(3)$.

47. See id. $\$ 592(\mathrm{~b})$.

48. See id. $\S 592(\mathrm{c})(1)(\mathrm{A})-(\mathrm{B})$. 
invoke the Act to appoint an independent counsel. ${ }^{49}$ The Act's triggering mechanisms then function as they do with any other receipt of information, with three modifications: (1) when the threshold inquiry is completed ("[n]ot later than 30 days after the receipt of" the congressional request), the Attorney General must file a report with the Committee explaining the reasons why a preliminary investigation will or will not commence, ${ }^{50}(2)$ if a preliminary investigation occurs, copies of all papers from that investigation filed with the Special Division also must be given to the Committee, ${ }^{51}$ and (3) if the Attorney General declines to apply for the appointment of an independent counsel after the preliminary investigation, the Attorney General must file a report to the Committee "stating the reasons why such application was not made, addressing each matter with respect to which the congressional request was made." ${ }^{52}$ The Act attempts to protect suspects by declaring that information given to the Committee under these requirements "shall not be revealed to any third party" unless the Committee determines that a disclosure "will not... prejudice the rights of any individual." ${ }^{53}$ In practice, the principal significance of this congressional request procedure has been the generation of many of the Attorney General's official position statements on various interpretations of the Act. ${ }^{54}$

$e$. Other issues at the triggering stage. The Act also contains provisions addressing several minor issues that may arise at the triggering stage. If the Attorney General receives new information related to a crime about which he or she already has reported to the Special Division, the process starts anew. ${ }^{55}$ The Act also provides that the Attorney General's decision to request or not to request the appointment of an independent counsel by the Special Division "shall not be reviewable in any court."

\section{Appointment of an Independent Counsel.}

a. Application by the Attorney General. The process of appointing an independent counsel begins with the filing of an application by the Attorney General with the Special Division. The application "shall contain sufficient information to assist [the Special Division] in selecting an independent counsel and in defining that independent counsel's prosecutorial jurisdiction ... to fully

49. See id. §592(g)(1).

50. Id. $\S 592(\mathrm{~g})(2)$.

51. See id. $\$ 592(\mathrm{~g})(3)$.

52. Id.

53. Id. $\S 592(\mathrm{~g})(4)$.

54. See, e.g., Letter from Janet Reno, Attorney General of the United States, to Orrin G. Hatch, Chairman, United States Senate Committee on the Judiciary (Apr. 14, 1997), cited in Orrin G. Hatch, The Independent Counsel Statute and Questions About Its Future, 62 LAW \& CONTEMP. PROBS. 145, 151 n.36 (Winter 1999).

55. See 28 U.S.C. $\$ 592(c)(2)(1994)$.

56. See id. \&592(f). 
investigate and prosecute the subject matter" and related matters. ${ }^{57}$ The Act also provides that, absent the permission of the Special Division, the application and its contents may not be disclosed to the public by DOJ or by an independent counsel. ${ }^{58}$

b. Special Division appointment and jurisdiction-defining procedures. The Special Division selects and appoints the independent counsel to investigate the allegations referred by the Attorney General. ${ }^{59}$ The Act directs the Special Division to consider experience, responsibility, cost-efficiency, and promptness in selecting an independent counsel.

The Special Division also defines the scope of the independent counsel's jurisdiction to investigate and prosecute. ${ }^{61}$ The scope includes "the subject matter with respect to which the Attorney General has requested the appointment of the independent counsel, and all matters related to that subject matter," and any federal crimes "that may arise out of the investigation or prosecution" of that subject matter (such as perjury, obstruction of justice, destruction of evidence, or witness tampering).

If the jurisdiction of an independent counsel needs to be expanded beyond the original mandate, the Special Division lacks the authority to make such an extension alone. Instead, the Act provides that an independent counsel's jurisdiction may be expanded only at the request of the Attorney General. ${ }^{63}$ If the independent counsel uncovers information unrelated to the scope of the original jurisdiction but nonetheless warranting further investigation, the independent counsel may forward this information to the Attorney General, who then follows a preliminary investigation procedure under the Act; ultimately, the Attorney General will request or decline to request the Special Division to transfer the investigation of this new information to the jurisdiction of an independent counsel. $^{64}$ (The Special Division may expand the jurisdiction of an existing independent counsel instead of appointing a new independent counsel to handle the new subject matter. ${ }^{65}$ ) On the other hand, if the new information found by the independent counsel is related to the independent counsel's existing jurisdiction, the further investigation of that related information may be referred to the independent counsel by the Attorney General or by the Special Division as a matter of course. ${ }^{66}$

57. $I d . \S 592(\mathrm{~d})$.

58. See id. $\S 592(\mathrm{e})$. This subsection also provides exceptions for disclosures to Congress and "as is deemed necessary for law enforcement purposes." Id.

59. See id. §593(b)(1).

60. See id. $\S 593(\mathrm{~b})(2)$.

61. See id. § 593(b)(1), (3).

62. Id. $\S 593(\mathrm{~b})(3)$.

63. See id. $\S 593(\mathrm{c})(1)$.

64. See id. $\$ 593(\mathrm{c})(2)(\mathrm{A})-(\mathrm{C})$.

65. See id. \& 593(c)(1).

66. See id. § 594(e). 
c. Other issues in independent counsel appointment. The Special Division has several other powers relating to the appointment of an independent counsel. The court is permitted to keep the identity and jurisdiction of the independent counsel secret, with certain exceptions, ${ }^{6 /}$ but the court also may allow the public disclosure of any filings before it. ${ }^{68}$ The Special Division also fills vacancies in the office of an independent counsel. ${ }^{69}$ Finally, the court may permit the filing of briefs amicus curiae on "significant legal issues" that arise in the pursuit of its statutory duties. ${ }^{70}$

\section{The Independent Counsel.}

a. Investigative and prosecutorial powers. An independent counsel, within the jurisdiction defined by the Special Division, has "full power and independent authority to exercise all investigative and prosecutorial functions and powers of" DOJ and the Attorney General. ${ }^{71}$ The Act's list of powers includes convening grand juries, granting immunity, prosecuting, litigating, and appealing in federal court, reviewing evidence and contesting privilege assertions, obtaining security clearances, and other powers. ${ }^{72}$ An independent counsel also may dismiss matters within his or her jurisdiction before prosecution or even without investigation. ${ }^{73}$ In all activities, however, the independent counsel "shall . . comply with the written or other established policies of the Department of Justice respecting enforcement of the criminal laws." 74 This requirement is waived, however, "to the extent that doing so would be inconsistent with the purposes of [the Act].",

b. Relationship with the Department of Justice and Congress. The independent counsel is "separate from and independent of" DOJ. ${ }^{76}$ DOJ must cease any investigations of matters within the jurisdiction of the independent counsel. $^{74}$ The entities are not completely divided, however. The independent counsel may seek DOJ's assistance in pursuing the investigation, ${ }^{78}$ including the detailing of DOJ staff to the independent counsel ${ }^{79}$ or consulting with U.S.

67. See id. $\S 593($ b)(4). The independent counsel's identity and jurisdiction may be made public at the Attorney General's request or if the Special Division finds that disclosure "would be in the best interests of justice," and must be made public when an indictment or information is filed by the independent counsel. Id.

68. See id. $\$ 593(\mathrm{~g})$.

69. See id. $\$ 593(\mathrm{e})$.

70. $I d . \S 593(\mathrm{~h})$.

71. Id. \&594(a). An exception is made, however, for DOJ to retain control over requests to courts for authorizations for wiretaps and electronic surveillance. See id. (excepting 18 U.S.C. $\$ 2516$ (1994)).

72. See id. \$594(a)(1)-(10).

73. See id. $\$ 594(\mathrm{~g})$.

74. Id. $\S 594(\mathrm{f}) ; c f$. id. $\S 594(\mathrm{~g})$ (imposing a similar requirement on decisions to dismiss a matter).

75. $I d$.

76. Id. $\S 594(\mathrm{i})$.

77. See id. $\$ 597(\mathrm{a})$.

78. See id. § 594(d)(1).

79. See id. 
Attorneys. ${ }^{80}$ Likewise, DOJ may refer additional related matters to the independent counsel, ${ }^{81}$ and is guaranteed the right to appear as amicus curiae on issues of law raised in any independent counsel court proceeding. ${ }^{82}$

The Act also contains provisions relating to the independent counsel's relationship with Congress. The relevant committees are given oversight jurisdiction of the independent counsel ${ }^{83}$ and of the Attorney General's use of his powers under the Act ${ }^{84}$ the independent counsel also must report annually to Congress on his or her activities. ${ }^{85}$ Finally, the independent counsel is required to "advise the House of Representatives of any substantial and credible information ... that may constitute grounds for an impeachment., ${ }^{, 86}$

c. Conclusion of the independent counsel's investigation. When an independent counsel concludes his or her investigation and prosecution activities, the office of independent counsel is closed. There is no statutory limit on the independent counsel's length of service. The independent counsel's office is "terminated" when the independent counsel notifies the Attorney General of his or her completion and files a final report, ${ }^{87}$ or when the Special Division determines that the independent counsel's investigation has "been completed or so substantially completed that it would be appropriate for the Department of Justice to complete such investigations and prosecutions."

An independent counsel may be removed from office involuntarily by action taken by the Attorney General personally "and only for good cause." 89 The Attorney General must file a report to the Special Division and to Congress, ${ }^{90}$ and the independent counsel may seek judicial review of the removal. ${ }^{91}$ The independent counsel also may be removed from office involuntarily through impeachment and conviction by Congress. ${ }^{92}$

d. Other issues regarding the independent counsel. The Act provides for the independent counsel's pay ${ }^{93}$ and for hiring personnel. ${ }^{94}$ The costs incurred by the independent counsel's investigation are subject to reporting and

80. See id. § 594(a)(10).

81. See id. $\$ 594(\mathrm{e})$.

82. See id. $\$ 597(\mathrm{~b})$.

83. See id. §595(a)(1).

84. See id. $\$ 595(\mathrm{~b})$.

85. See id. § 595(a)(2).

86. Id. \&595(c).

87. See id. $\$ 596(\mathrm{~b})(1)$.

88. Id. $\S 596(\mathrm{~b})(2)$.

89. Id. §596(a)(1). The independent counsel also may be removed for several listed incapacities to perform the office, such as physical or mental disability. See id.

90. See id. § 596(a)(2).

91. See id. \$596(a)(3).

92. See id. §596(a)(1).

93. See id. $\$ 594(\mathrm{~b})$.

94. See id. $\$ 594(\mathrm{c})$. 
oversight requirements. ${ }^{95}$ When the office of the independent counsel is terminated, "all records which have been created or received by that office" are delivered to the National Archives. ${ }^{96}$ Finally, the Act includes conflict of interest requirements: During the independent counsel investigation, neither the independent counsel nor any of his or her assistants, nor persons associated with his or her law firm, may represent any person subject to an independent counsel investigation. ${ }^{97}$ After the independent counsel's office is terminated, the independent counsel and his or her assistants are barred for three years from any representation of their investigation's subjects ${ }^{98}$ and for one year from representation of any person subject to an independent counsel investigation; ${ }^{99}$ persons associated with the independent counsel's law firm are barred for one year from representing any subject of any independent counsel investigation. ${ }^{100}$

5. Miscellaneous Statutory Provisions. The Act provides some protection for subjects of independent counsel investigations against whom no charges are filed. At such person's request, the Special Division may award to the "subject of an investigation conducted by an independent counsel ... if no indictment is brought against such individual... reimbursement for those reasonable attorneys' fees incurred by that individual during that investigation which would not have been incurred but for" the independent counsel investigation. ${ }^{101}$ A list of factors for the Special Division to consider when deciding attorneys' fee requests is included. ${ }^{102}$ Special Division policy requires that all fee awards be made public. ${ }^{103}$ Not surprisingly, a considerable amount of litigation has proceeded under this provision. ${ }^{104}$ In addition, Congress has been troubled by

\footnotetext{
95. See id. $\$ 594(l)$ (cost controls); id. \$ 596(c) (Comptroller General audits).

96. Id. $\S 594(\mathrm{k})$.

97. See id. $\$ 594(\mathrm{j})(1)$.

98. See id. $\$ 594(\mathrm{j})(2)(\mathrm{A})$.

99. See id. $\S 594(\mathrm{j})(2)(\mathrm{B})$.

100. See id. $\$ 594(\mathrm{j})(3)$.

101. Id. $\$ 593(\mathrm{f})(1)$.

102. See id. $\$ 593(\mathrm{f})(2)(\mathrm{A})$-(D).

103. See Symposium, The Independent Counsel Process: Is It Broken and How Should It Be Fixed?, 54 WASH. \& LEE L. REV. 1515, 1543 (1997) (statement of Judge John Butzner, Jr.) (noting that the Special Division has a "firm rule" that it will not award attorneys' fees without making such an award public: "We have requests to do that. We have motions, 'Please don't make this request for fees public,' and we deny those motions.").

104. It is important to note that many of the cited cases apply the attorneys' fees provision prior to the 1994 amendments to $\S 593(f)$. For cases discussing whether an individual qualifies as a "subject" of an independent counsel investigation, see In re North, 120 F.3d 293 (D.C. Cir. 1997); In re North, 94 F.3d 685 (D.C. Cir. 1996); In re Mullins, 91 F.3d 1516 (D.C. Cir. 1996); In re Mullins, 84 F.3d 1439 (D.C. Cir. 1996); In re North, 74 F.3d 283 (D.C. Cir. 1996); In re North, 59 F.3d 184 (D.C. Cir. 1995); In re North, 57 F.3d 1117 (D.C. Cir. 1995); In re North, 56 F.3d 261 (D.C. Cir. 1995); In re North, 53 F.3d 1305 (D.C. Cir. 1995); In re North, 46 F.3d 1192 (D.C. Cir. 1995); In re North, 12 F.3d 252 (D.C. Cir. 1994); In re North, 11 F.3d 1082 (D.C. Cir. 1993); In re North, 8 F.3d 847 (D.C. Cir. 1993).

For cases holding that costs "would not have been incurred but for" an independent counsel investigation, see In re North, 57 F.3d 1115 (D.C. Cir. 1995); In re North, 33 F.3d 76 (D.C. Cir. 1994); In re North, 31 F.3d 1188 (D.C. Cir. 1994); In re North, 30 F.3d 143 (D.C. Cir. 1994); In re Meese, 907 F.2d 1192 (D.C. Cir. 1990); In re Olson, 884 F.2d 1415 (D.C. Cir. 1989); In re Donovan, 877 F.2d 982 (D.C. Cir. 1989). For examples of early cases holding that costs did not meet the "but for" requirement, see
} 
whether the attorneys' fees provision has the proper scope, but significant changes have not been made. ${ }^{10}$

Finally, the Act includes two mundane, yet interesting, procedural provisions. The severability clause aims to protect the architecture of the Act should any given provision be held invalid. ${ }^{106}$ The sunset provision ensures future legislative deliberation on the institution of the independent counsel in general and on the specific elements of the Act in particular by providing that the Act will expire five years from its enactment, although then-pending matters are preserved. ${ }^{107}$ The sunset provision will terminate the current version of the Act on June $30,1999 .{ }^{108}$

6. Important Issues Not Addressed in the Act. One of the Act's notable features is the absence of provisions that would resolve key issues that arise during independent counsel investigations. Of course, flaws in the Act can be revealed only through its operation. In large part, many of the modifications made to the Act in the three rounds of amendments were direct responses to gaps revealed during the Act's operation. Other issues, however, were not resolved by Congress despite the problems created by the Act's silence. For example, the Act does not define the character of the relationship between the independent counsel and the other offices and agencies in the executive branch in a manner that resolves intrabranch assertions of evidentiary privileges. ${ }^{109}$ The Act likewise lacks any provision on the implications of interbranch privilege claims in congressional investigations or impeachment hearings. ${ }^{110}$ The Act also is conspicuously silent on how the independent counsel is to handle sensitive matters with foreign policy or national security implications, ${ }^{11}$

In re Nofziger, 969 F.2d 1138 (D.C. Cir. 1992); In re Nofziger, 956 F.2d 287 (D.C. Cir. 1992); In re Nofziger, 938 F.2d 1397 (D.C. Cir. 1991); In re Nofziger, 925 F.2d 428 (D.C. Cir. 1991).

For cases discussing whether costs were incurred "during" an independent counsel investigation, see In re Mullins, 87 F.3d 1372 (D.C. Cir. 1996); In re North, 48 F.3d 1267 (D.C. Cir. 1995); In re North, 37 F.3d 663 (D.C. Cir. 1994); In re Sealed Case, 890 F.2d 451 (D.C. Cir. 1989).

For a case holding that fees were not "incurred" by the subject, see In re North, 32 F.3d 609 (D.C. Cir. 1994).

For cases discussing whether the amount of fees requested was "reasonable," see In re North, 72 F.3d 891 (D.C. Cir. 1995); In re North, 50 F.3d 42 (D.C. Cir. 1995); In re North, 32 F.3d 607 (D.C. Cir. 1994); In re Olson, 892 F.2d 1073 (D.C. Cir. 1990).

105. See, e.g., S. REP. No. 97-496, at 18-19, 22 (1982), reprinted in 1982 U.S.C.C.A.N. 3537, 3554-55, 3558 (discussing adoption of attorneys' fees provision); S. REP. NO. 100-123, at 21 (1987), reprinted in 1987 U.S.C.C.A.N. 2150, 2170 (proposing changes); H.R. CONF. REP. No. 100-452, at 30-31 (1987), reprinted in 1987 U.S.C.C.A.N. 2185 , $2196-97$ (discussing 1987 changes); S. REP. NO. 103-101, at 20-21 (1993), reprinted in 1994 U.S.C.C.A.N. 748, 765-66 (proposing more changes); H.R. CONF. REP. NO. 103-511, at 13-15 (1994), reprinted in 1994 U.S.C.C.A.N. 792, 796-98 (discussing 1994 changes).

106. See 28 U.S.C. $\$ 598$ (1994).

107. See id. \$ 599.

108. See id. The Independent Counsel Reauthorization Act of 1994, Pub. L. No. 103-270, 108 Stat. 732, was enacted on June 30, 1994.

109. See infra Part V.

110. Cf. infra text accompanying notes 618-619 (discussing possibility of conflicts over governmental attorney-client privilege during impeachment proceedings).

111. See Morrison v. Olson, 487 U.S. 654, 707-09 (1988) (Scalia, J., dissenting) (arguing that the Act is unconstitutional in part because it disturbs the President's ability to supervise the delicate balancing 
or whether classified information should be declassified in order to bring a prosecution. ${ }^{112}$ The Act was not amended to address these issues even after the Iran-Contra ${ }^{113}$ independent counsel investigation was substantially undermined by congressional immunity grants and the Attorney General's refusal to declassify defendants' information. ${ }^{114}$

\section{III}

\section{ANALYSIS OF THE TRIGGERING PROVISIONS}

The triggering provisions ${ }^{115}$ are critical components of the Act. They determine when-or if - the Act will require the appointment of an independent counsel to handle the government's investigation and prosecution in a particular case. Despite their importance, they have been developed through uncoordinated piecemeal amendments by Congress rather than the more careful construction required to ensure their effectiveness. When the initial triggering requirements were found to be troublesome, the Act was modified to correct the perceived problems. The difficulty, however, was that each new amendment created its own interpretive dilemmas, and that new problems arose with older, previously unmodified provisions. In the end, it is possible to understand the current Act's triggering mechanisms only by understanding the history of the Act and its practice, and how that history and practice shaped the language that now governs the triggering of an independent counsel investigation. The following sections of this Part of the article discuss the significant issues arising under the triggering provisions.

\section{A. Scope of the Categories of Covered Persons}

The most frequently modified element of the Act's triggering mechanisms is also one of the most important: which officials are covered by the Act. The purpose of the Act is to prevent public distrust of government by recognizing that "actual or perceived conflicts of interest may exist when the Attorney General is called on to investigate alleged criminal activities by high-level government officials." 116 It is critical, therefore, to identify which persons and positions are so close to the Attorney General or the President that permitting the

of interests necessary to foreign and national security policy, and citing examples such as an independent counsel who caused a significant foreign policy embarrassment by issuing a subpoena to the Canadian ambassador to the United States).

112. See infra Part IV.C.4 (discussing the Act's silence regarding the Classified Information Procedures Act).

113. "Iran-Contra" refers to the events surrounding the involvement of the U.S. government with the Nicaraguan Contras during a prohibition on military aid from October 1984 to October 1986. During this period, the government covertly directed funds to the Contras that were collected from the sale of arms to Iran. See 1 LAWRENCE E. WALSH, FINAL REPORT OF THE INDEPENDENT COUNSEL FOR IRAN/CONTRA MATTERS 1 (1993).

114. See infra notes $360-370,404-412$ and accompanying text.

115. See supra Part II.B.2.

116. S. REP. NO. 97-496, at 4 (1982), reprinted in 1982 U.S.C.C.A.N. 3537, 3540. 
Attorney General and DOJ to investigate them would be inappropriate. Defining the scope of this group has proven to be a difficult undertaking.

1. Mandatory Covered Persons. Some officials-the mandatory covered persons-are automatically included within the Act's scope. These are officials for whom the Act creates an irrebuttable presumption that a conflict of interest would exist were the Attorney General and DOJ to investigate allegations against them. The Act therefore provides that its procedures are triggered whenever the Attorney General receives criminal allegations about any such individual. ${ }^{117}$ Two principal issues must be decided to identify the officials that fall within this category: (1) which positions pose this presumed conflict of interest, and (2) for what period of time persons holding those positions should be covered.

Certain federal offices always have received mandatory coverage under the Act. These include the President and Vice President, ${ }^{118}$ Cabinet-level officers, ${ }^{119}$ high-level officials in the Executive Office of the President ${ }^{120}$ and in DOJ, ${ }^{121}$ and the Director and Deputy Director of the CIA and the IRS Commissioner. ${ }^{122}$ The list's unchanged scope signals Congress's conclusion that these positions continue to pose a conflict of interest with Attorney General and DOJ investigation.

The troublesome issue, however, has been calibrating the appropriate length of time persons holding these positions should be covered by the Act (and thus exposed to the possibility that an independent counsel could be appointed to investigate them). The 1978 Act provided coverage during the incumbency of the President under whom the person served, and the incumbency of the next President if of the same party. ${ }^{123}$ Congress concluded, however, that it was "unfair [to] hold[] an individual subject to the standards of a public servant long after he or she leaves office and long after the dangers of conflict of interest have passed. Equally unfair is the fact that coverage turns on which political party wins the presidential election." ${ }^{124}$ Based on this determination, the 1983 amendments limited coverage to the incumbency of the President plus one year (but not for more than two years after the person left his position), or to one year after the person left his position if he remained as a holdover in of-

117. See 28 U.S.C. $\$ 591(a)$ (1994).

118. See id. \$ 591(b)(1).

119. See id. $\$ 591(\mathrm{~b})(2)$.

120. See id. $\S 591$ (b)(3). In 1983, this category was reduced from those officials at pay level IV and higher to those at pay level II and higher. See Pub. L. No. 97-409, § 3, 96 Stat. 2039, 2039 (1983). Congress concluded that the 1978 scope had been too broad: "This coverage includes middle-level Executive Branch officials who are often unknown to the public, as well as remote from the Department of Justice and the President." S. REP. NO. 97-496, at 6 (1982), reprinted in 1982 U.S.C.C.A.N. 3537, 3542. Coverage was reduced from about 120 to about 70 positions. See id. at 7 , reprinted in 1982 U.S.C.C.A.N. at 3543 .

121. See 28 U.S.C. $\$ 591(b)(4)$.

122. See id. $\$ 591(\mathrm{~b})(5)$.

123. See Pub. L. No. 95-521, tit. VI, 92 Stat. 1824, 1868 (1978) (1978 version of $\S 591(b)(5)$ ).

124. S. REP. NO. 97-496, at 10 (1982), reprinted in 1982 U.S.C.C.A.N. 3537, 3546. 
fice more than ninety days into a new presidential administration. ${ }^{125}$ In 1987 , the post-employment coverage was extended to a three-year period; the holdover provision was unchanged. ${ }^{126}$ Finally, in 1994 , the term of coverage was shortened and greatly simplified: Any person holding one of these covered offices is covered during his service in office plus one year thereafter. ${ }^{127}$

One other category of persons also receives mandatory coverage: certain officials of the President's national election campaign. The 1978 provision allowed coverage for any officer of the President's principal national campaign committee, but did not specify a term of coverage. ${ }^{128}$ In 1983 , this group was reduced to the chairman, treasurer, and other officials with national campaign authority, with the campaign manager or director listed as examples. ${ }^{129}$ The term of coverage, which was specified as the incumbency of the President, ${ }^{130}$ has remained unchanged. ${ }^{131}$ The 1987 amendments deleted the reference to the campaign manager or director to avoid the implication that other national campaign officials might not be covered. ${ }^{132}$ The 1994 amendments made no changes to campaign official coverage. The mandatory coverage of the highest campaign officials for the President is now a solidly grounded statutory category.

2. Discretionary Covered Persons. The discretionary coverage of the Act is available for any person if the Attorney General concludes that a DOJ investigation or prosecution of that person "may result in a personal, financial, or political conflict of interest." 133 Discretionary coverage was added to the Act in 1983 to "provide a "catch-all' provision ... . [that] can be used to investigate private citizens who are close to either the President or the Attorney General as well as officials who are not covered under subsection 591(b)."134 The 1987 reauthorization law did not make substantial changes. Instead, it simply

clarifie[d] and simplifie[d] language ... to continue functioning as a "catchall" provision which gives the Attorney General the discretion to use the independent counsel

125. See Pub. L. No. 97-409, § 3, 96 Stat. 2039, 2040 (1983) (1983 version of $\S 591(b)(6)-(7))$.

126. See Pub. L. No. 100-191, 101 Stat. 1293, 1294 (1987) (amending $\$$ 591(b)(6)-(7)); see also H.R. CONF. REP. NO. 100-452, at 20 (1987), reprinted in 1987 U.S.C.C.A.N. 2185, 2186 (rejecting extension to five years proposed by S. REP. NO. 100-123, at 16 (1987), reprinted in 1987 U.S.C.C.A.N. 2150, 2165).

127. Thus, any reference to the incumbency of the President was deleted, as was the holdover provision. The only time reference is to the period the person held his or her office, nothing more. See Pub. L. No. 103-270, § 4(b), 108 Stat. 732, 736-37 (1994); S. REP. No. 103-101, at 26 (1993), reprinted in 1994 U.S.C.C.A.N. 748, 771; H.R. CONF. REP. NO. 103-511, at 9 (1994), reprinted in 1994 U.S.C.C.A.N. $792,792$.

128. See Pub. L. No. 95-521, tit. VI. 92 Stat. 1824. 1868 (1978) (1978 version of $\S 591(\mathrm{~b})(6)$ ).

129. See Pub. L. No. 97-409, § 3, 96 Stat. 2039, 2040 (1983) (amending $§ 591(b)(8)$ ).

130. See id.; see also S. REP. No. 97-496, at 8 (1982), reprinted in 1982 U.S.C.C.A.N. 3537, 3544 (stating that the conflict of interest for campaign officials ends with the incumbency of the President the person helped elect).

131. See 28 U.S.C. $\$ 591(b)(6)(1994)$.

132. See Pub. L. No. 100-191, 101 Stat. 1293, 1294 (1987) (1987 version of $\S 591(b)(8)$ ); H.R. CONF. REP. No. 100-452, at 20-21 (1987), reprinted in 1987 U.S.C.C.A.N. 2185, 2186-87.

133. 28 U.S.C. $\$ 591(\mathrm{c})(1)(1994)$.

134. S. REP. NO. 97-496, at 9 (1982), reprinted in 1982 U.S.C.C.A.N. 3537, 3545. 
process for any person not explicitly named in the Act as a covered official. This provision could apply, for example, to members of the President's family and lower level campaign and government officials who are perceived to be close to the President. ${ }^{135}$

This general discretionary authority thus allows the Attorney General to execute the Act more effectively by protecting the Attorney General and DOJ from conflicts of interest not codified in the Act's mandatory coverage.

A special category of discretionary coverage for Members of Congress was added in 1994. The threshold for invoking this coverage is even lower than for ordinary discretionary coverage. No conflict of interest must be present; instead, the Attorney General may apply the statutory procedures to a Member of Congress if doing so "would be in the public interest." ${ }^{136}$ Congress understood that the "broader standard enables the Attorney General to consider a larger range of factors and to exercise greater discretion" when applying the Act to Members of Congress, but concluded that this broad standard was necessary due to the increased risk of the appearance of an interbranch conflict of interest in such investigations. ${ }^{137}$

3. Conclusions on the Range of Covered Persons. The range of persons covered by the Act should reflect the Act's underlying purpose: to have investigations and prosecutions of persons close to the President or the Attorney General handled by an independent counsel. Both the number and type of official positions covered, and the length of time for which coverage is available, are based upon this purpose. Each amendment to the Act has attempted to refine the categories and terms of coverage to balance the twin risks of overinclusiveness and underinclusiveness. The coverage truest to the Act's purpose is the pure discretionary coverage now available in $\S 591$ (c) when a conflict exists, an independent counsel may be appointed. Nevertheless, to prevent the Attorney General from abusing his discretion by declining to appoint independent counsels in appropriate cases, Congress has provided specific categories of mandatory covered persons for whom an independent counsel appointment cannot be avoided. Whether the current version of these categories best balances the risks, however, remains an open question.

\section{B. Invoking the Statute}

The procedures for invoking the Act's application have a history as long and complicated as the Act itself. Before addressing the current individual elements, therefore, it is helpful to describe the historical evolution of the Act's triggering mechanisms as a whole.

135. S. REP. NO. 100-123, at 16 (1987), reprinted in 1987 U.S.C.C.A.N. 2150, 2165.

136. 28 U.S.C. $\$ 591$ (c)(2) (1994).

137. S. REP. NO. 103-101, at 36 (1993), reprinted in 1994 U.S.C.C.A.N. 748, 781. 
1. History of the Triggering Provisions. The triggering mechanisms in the 1978 Act were intended to be clear and easy to apply. The $1978 \mathrm{Act}^{138}$ created a unified procedure in $\S \S 591$ and 592. The statutory triggering process began when the Attorney General received "specific information" that a covered person may have committed a nonpetty federal criminal offense. ${ }^{139}$ The Attorney General then conducted a "preliminary investigation" to determine whether the allegations were "so unsubstantiated that no further investigation or prosecution is warranted." If If further action was warranted, however, then an independent counsel ${ }^{141}$ had to be appointed. The House Conference Report summarized this process: "When the Attorney General receives specific information that a specified individual may have violated a Federal criminal law, the Attorney General conducts a preliminary investigation of the matter, which may last for up to 90 days." 142

The 1983 amendments ${ }^{143}$ preserved the structure of the triggering procedures, but modified the language of the Act to better suit the purposes of those procedures. First, the characterization of the type of information the Attorney General must receive under $\S 591$ was changed from "specific information" that a covered person had violated a federal criminal law to "information sufficient to constitute grounds to investigate" whether a violation had occurred. ${ }^{144} \mathrm{Sec}$ ond, the type of question posed in the $\S 592$ preliminary investigation was altered, from deciding whether the allegations are "so unsubstantiated" that no further action is warranted, to determining whether there are "no reasonable grounds to believe that further investigation or prosecution is warranted." 145 Third, § 592(a) was amended to allow the Attorney General to consider during the preliminary investigation not only the specificity of the information received, but also the credibility of the information and its source. ${ }^{146}$ These changes were adopted in response to specific events, ${ }^{147}$ and from a perception that the threshold for triggering the appointment of an independent counsel had been too low. ${ }^{148}$

The period between the 1983 amendments and the next round of revisions in 1987 was a time of great controversy over the Act. Many officials in the

138. See Pub. L. No. 95-521, tit. VI, 92 Stat. 1824, $1867-73$ (1978).

139. Id., 92 Stat. at 1867 (language appearing in 1978 version of $\S 591$ (a)).

140. Id., 92 Stat. at 1868 (language appearing in 1978 version of $\S 592(\mathrm{~b})$ ).

141. The 1978 Act referred to a "special prosecutor." The term was officially changed to "independent counsel" throughout the Act in the 1983 amendments. See S. REP. No. 97-496, at 18 (1982). reprinted in 1982 U.S.C.C.A.N. 3537, 3554.

142. H.R. CONF. REP. No. 95-1756, at 77-78 (1978), reprinted in 1978 U.S.C.C.A.N. 4381, 4393-94.

143. Pub. L. No. 97-409, 96 Stat. 2039 (1983).

144. Id. § 4(a)(1), 96 Stat. at 2040 (amending $\S 591(\mathrm{a}))$.

145. Id. $\S 4$ (b), 96 Stat. at 2040-41 (language in 1983 version of various subsections of $\S 592$ ).

146. See id. (language added in 1983 to $\$ 592(\mathrm{a})$ ).

147. See infra notes $172-174,185,194-200$ and accompanying text.

148. See S. REP. No. 97-496, at 11-14 (1982), reprinted in 1982 U.S.C.C.A.N. 3537, 3547-50. The report concluded that "the present standard is too low." Id. at 11, reprinted in 1982 U.S.C.C.A.N. at 3547. 
Reagan Administration believed that the Act was unconstitutional, ${ }^{149}$ and did their best to undermine its operation. This effort created a direct backlash in Congress. Attorney General Edwin Meese "did more to ensure that the independent counsel would become a permanent part of the political landscape than any other single individual, with the notable exception of Richard Nixon.... His actions as Attorney General appeared to represent precisely the kind of behaviors that the provisions were designed to counteract." ${ }^{150}$ In response to Meese's conduct, Congress's 1987 amendments "were designed to rein in the attorney general's ability to interpret the act contrary to congressional intent." ${ }^{151}$ The 1987 Senate Report listed eight abuses and misinterpretations of the Act by the Reagan DOJ, and described how the amendments to the Act were designed to respond to each abuse. ${ }^{152}$

The 1987 amendments ${ }^{153}$ altered both the structure and substance of the statutory triggering mechanisms. First, the recusal provisions, which limit the Attorney General's role in cases in which he or she is involved, were added to $\S 591 .^{154}$ Second, the $\S 592$ preliminary investigation was restricted by additional express limitations on the Attorney General's powers at that stage. ${ }^{155}$ Third, the triggering process was divided into two independent stages: the $\S 591$ "threshold inquiry" and the $\S 592$ preliminary investigation. In the inquiry under the new version of $\S 591$, the Attorney General must examine the infor-

149. The Supreme Court ultimately held that the Act is constitutional. See Morrison v. Olson, 487 U.S. $654,659-60$ (1988). The majority concluded, inter alia, that because the Attorney General alone determines when an independent counsel appointment is triggered under the Act, and because a decision not to seek an independent counsel appointment is unreviewable, the President retains sufficient control over the independent counsel-an executive branch investigation and prosecution officer-to avoid a violation of the principle of separation of powers. See id. at 695-96. In essence, the Morrison Court held that the constitutional vesting of "the executive power" in the President does not require an unlimited power to control investigations of himself. Justice Scalia, alone in dissent, disagreed, arguing that the Act does interfere with the President's ability to control an officer in the executive branch. See id. at 705-15 (Scalia, J., dissenting). For Justice Scalia, vesting "the" executive power in the President gives him complete control of the entire executive branch, even in situations where there is a conflict of interest or the risk of abuse of power; the Constitution forces us to take those chances, with the political process as the check. See id. at 710 (Scalia, J., dissenting).

150. HARRIGER, supra note 5, at 82-83. For discussions of the controversies caused by and consequences of Attorney General Meese's statutory interpretations, see id. at 84-91.

151. Id. at 88 .

152. See S. REP. No. 100-123, at 8-14 (1987), reprinted in 1987 U.S.C.C.A.N. $2150,2157-63$ (listing abuses and misinterpretations: making unauthorized substantive "threshold inquiries" to avoid invoking the statutory preliminary investigation, evading the 90 -day deadline, improperly considering the subject's possible lack of criminal intent, too stringently interpreting the "reasonable grounds" standard for independent counsel appointment, the failure of the Attorney General to recuse himself in certain cases, wrongly opposing expansion of certain independent counsels' jurisdictions, misinterpreting the "good cause" removal standard, and interfering with independent counsels' independence by imposing certain DOJ rules on them); id. at 15-25, reprinted in 1987 U.S.C.C.A.N. at 2164-74 (describing the amendments' responses to these abuses).

153. Pub. L. No. 100-191, 101 Stat. 1293 (1987).

154. See id., 101 Stat. at 1294-95 (adding $§ 591(\mathrm{e})$ ).

155. See id., 101 Stat. at 1295-96 (modifying language of and adding language to $§ 592(a)-(c)$ ).

156. See Pub. L. No. 103-270, $\S 3(j), 108$ Stat. 732, 735 (1994) (caption referring to $\S 591$ as the "threshold inquiry"). 
mation received and determine whether to proceed to the $\S 592$ stage. $^{157}$ In making the initial $\S 591$ determination, the Attorney General may consider only the specificity and credibility of the information-the "only" was added, and the specific and credible standard moved from $\S 592(a)$ to the new $\S 591(\mathrm{~d}) .^{158}$ If the information is both specific and credible, the Attorney General notifies the Special Division and undertakes a $\$ 592$ preliminary investigation to determine whether there exist reasonable grounds to investigate further. $^{159}$

Surprisingly, the 1994 amendments ${ }^{160}$ did not make any changes to the triggering provisions. This was due in large part to Congress's conclusion that since the 1987 amendments, the Attorney General and DOJ had been in "substantial compliance" with the Act. ${ }^{161}$ The 1994 Senate Report reviewed the post-1987 practice under the Act and concluded that the triggering mechanisms were functioning effectively and were no longer being abused. ${ }^{162}$

2. The Threshold Inquiry. The $\$ 591$ threshold inquiry was not originally a separate stage of the statutory triggering procedures. The threshold inquiry and the $\S 592$ preliminary investigation were bifurcated in the 1987 amendments to the Act. ${ }^{163}$ Although these two stages are similar, they now serve different purposes. Unlike the preliminary investigation (discussed below), the threshold inquiry is a highly limited review, but it does permit a matter to be closed without any report to the Special Division.

a. The information received. The $\S 591$ threshold inquiry begins when the Attorney General "receives information sufficient to constitute grounds to investigate whether" a covered person may have committed a federal criminal violation. ${ }^{164}$ The meaning of this phrase might pose interpretive difficulties. In reality, however, the history of this phrase makes clear that its meaning is in fact very simple.

The 1978 version of $\S 591$ (which applied to the original unified triggering procedure) provided that the statutory procedures would be triggered when the Attorney General received "specific information" about a federal criminal violation by a covered person. "The term 'specific information' [was] used so

157. See Pub. L. No. 100-191, 101 Stat. 1293, 1293 (1987) (changing the language of $\S 591$ (a) to make clear that $\S 591$ and $\S 592$ are different inquiries). Instead of $\S \S 591-592$ determining whether an "investigation" under "this chapter" is needed, as was the case under the previous $\S 591$ (a), the 1987 amendments clarified $\S 591(\mathrm{a})$ to read that the $\$ 591(\mathrm{a})$-(d) inquiry determines whether a "preliminary investigation ... under section 592" should proceed.

158. See id., 101 Stat. at 1294 (moving specific and credible provision of the previous $\S 592$ (a) to a new $\$ 591(d)$, unchanged in substance except for the addition of "only" before the dash).

159. See id., 101 Stat. at $1295-97$ (preserving reasonable grounds standard in $\S 592$, despite moving specific and credible provision into $\$ 591(\mathrm{~d}))$.

160. Pub. L. No. 103-270, 108 Stat. 732 (1994).

161. S. REP. No. 103-101, at 14 (1993), reprinted in 1994 U.S.C.C.A.N. 748, 758.

162. See id. at 12-14, reprinted in 1994 U.S.C.C.A.N. at 756-59.

163. See supra notes $157-159$ and accompanying text.

164. 28 U.S.C. $\$ 591$ (a) (1994). 
that the provisions of this chapter [would] not apply to a generalized allegation of wrongdoing which contains no specific factual support." ${ }^{165}$ As long as the information received was specific, not general, the Attorney General was required to determine in a preliminary investigation (using the unified $\S 591$ and 592 procedure) whether the allegations were nevertheless so unsubstantiated that no further action was warranted.

Congress concluded in its first review of the Act that this original standard of review was too low, and in 1983 amended $\S 592$ to authorize the Attorney General to consider in the initial investigation (under $\$ \S 591$ and 592 together) not only the specificity of the allegation, but also the credibility of its source. ${ }^{166}$ This change, of course, meant that the language referring to the receipt of "specific" information would have to be amended as well, because the information received must not only be specific, but also credible. Congress thus replaced "specific information" with "information sufficient to constitute grounds to investigate."

Congress never expressly stated that the new language was merely a proxy for the new specific and credible standard, although such a conclusion can be inferred from the legislative history. ${ }^{167}$ Similarly, when the $\$ 591$ threshold inquiry and $\S 592$ preliminary investigation were divided in 1987 , Congress never directly addressed how the division might affect the "information sufficient to constitute grounds to investigate" standard in $\S 591$. By moving the specific and credible provision into $\S 591$ and by adding the word "only," however, ${ }^{168}$ Congress made clear that after 1987, "information sufficient to constitute grounds to investigate" means merely that-and means only that-the Attorney General finds the allegations to be specific and credible. ${ }^{169}$ Thus, under the current Act, the Attorney General's determination that the information received is specific and credible is necessary and sufficient to meet the $\S 591$ threshold inquiry and to proceed to the $\S 592$ preliminary investigation.

$b$. The threshold inquiry standard of review. If the information received by the Attorney General is specific and credible, then a $\S 592$ preliminary investigation must proceed, including a report to the Special Division at the

165. S. REP. NO. 95-170, at 52 (1977), reprinted in 1978 U.S.C.C.A.N. 4216, 4268. The report illustrates this concept by noting that the receipt of a letter alleging that a Cabinet member is a "crook," but providing no further information or support for that allegation, would constitute nonspecific information. See id.

166. See supra note 146 and accompanying text.

167. See S. REP. NO. 97-496, at 11-13 (1982), reprinted in 1982 U.S.C.C.A.N. 3537, 3547-49 (discussing the addition of credibility, and using the new "information sufficient to constitute grounds" language in a manner that suggests that it was intended to encompass the old specificity requirement and the new elements added in 1983).

168. See supra note 158 and accompanying text; infra notes $175-177$ and accompanying text.

169. See S. REP. No. 100-123, at 15 (1987), reprinted in 1987 U.S.C.C.A.N. 2150, 2164 (discussing the newly separated $\$ 591$ threshold inquiry in light of "Congress' intent that the decision to initiate a preliminary investigation rest on these two factors alone"). 
beginning and at the end of that process. ${ }^{170}$ If the information is not specific and credible, however, the matter may be closed at the $\S 591$ stage, without any report to the Special Division or the public. ${ }^{171}$ The interpretation of the "specific and credible" standard is thus of great importance.

In adopting the "specific and credible" standard of review in 1983, Congress reasoned that the previous standard (under the then-unified $\$ \S 591$ and 592 procedure) for determining when a preliminary investigation was needed was set too low:

[T] he present standard is too low by not allowing the Attorney General to consider the credibility of the person making the allegation in determining whether a preliminary investigation is required. Any allegation, even by a source known by the Department to be unreliable, can trigger a preliminary investigation. ... [T]his standard creates unfairness by imposing a stricter application of criminal law on public officials than that imposed on private citizens. It also invites abuse of the [independent counsel] process by persons who want to harm the reputations of public officials. Finally, this standard wastes valuable Department of Justice resources by requiring high priority investigations in situations where no one else would be investigated. ${ }^{172}$

The "specific" requirement preserves the principle that the Act is not triggered by general or unsupported allegations, ${ }^{173}$ and the new 1983 "credible" requirement allows the Attorney General to "follow the usual practices of [DOJ] in determining the reliability of a source," such as the person's previous reliability. $^{174}$

This standard of review was further clarified in the 1987 amendments. The specific and credible standard was moved from $\S 592(a)$ into a new $\S 591(d)$, and the language was amended so that the Attorney General "shall consider only-(A) the specificity ... and (B) credibility" of the information and its source when deciding under $\S 591$ whether to proceed to a $\S 592$ preliminary investigation. ${ }^{175}$ Congress intended this change to clarify the very limited scope of the newly separated $\S 591$ threshold inquiry: ${ }^{176}$ "This limitation applies, of course, only to that early stage of the case in which the Attorney General is deciding whether to initiate a preliminary investigation of the matter; it does not apply to the preliminary investigation itself, in which the Attorney General may consider additional factors." 177 Therefore, a matter can be disposed of un-

170. See 28 U.S.C. $\$ 592(a)(1)$, (b)-(c) (1994) (requiring Attorney General to report to Special Division both upon initiating a $\$ 592$ preliminary investigation and at its conclusion whether he or she seeks or declines to seek appointment of an independent counsel).

171. See id. \$ 591(d) (stating that Attorney General "shall close the matter" if information is not specific and credible, without any reporting requirement; and stating that the Attorney General "shall ... commence" a $\$ 592$ preliminary investigation if information is specific and credible, or if no determination can be made within allotted time).

172. S. REP. NO. 97-496, at 11-12 (1982), reprinted in 1982 U.S.C.C.A.N. 3537, 3547-48.

173. See id. at 12, reprinted in 1982 U.S.C.C.A.N. at 3548

174. Id.

175. See supra note 158 and accompanying text.

176. See S. REP. No. 100-123, at 15 (1987), reprinted in 1987 U.S.C.C.A.N. 2150,2164 (stating that amendment "adds the word 'only' to the current standard for deciding whether to conduct a preliminary investigation, to emphasize Congress' intent that the decision to initiate a preliminary investigation rest on these two factors alone").

177. H.R. CONF. REP. NO. 100-452, at 21 (1987), reprinted in 1987 U.S.C.C.A.N. 2185, 2187. 
der $\S 591$ as not specific or credible, but a disposition on any other basis requires a $\$ 592$ preliminary investigation and the accompanying reporting requirements.

c. Length of time. When the separate $\S 591$ threshold inquiry was created in 1987, the Act imposed a limitation of fifteen days on this stage of the triggering procedures. ${ }^{178}$ At the request of Attorney General Janet Reno, Congress extended this period to thirty days in the 1994 amendments, "to give the Attorney General additional time to determine whether a preliminary investigation is warranted under the law." very short time limitation on the threshold inquiry, severely limiting the Attorney General's ability to dismiss matters without a preliminary investigation. ${ }^{180}$

3. The Preliminary Investigation. The $\S 592$ preliminary investigation is perhaps the most controversial segment of the Act's triggering mechanisms. The preliminary investigation requirements attempt to strike a balance between, on the one hand, allowing the Attorney General sufficient authority to dismiss matters that are not worthy of a federal criminal investigation, and, on the other hand, constraining the Attorney General's role merely to screening cases for their investigative worthiness and not their substantive merits. The history of the preliminary investigation's practice and statutory amendment indicate that the right balance remains elusive.

a. The preliminary investigation standard of review. The language used to describe the method and standard of review applied by the Attorney General at the $\S 592$ preliminary investigation stage has changed, but its underlying purpose has remained the same: "A 'preliminary investigation' is the type of initial investigation which is conducted to determine whether a case warrants further investigation ... to weed out frivolous cases.... [If] a more complete investigation is required, such as the subpoenaing of documents, the preliminary investigation stage has been completed," and the investigation is turned over to an independent counsel appointed by the Special Division. ${ }^{181}$

178. See Pub. L. No. 100-191, 101 Stat. 1293, 1294 (1987) (1987 version of $\S$ 591(d)).

179. S. REP. NO. 103-101, at 26 (1993), reprinted in 1994 U.S.C.C.A.N. 748, 771.

180. One of the chief congressional criticisms of Attorney General Meese's interpretation of the Act was his procedure of undertaking what he called "threshold inquiries." These often involved "elaborate factual and legal analyses," yet Meese asserted that they did not trigger a statutory preliminary investigation and the accompanying reporting requirement. See S. REP. NO. 100-123, at 9 (1987), reprinted in 1987 U.S.C.C.A.N. 2150,2158 . It was to abolish this practice that the 1987 amendments established the statutory $\S 591$ threshold inquiry, at which only specificity and credibility may be considered; to consider any other factor, the Attorney General must begin a statutory $\$ 592$ preliminary investigation. See id. at 15, reprinted in 1987 U.S.C.C.A.N. at 2164.

181. S. REP. NO. 95-170, at 53-54 (1977), reprinted in 1978 U.S.C.C.A.N. 4216, 4269-70; see also S. REP. NO. 97-496, at 14 (1982), reprinted in 1982 U.S.C.C.A.N. 3537, 3550 ("As soon as it becomes apparent that a matter justifies further investigation, the purpose of a preliminary investigation has been completed, and the matter should be referred immediately to the court for the appointment of a special prosecutor."). 
The preliminary investigation serves only a screening function: to eliminate groundless cases, but not to close matters that deserve a further look. ${ }^{182}$

The 1978 version of the Act described the preliminary investigation standard as a determination of whether the allegations were so unsubstantiated that no more investigation or prosecution was warranted. ${ }^{183}$ The preliminary investigation allowed the Attorney General "to weed out the totally unsubstantiated allegations," but "as soon as there is any indication whatsoever that the allegations... have any potential chance of substantiation," the 1978 version required that an independent counsel be appointed. ${ }^{184}$ (This language and intent is very similar to that currently defining a $\$ 591$ threshold inquiry.)

The 1983 amendments modified the Attorney General's determination from whether the allegations are (1) so unsubstantiated (2) that no further investigation or prosecution is warranted, to whether there are (1) reasonable grounds (2) to believe that further investigation or prosecution is warranted. ${ }^{185}$ This change achieved two purposes. First, it shifted the focus of the preliminary investigation away from exclusively the information contained in the allegations and whether it could be substantiated, to any "reasonable grounds" that might or might not influence whether further investigation is warranted. Second, by acknowledging that the question is whether the Attorney General "believes" there are grounds for further investigation at this early stage, the change recognized the role of the Attorney General's subjective judgment in the preliminary investigation process.

The 1987 amendments to the Act reinforced these changes. First, the bifurcation of the $\S 591$ threshold inquiry and the $\S 592$ preliminary investigation and the accompanying alterations in the text, ${ }^{186}$ emphasized that the threshold inquiry was an extremely limited review of the allegations alone, while the preliminary investigation could include other factors bearing on the merit of further investigation. Second, the amendments included numerous express limitations on the Attorney General's authority during a preliminary investigation. These limits, on their face and by implication, acknowledged that the preliminary investigation can range beyond the mere allegations themselves. Third, a significant change was made to the language of $\S 592$-limiting the determination to whether "further investigation" was warranted, and deleting the refer-

182. Attorney General Meese was accused by Congress of thwarting this principle by not merely screening cases for whether an independent counsel appointment is appropriate, but by dismissing cases on the merits during a preliminary or even pre-preliminary investigation. See supra note 180; see also S. REP. No. 100-123, at 6-8, 15 (1987), reprinted in 1987 U.S.C.C.A.N. 2150, 2155-57, 2164.

183. See supra note 140 and accompanying text.

184. S. REP. NO. 95-170, at 54 (1977), reprinted in 1978 U.S.C.C.A.N. 4216, 4270.

185. Congress adopted these two changes in response to specific events and to problems with the previous language. See S. REP. No. 97-496, at 12 (1982), reprinted in 1982 U.S.C.C.A.N. 3537, 3548 (discussing how the addition of credibility to specificity analysis would influence reasonable grounds determination); id. at 14-15, reprinted in 1982 U.S.C.C.A.N. at 3550-51 (discussing role of established DOJ policies in reasonable grounds determination).

186. See supra notes 157-159 and accompanying text. 
ences to "or prosecution" 187 - that clarified Congress's intent that "a decision to proceed or not to proceed under the Act must rest on a judgment about the need for further 'investigation' rather than on the ultimate prospects for conviction." 188

The sum of these changes to the preliminary investigation standardwhether there are reasonable grounds to believe that further investigation is warranted-is a relatively clear principle. Once the Attorney General has found the allegations to be specific and credible under $\S 591$, a $\S 592$ preliminary investigation begins. During the preliminary investigation, the Attorney General may conclude that the allegations alone are sufficient to warrant further investigation, may thus immediately find $\S 592$ reasonable grounds to do such further investigation, and may apply to the Special Division for the appointment of an independent counsel. The Attorney General need not do this, however. Instead, at the $\$ 592$ preliminary investigation stage, the Attorney General also may consider any other factors bearing on the warrant of further investigation (within the statutory constraints on the Attorney General's authority at this stage). If these other factors reinforce the need for further investigation, or muddy the matter and the time restriction runs out, then the Attorney General is obligated to find that reasonable grounds exist and to request the appointment of an independent counsel. ${ }^{189}$ If, on the other hand, these other factors counsel against any further investigation, the Attorney General need merely report the factual basis for that conclusion to the Special Division, and the matter will be closed without the appointment of an independent counsel. ${ }^{190}$ Attempts to argue that the $\S 592$ reasonable grounds standard requires some higher level of proof have been rejected. ${ }^{191}$

b. Limitations on the preliminary investigation review. The screening purpose of the preliminary investigation can be successful only if the scope of the Attorney General's investigation at this stage is restricted. A broadranging substantive investigation would undermine the Act by undertaking tasks that were intended to be performed by the independent counsel. On the other hand, too many restrictions on the Attorney General's authority would

187. See Pub. L. No. 100-191, 101 Stat. 1293, 1295-97 (1987) (making this change throughout $\$ 592$ ).

188. S. REP. NO. 100-123, at 18-19 (1987), reprinted in 1987 U.S.C.C.A.N. 2150, 2167-68. Congress was directly responding to and rejecting the "reasonable prospect of conviction" interpretation of the $\S 592$ standard asserted by Attorney General Meese in several potential independent counsel cases. See id. at 11, reprinted in 1987 U.S.C.C.A.N. at 2160.

189. See 28 U.S.C. \& 592(c)(1) (1994).

190. See id. $\$ 592$ (b).

191. Attorney General Meese asserted that the "reasonable grounds" standard should be interpreted to require that, before requesting the appointment of an independent counsel, the Attorney General must find a level of information closer to probable cause or even a preponderance of the evidence. See In re Meese, 907 F.2d 1192 (D.C. Cir. 1990). The Special Division has consistently rejected this argument: Because the preliminary investigation serves a screening function, and because the Attorney General's appointment determination is not reviewable, the reasonable grounds standard must be low, allowing the Attorney General to request an independent counsel appointment as he or she sees fit. See In re Herman, 144 F.3d 829 (D.C. Cir. 1998) (rejecting argument that reasonable gr ounds standard should be given a more stringent interpretation). 
make the preliminary investigation too similar to the threshold inquiry, and could lead to the unwarranted appointments of independent counsels. As with the preliminary investigation standard of review, Congress has imposed several restrictions on the Attorney General's authority in an effort to strike the appropriate balance between these two principles. For example, the 1978 Act dictated that the Attorney General "shall have no authority to convene grand juries, plea bargain, grant immunity, or issue subpoenas." 192 These limits proved to be insufficient, however, particularly in light of the misuse of the Act by the Reagan Administration. ${ }^{193}$ The subsequent amendments to the Act each sought to refine the preliminary investigation balance.

i. Department of Justice policies. The first significant change to the restrictions was intended to correct the Act's overinclusiveness-where an independent counsel would be appointed even if the criminal violation alleged was an offense for which federal investigations or prosecutions were rare or even nonexistent. This problem first arose in the cases of Carter advisors Hamilton Jordan and Timothy Kraft. Information was received that each man had been seen using cocaine at the Studio 54 disco in New York City. ${ }^{194}$ Despite the fact that such allegations would be "generally ignored by United States attorneys when made against ordinary citizens," independent counsels were appointed to investigate both men; no charges were ever filed in either case. $^{195}$

Congress reacted to the Jordan and Kraft cases ${ }^{196}$ by allowing the Attorney General to consider "written or other established policies of the Department of Justice" relating to the enforcement of criminal laws, ${ }^{197}$ thereby reducing the previous "hair trigger" standard. ${ }^{198}$ Congress acknowledged that executive branch prosecutorial discretion-"in those clear cases in which there is an established, demonstrable policy not to prosecute" "-has some role to play even in the preliminary investigation stage. If the Attorney General bases his decision not to seek the appointment of an independent counsel upon such a nonprosecution policy,

[i]n his report to the [Special Division], the Attorney General must substantiate this practice with case law, opinions of the U.S. Attorney for the district in which the violation was alleged to have occurred, written prosecutorial guidelines, or other evidence that no prosecution would be brought.... Any case in which there is no clear

192. 28 U.S.C. $\$ 592(a)(2)(A)(1994)$.

193. See generally supra notes $150-152,180,182,188$ and accompanying text.

194. See HARRIGER, supra note 5, at 75 .

195. Id.

196. See S. REP. NO. 97-496, at 14-15 (1982), reprinted in 1982 U.S.C.C.A.N. 3537, 3550-51 (discussing the two cases as impetus for including DOJ policies provision).

197. 28 U.S.C. $\S 592$ (c)(1) (1994).

198. HARRIGER, supra note 5, at 75 (quoting former Attorney General Benjamin Civiletti's description of the standard).

199. S. REP. NO. 97-496, at 15 (1982), reprinted in 1982 U.S.C.C.A.N. 3537, 3551. The relevant policies to be considered are those particular to the crime alleged. A general DOJ policy not to prosecute weak cases may not be relied upon. 
policy against prosecution or any arguably exceptional circumstances are present should be sent to a special prosecutor. ${ }^{200}$

The DOJ policies provision was amended in 1987, however, when Congress determined that the Reagan Administration had been abusing the provision by misinterpreting its scope: By considering the concept of DOJ policies on the "enforcement of criminal laws" in a certain way, Attorney General Meese transformed "reasonable grounds to believe further investigation or prosecution is warranted" into whether a "reasonable prospect of conviction" existed. ${ }^{201}$ This interpretation undermined the preliminary investigation's screening role by allowing the Attorney General, rather than the independent counsel, to make determinations on the chances for success in a particular case. Therefore, Congress corrected the language of the restriction to read DOJ policies "with respect to the conduct of criminal investigations" similar interpretation in the future.

The DOJ policies provision allows the Attorney General to dismiss a matter at the preliminary investigation stage in cases where the alleged violation is one which is ordinarily not investigated or prosecuted. In addition, because the DOJ policies provision remains part of the $\S 592$ preliminary investigation and not the $\S 591$ threshold inquiry, the Attorney General must report to the Special Division each time an independent counsel appointment is rejected because the existence of a nonprosecution or other DOJ policy provides the basis for the "no reasonable grounds" finding. ${ }^{203}$ This reporting requirement creates a check against future abuse of the DOJ policies provision by the Attorney General.

ii. Criminal state of mind. In 1987, Congress further limited the Attorney General's authority by entirely prohibiting consideration during the $\S 591$ threshold inquiry ${ }^{204}$ of whether the accused person "lacked the state of mind required for the violation of criminal law." 205 In addition, Congress amended the Act to permit the Attorney General to base a $\$ 592$ preliminary investigation finding of "no reasonable grounds" to support the appointment of an independent counsel upon a determination of a lack of mens rea only if "there is clear and convincing evidence." 206

Congress intended the bar against the use of mens rea evidence in the preliminary investigation to be very high, because Congress believed that Attorney General Meese had relied too frequently on such grounds when declining to seek independent counsel appointments. ${ }^{207}$ Congress reasoned that "[s]tates of

200. Id.; see also 28 U.S.C. \& 592(b) (1994).

201. S. REP. NO. 100-123, at 19 (1987), reprinted in 1987 U.S.C.C.A.N. $2150,2168$.

202. 28 U.S.C. $\$ 592$ (c)(1) (1994) (emphasis added).

203. Id. $\S 592(\mathrm{~b})$.

204. See id. $\$ 592(\mathrm{a})(2)(\mathrm{B})(\mathrm{i})$.

205. Id. $\S 592(\mathrm{a})(2)(\mathrm{B})$ (originally adopted as part of $\S 592(\mathrm{a})(1))$.

206. Id. \&592(a)(2)(B)(ii).

207. See S. REP. NO. 100-123, at 18 (1987), reprinted in 1987 U.S.C.C.A.N. 2150, 2167. 
mind are inherently difficult to prove," require a fuller investigation than the Attorney General is permitted during a preliminary investigation, and demand "subjective judgments" outside the Attorney General's limited role in the statutory process. ${ }^{208}$ Congress thus concluded that

[i]t is theoretically possible that the Attorney General would have a case in which the evidence disproving criminal intent is so compelling that it justifies closing the entire matter.... However, in the more common situation where there is conflicting or inconclusive evidence on the subject's state of mind, the provision prohibits the Attorney General from closing the case solely because he or she has evaluated the evidence and found the evidence against intent more persuasive or the evidence establishing intent insufficiently strong. ${ }^{209}$

If the Attorney General does rely on state of mind evidence to justify closing a $\S 592$ preliminary investigation, the Special Division reporting requirement ensures outside oversight of that justification.

The 1994 reauthorization debates included a Senate proposal to lessen this bar on state of mind evidence during a preliminary investigation. ${ }^{210}$ The full Congress rejected the proposal, however, and retained the strict prohibition; Congress concluded that because state of mind considerations had been abused previously, it was best to preserve the strict prohibition to prevent future problems. $^{211}$

iii. Other limitations. The 1987 amendments ${ }^{212}$ modified $\$ 592$ in other ways to restrict and monitor the Attorney General during the preliminary investigation. $^{213}$ The language of $\S 592(\mathrm{a})$ was tightened to make clear that the ninety-day time limit is mandatory, except if the Attorney General requests and is granted a sixty-day extension by the Special Division. A modification in $\S 592$ (c) also clarified that the receipt of additional information about a matter previously closed after a preliminary investigation without an independent counsel appointment compels the beginning of a new preliminary investigation to address the new information. In addition, $\S 592(\mathrm{a})$ was amended to require the Attorney General to report to the Special Division when each preliminary investigation is commenced. Finally, $\S 592(\mathrm{~g})$ was added to address preliminary investigations begun by the Attorney General at the request of Congress. ${ }^{214}$

c. Length of time. Unlike most elements of the $\S 592$ preliminary investigation, the ninety-day time limitation has remained unchanged. ${ }^{215}$ The only modification to the time restriction was added by the 1983 amendments:

\footnotetext{
208. Id.

209. Id.

210. See S. REP. NO. 103-101, at 34 (1993), reprinted in 1994 U.S.C.C.A.N. 748, 779.

211. See H.R. CONF. REP. NO. 103-511, at 11 (1994), reprinted in 1994 U.S.C.C.A.N. 792, 794.

212. This paragraph summarizes the changes made to $\S 592$ by Pub. L. No. 100-191, 101 Stat. 1293, 1295-97 (1987).

213. These amendments were primarily a reaction to the abuses of the Act by Attorney General Meese. See supra notes $150-152,193$ and accompanying text.

214. See supra notes 49-54 and accompanying text (describing congressional request procedures).

215. See 28 U.S.C. $\$ 592(a)(1)$ (1994).
} 
The Attorney General may receive up to a sixty-day extension from the Special Division upon a showing of good cause. ${ }^{216}$ Congress made clear, however, that this restriction should be the exception, not the rule.

In making his application, the Attorney General should specifically state the grounds upon which he requests an extension. [Congress] intends that the court will grant these extensions only in cases where the Attorney General has specifically shown that a limited extension may enable him to resolve the preliminary investigation without a special prosecutor. ${ }^{217}$

Most preliminary investigations easily should conclude within ninety days; given the preliminary investigation's limited screening function, this result is entirely appropriate.

4. Recusal of the Attorney General. One of the most important amendments to the triggering procedures is the recusal provision of $\S 591(\mathrm{e})$. Included in the 1987 amendments, ${ }^{218}$ this rule requires the Attorney General to determine whether his or her recusal is required "[b]efore personally making any other determination under [the Act]." "219 The result of this determination must be reported to the Special Division, including the Attorney General's reasons. $^{220}$

Congress inserted the recusal provision because it believed that Attorney General Meese had abused the Act by improperly failing to recuse himself from the (then-unified $\S \S 591$ and 592) preliminary investigations of several cases with the potential for independent counsel appointments. ${ }^{221}$ To correct this problem in the future, Congress made its intent very clear. The recusal provision "requires the Attorney General to consider recusal in every independent counsel case. ... The recusal decision must be made prior to the Attorney General's making any other determination required by the Act," such as whether the threshold inquiry dictates the need for a preliminary investigation, or whether the preliminary investigation demonstrates the need for an independent counsel appointment. ${ }^{222}$ Recusal is required in any case where the Attorney General "participated in the underlying facts or had the type of relationship with a person in the case which creates an appearance of or an actual conflict of interest. It deliberately rejects the suggestion that the Attorney General employ any type of presumption against recusal."223 Finally, the re-

216. See id. § 592(a)(3).

217. S. REP. NO. 97-496, at 13 (1982), reprinted in 1982 U.S.C.C.A.N. 3537, 3549.

218. The text of $\S 591(\mathrm{e})$ was reorganized and slightly rewritten in the 1994 amendments, but with no change in the substantive meaning. Compare Pub. L. No. 100-191, 101 Stat. 1293, 1294-95 (1987) (original version), with Pub. L. No. 103-270, § 3(k), 108 Stat. 732, 735-36 (1994) (modified version).

219. 28 U.S.C. $\S 591(\mathrm{e})(2)(1994)$.

220. See id.

221. See S. REP. No. 100-123, at 11 (1987), reprinted in 1987 U.S.C.C.A.N. 2150, 2160 ("There are several independent counsel cases in which the Attorney General's failure to recuse himself is extremely troubling."); see also id. at 11-12, reprinted in 1987 U.S.C.C.A.N. at 2160-61 (discussing the troublesome cases).

222. Id. at 16-17, reprinted in 1987 U.S.C.C.A.N. at 2165-66.

223. Id. at 16, reprinted in 1987 U.S.C.C.A.N. at 2165. 
quirement of a report to the Special Division on the Attorney General's recusal determination "applies whether the Attorney General ultimately decides in favor of or against recusal. Its purpose is to enable other persons to better understand the standards and reasoning used by the Attorneys General in reaching a recusal decision." 224

The recusal provision of $\S 591(\mathrm{e})$ is intended to be a significant check on the Attorney General's ability to contravene the Act by remaining involved in cases in which he or she is interested. Although the Act provides no sanction or remedy for an improper recusal determination, the reporting requirement is presumably intended as a political and public relations check on the Attorney General's discretion.

\section{Conclusion: The Triggering Mechanisms}

The current version of the Act's triggering mechanisms is the result of the controversial history of the Act itself. Congress has struggled to achieve a stable balance between opposing forces, hoping neither to initiate unnecessary independent counsel investigations nor to allow the statutory scheme to be undermined by the executive branch. The number and nature of the Act's covered persons has expanded and contracted as Congress sought to find the appropriate range of individuals for whom only independent counsels, and not Attorneys General and DOJ, should undertake investigations. The threshold inquiry and preliminary investigation were divided, creating a structure designed to check the Attorney General's discretion in the triggering procedures: A matter may be closed by the Attorney General in silence only on the ground that the allegations are not specific and credible; closing a matter without appointing an independent counsel on any other ground requires a preliminary investigation and reports to the Special Division. Furthermore, Congress has erected a series of limitations on the $\S 592$ preliminary investigation, from the early prohibitions including barring the use of grand juries or plea bargaining to recent additions such as requiring a clearly established nonprosecution policy or clear and convincing evidence of the lack of mens rea. Finally, the Act requires the Attorney General to consider and file a report on recusal in every case. Each of these provisions and procedures is dedicated to achieving the Act's central function: triggering an independent counsel investigation only when one is needed. Despite the attempts at refinement over twenty years, accomplishing this central purpose of the Act remains elusive.

224. Id at 17, reprinted in 1987 U.S.C.C.A.N. at 2166 (emphasis added). But cf. 28 U.S.C. \$591(e)(2) (1994) ("The Attorney General shall set forth this determination in writing, identify the facts considered by the Attorney General, and set forth the reasons for the recusal." (emphasis added)). 
IV

\section{RELATIONSHIPS CREATED AND ALTERED BY THE OPERATION OF THE ACT}

The independent counsel statute has created and altered many complex relationships within and among the executive, legislative, and judicial branches of the federal government. This part of the article examines the relationships between the independent counsel and other relevant actors in the political system: the public, the "Special Division" court that oversees independent counsel investigations, the Department of Justice and the Attorney General, and Congress.

\section{A. The Relationship Between the Act and Private Citizens}

Private citizens repeatedly have sought to use the courts to compel the Attorney General to undertake a preliminary investigation under the Act or to force the Attorney General to appoint an independent counsel after having undertaken a preliminary investigation. In rejecting these claims, the courts have expounded upon the function of the independent counsel and that office's role in the criminal justice system.

1. Private Citizens Cannot Compel the Attorney General to Conduct a Preliminary Investigation. A trilogy of federal court of appeals cases has held that private citizens may not use the federal courts to compel the Attorney General to undertake a preliminary investigation. First, in Nathan v. Smith, ${ }^{225}$ the plaintiffs, who were survivors of an attack by the Ku Klux Klan and the American Nazi Party, ${ }^{226}$ alleged that, after having received information regarding these events, the Attorney General wrongly failed to appoint an independent counsel. ${ }^{227}$ The D.C. Circuit reversed the district court's order that the Attorney General conduct a preliminary investigation under $\S 592$, but did so in a fourteen-word per curiam opinion. Individual judges offered little guidance in much longer concurring opinions. Judge Davis would have reached the merits of the case and then held that the plaintiffs had presented the Attorney General with nothing other than "conclusory generalizations" and "suspicions"- not enough to require the Attorney General to undertake a preliminary investigation. ${ }^{228}$ Judge Bork would have held that the court lacked jurisdiction to hear the case and found that the Act created no private right of

225. 737 F.2d 1069 (D.C. Cir. 1984) (per curiam).

226. See id. at 1070-71 (Davis, J., concurring).

227. See id. at 1071 (Davis, J., concurring). The plaintiffs claimed that they had supplied the Attorney General with information that individuals covered under the Act had violated federal criminal law and that he had failed to conduct a preliminary investigation. See id. The Attorney General maintained that he did not seek appointment because he believed that the allegations did not concern persons covered under the Act. See id. The Attorney General instead referred the matter to DOJ's Civil Rights Division. See id.

228. Id. at 1076-77 (Davis, J., concurring). 
action to compel the Attorney General to undertake a preliminary investigation. ${ }^{229}$

Within days of deciding Nathan, however, the D.C. Circuit sitting en banc reached the same conclusion but supplied a rationale for its holding. In Banzhaf v. Smith, ${ }^{230}$ the plaintiffs had presented information to the Attorney General indicating that the Reagan Administration might have committed crimes during the 1980 presidential campaign. ${ }^{231}$ When, ninety days after receiving the information, the Attorney General had not decided whether to seek the appointment of an independent counsel, the plaintiffs sued to compel him to do so. ${ }^{232}$ In reversing the decision of the district court ordering the Attorney General to conduct a preliminary investigation, the court noted that Congress explicitly had intended to preclude private citizens from using the courts to challenge the Attorney General's decision not to investigate or seek the appointment of an independent counsel. ${ }^{233}$ The court stated that such private actions were unnecessary because congressional oversight provides an effective enforcement mechanism. ${ }^{234}$

Finally, the Ninth Circuit reached the same result in Dellums v. Smith. ${ }^{235}$ In Dellums, the plaintiffs sought to force Attorney General William French Smith to conduct a preliminary investigation. ${ }^{236}$ The court below found that the Act

\section{See id. at 1077 (Bork, J., concurring).}

230. 737 F.2d 1167 (D.C. Cir. 1984) (en banc) (per curiam).

231. See id. at 1168; see also John F. Banzhaf III, Upset at Reno's Decision? Take Her to Court, FULTON COUNTY DAILY REP., Dec. 12, 1997, at 7. Banzhaf had petitioned Attorney General William French Smith to investigate "Debategate"-the unauthorized removal of materials from the Carter White House to Reagan campaign headquarters during the 1980 presidential campaign. When Smith refused to act on the information, Banzhaf brought the case to court. Banzhaf argues that the holding in the Court of Appeals was limited to "private parties" or "members of the public" who sought review of the Attorney General's decision not to appoint an independent counsel: Since Members of Congress are explicitly authorized to petition the Attorney General to appoint an independent counsel under $\$ 592(\mathrm{~g})$, Republicans on the Judiciary Committee might have been able to obtain judicial review of Attorney General Janet Reno's decision in late 1997 not to appoint an independent counsel to investigate Democratic fund-raising irregularities. See Banzhaf, supra. Banzhaf maintains that

[a] statute designed to prevent abuses that occur when the Justice Department refuses to in-

vestigate criminal wrongdoing by high administration officials and that sets precise standards and timetables for the appointment of an independent counsel if very low standards of evidence are met is reduced to a nullity if an attorney general's refusal to comply is immune Id.

from any review.

232. See Banzhaf, 737 F.2d at 1168; see also supra Part III.B.3.c (discussing the 90-day time limitation of the preliminary investigation).

233. See Banzhaf, 737 F.2d at 1168 . The court noted that two bills that did not pass during the debate of the Act would have allowed for review by private parties. See id. at 1170 (citing H.R. 11476, 94th Cong. (1976), and S. 495, 94th Cong. (1976)).

234. See id. at 1169 .

235. 797 F.2d 817 (9th Cir. 1986).

236. See id. at 818 . The plaintiffs were Ronald Dellums (a Member of Congress) and two others who, in January 1983, had sent a detailed letter about United States involvement in Nicaragua to Attorney General Smith. See id. at 819. This letter asked the Attorney General to conduct a preliminary investigation under the Act to determine whether certain executive officials, including President Reagan, Secretary of Defense Alexander Haig, Secretary of State George Schultz, and others in the Administration had committed criminal offenses in connection with the Nicaraguan campaign. See id. 
imposed mandatory duties on the Attorney General and issued injunctions ordering the Attorney General to comply with the provisions of the Act. ${ }^{237}$ However, while the Act does impose mandatory duties on the Attorney General, the Ninth Circuit held that private citizens could not challenge in federal court the failure of the Attorney General to discharge those duties. ${ }^{238}$ The Ninth Circuit held that the legislative history of the Act, when examined in the context of the entire statutory scheme, manifests an intent to preclude review by private citizens. ${ }^{239}$ The court dismissed the lower courts' argument that such a holding would render the Act a nullity, and it noted that, at the time of the Act's enactment, Congress envisioned that oversight by members of the congressional judiciary committees would ensure that the Attorney General obeys the law. ${ }^{240}$

Although the undisputed purpose of the Act is to foster public trust and confidence in government-a trust that is called into question when high-level governmental officials investigate themselves--the courts in Banzhaf and Dellums found that Congress, not the public, is the proper check against the Attorney General's noncompliance with the Act. ${ }^{241}$ During the 1987 reenactment of the Act, Congress resolved the issue once and for all by codifying the holdings of Dellums and Banzhaf by adding a provision that expressly limits the authority of the federal courts to overrule a decision by the Attorney General to refuse to conduct a preliminary investigation in a particular case. ${ }^{242}$

237. See id. at 818 . The district court in Dellums had held that the Act would be rendered meaningless and its purpose defeated if a court could not order the Attorney General to conduct an investigation upon the request of a credible person supplying specific information of criminal wrongdoing. See Dellums v. Smith, 573 F. Supp. 1489, 1493 (N.D. Cal. 1983), rev'd, 797 F.2d 817 (9th Cir. 1986). In so holding, the court believed the purpose of the Act was to deny the Attorney General the power to refuse to make at least a preliminary investigation upon the receipt of reasonably specific information from credible sources alleging the violation of federal criminal law by members of the executive branch. See id.

238. See Dellums, 797 F.2d at 819 . Furthermore, the statute made no provision for advising complainants of the outcome of an investigation. See id. at 822.

239. See id. at 823 .

240. Dellums consolidated three district court cases on appeal. See id.; see also infra Part IV.D.1 (discussing congressional oversight as an enforcement mechanism).

241. The same result was reached in Beauchamp v. Meese, 657 F. Supp. 1263 (N.D. Ill. 1987), a colorful case in which the plaintiff sued to compel the Attorney General to undertake a preliminary investigation of Judge Sporkin, a federal district judge, for perjury, and the Attorney General and the U.S. Attorney, for conspiracy to obstruct justice in failing to investigate Judge Sporkin. See id. at 1263. The plaintiff claimed that excessive bail had been set for his detention for a misdemeanor; Judge Sporkin denied that he had any knowledge of the plaintiff. See id. The court granted the Attorney General's motion to dismiss, stating that Congress specifically considered proposals that would allow for the private enforcement of the Act, but these proposals had died in the face of arguments that the powers given the congressional judiciary committees provided an adequate check on the Attorney General's discretion and that allowing for public enforcement would lead to misuse and greater public cynicism directed at government officials. See id. at 1264-65 (citing Nathan v. Smith, 737 F.2d 1069, 1080-81 (D.C. Cir. 1984)).

242. See S. REP. No. 100-123, at 15 (1987), reprinted in 1987 U.S.C.C.A.N. 2150, 2164. The provision reads: "The Attorney General's determination under this chapter to apply to the division of the court for the appointment of an independent counsel shall not be reviewable in any court." 28 U.S.C. $\S 592(\mathrm{f})(1994)$. 


\section{Private Citizens Cannot Compel the Special Division to Appoint an} Independent Counsel. In addition to trying to compel the Attorney General to undertake a preliminary investigation, private citizens have sought to compel the Special Division to appoint an independent counsel. Although $\S 592(\mathrm{f})$ states that the courts may not compel the Attorney General to conduct a preliminary investigation or undertake a preliminary investigation, the provision is silent as to suits by citizens against the Special Division itself.

Despite this silence, the courts consistently have rejected these claims, stating that the Act "does not ... confer standing on private citizens to sue the special division to compel it to appoint independent counsels" 243 and that the Special Division is without jurisdiction to act where the Attorney General has not applied for the appointment of an independent counsel. ${ }^{244}$ Furthermore, no court-not just the Special Division-has jurisdiction to appoint an independent counsel at the request of a private citizen because the Act states specifically that only the Attorney General possesses this authority. ${ }^{245}$ In essence, the Act "does not provide an open door for private citizens to compel the investigation of alleged violations of federal law by direct application to the Special Division to appoint independent counsel for that purpose. ${ }^{246}$

In In re INSLAW, ${ }^{247}$ for example, a government contractor applied to the Special Division seeking the appointment of an independent counsel to investigate alleged misconduct in a contract dispute between the contractor and DOJ. ${ }^{248}$ The court held that it had no jurisdiction in the matter because the Attorney General had not applied for the appointment of an independent counsel. ${ }^{249}$ Similarly, in In re Visser, ${ }^{250}$ the plaintiff requested the Special Division to

243. In re Kaminski, 960 F.2d 1062, 1062 (D.C. Cir. 1992) (per curiam). The petitioner in Kaminski sued the Special Division pro se, attempting to force it to receive evidence of misconduct by federal judges under the theory that 28 U.S.C. $\$ 49$ gives the Special Division unqualified authority to appoint independent counsels. See id. at 1062-63.

244. See id. at 1063; cf. United States v. Nixon, 418 U.S. 683, 693 (1974) (stating that "the Executive Branch has exclusive authority and absolute discretion to decide whether to prosecute a case"); Linda R.S. v. Richard D., 410 U.S. 614, 619 (1973) ("[A] citizen lacks standing to contest the policies of the prosecuting authority when he himself is neither prosecuted nor threatened with prosecution.").

For further discussion of the relationship between the Special Division and the independent counsel with respect to jurisdictional issues, see infra Part IV.B.2.

245. See Kaminski, 960 F.2d at 1064-65.

246. Id. at 1064; cf. Linda R.S., 410 U.S. at 619 ("[I]n American jurisprudence ... a private citizen lacks a judicially cognizable interest in the prosecution or non-prosecution of another.").

247. 885 F.2d 880 (D.C. Cir. 1989) (per curiam).

248. See INSLAW, 885 F.2d at 880 . The plaintiff had supplied the information to James C. McKay, the independent counsel charged with investigating Attorney General Meese, but McKay determined that the request for an investigation based on these materials exceeded his jurisdiction and he referred the matter to the Attorney General. See id. at 880-82. DOJ reviewed the material and the allegations, but determined that they were insufficient to warrant a preliminary investigation under $\S 591$ (d) and thus closed the matter. See id. at 881.

249. See id. at 880 . The court reaffirmed the rationale of the Dellums and Banzhaf courts and held that private citizens lacked standing under the Act, even where the allegations concerned were conceded to be "specific and credible." See id. at 882 (citing Dellums v. Smith, 797 F.2d 817, 822 (9th Cir. 1986)). The INSLAW court prudently pointed out that the fact that "the courts are specifically prevented from reviewing the Attorney General's decision not to seek appointment" under the statute helped the Supreme Court in Morrison to uphold the Act as constitutional. Id. at 883. 
appoint an independent counsel to investigate the alleged misconduct of numerous state and federal officials regarding a misdemeanor charge filed against him. ${ }^{251}$ The court held that a plaintiff has no standing to petition the Special Division in the name of the Attorney General and that the court is without jurisdiction to appoint an independent counsel in the absence of an application by the Attorney General. ${ }^{252}$

\section{B. The Relationships Between the Act and the Special Division}

As noted above, the Act establishes a division of the United States Court of Appeals for the District of Columbia Circuit for the purpose of appointing independent counsels. ${ }^{253}$ The Chief Justice of the United States Supreme Court designates and assigns three circuit court judges to the Special Division for renewable two-year terms. ${ }^{254}$ The Act requires that one of the three judges be a judge of the United States Court of Appeals for the District of Columbia Circuit and stipulates that no two of the three judges may be named to the Special Division from a particular court. ${ }^{255}$ The Act further states that the judges of the Special Division are ineligible to participate in any matter relating to an independent counsel they have appointed. ${ }^{256}$

Although the relationship between the independent counsel and the Special Division is a significant one, due to constitutional concerns, this relationship is limited and circumscribed. ${ }^{257}$ Once the Special Division has appointed an independent counsel and defined his or her prosecutorial jurisdiction, it has no

Furthermore, the $I N S L A W$ court held that, under $\S 593(\mathrm{c})(2)$, the forwarding of material by an employee of an independent counsel to DOJ's Public Integrity Section "for such action, if any, that your office may wish to take" did not constitute a formal submission by the independent counsel to the Attorney General under the Act, or even to the Public Integrity Section. Id. (emphasis added).

250. 968 F.2d 1319 (D.C. Cir. 1992) (per curiam).

251. See id. at 1320 .

252. See id. at $1322-23$.

253. See 28 U.S.C. $\$ \S 49$, 593(a) (1994); see also In re A Charge of Judicial Misconduct or Disability, 39 F.3d 374, 378 (D.C. Cir. 1994) ("While nominally a division of the Court of Appeals for the District of Columbia Circuit ..., the Special Division has no functional relationship to the Court of Appeals. The Division keeps its own records and establishes its own procedures."); Niles L. Godes \& Ty E. Howard, Independent Counsel Investigations, 35 AM. CRIM. L. REV. 875, 881-84 (1998) (describing provisions of the Act that establish and define the function of Special Division).

254. Priority in assignment to the Special Division is to be made to retired circuit judges and retired justices. See S. REP. No. 95-170, at 36 (1977), reprinted in 1978 U.S.C.C.A.N. 4216, 4252. Furthermore, "[b]y giving priority to senior retired circuit court judges and senior retired justices, the members of the special division will not be sitting on matters involving the Department of Justice on a dayto-day basis." Id. at 78, reprinted in 1978 U.S.C.C.A.N. at 4294. Interestingly, Congress gave another rationale for utilizing senior judges on the Special Division: Since the Special Division would be dealing with sensitive matters of great concern to the present Administration, "[a]s retired judges their ambitions would have been largely achieved and their activities would be less likely to involve them in any conflict situation." Id.

255. See 28 U.S.C. $\$ 49(1994)$.

256. See id. $\$ 49(\mathrm{f})$.

257. "The Special Division has no authority to take any action or undertake any duties that are not specifically authorized by the Act." Morrison v. Olson, 487 U.S. 654, 684 (1988). 
power to supervise or control his or her activities:" sel does not operate under our supervision and his acts . . . do not bear our aegis." 259

1. The Appointment and Selection of Independent Counsels by the Special Division. On receiving the application for the appointment of an independent counsel from the Attorney General, the Special Division selects the independent counsel for that investigation and defines his or her prosecutorial jurisdiction. ${ }^{260}$ The Act states that the independent counsel is to be a person "who has appropriate experience and who will conduct the investigation and any prosecution in a prompt, responsible, and cost-effective manner."261 Furthermore, the individual selected must have the ability to devote the necessary time to complete an investigation ${ }^{262}$ and cannot simultaneously hold

258. See id. at 695. The fact that the independent counsel is under the control-although perhaps the "control" is nominal and formal at best-of the executive branch was key to the Morrison Court upholding the Act's constitutionality. See id. at 684 ("The gradual expansion of the authority of the Special Division might in another context be a bureaucratic success story, but it would be one that would have serious constitutional ramifications."). A forerunner of Morrison stated that none of the limited powers of the Special Division under the Act impermissibly involved it in the criminal investigation conducted by an independent counsel. See In re Sealed Case, 666 F. Supp. 231, 236 (D. Colo. 1987).

In any event, the Special Division takes its lack of supervisory power seriously: "We get complaints about independent counsel, and we have to explain that we have no supervisory authority and we cannot, without violating the Constitution, exercise supervisory authority, as the Supreme Court has held." See Symposium, supra note 103, at 1542 (statement of Judge John Butzner, Jr.).

259. In re North, 16 F.3d 1234, 1239 (D.C. Cir. 1994); see also In re Sealed Case, 665 F. Supp. 56, 59 (D.D.C. 1987) ("Although the Special Division appoints independent counsels and defines their jurisdiction, it plays no role in their investigations and performs no acts with regard to any prosecutions that may result from these investigations.").

260. See 28 U.S.C. $\S \S 592(c), 593(b)(1)$ (1994). The Morrison Court held that there was no "inherent incongruity about a court having the power to appoint prosecutorial officers." Morrison, 487 U.S. at 676 . When Congress passed the Act, it was concerned about conflicts of interest that could arise when the executive branch was called on to investigate its own high-ranking officers. See id. at 677. If the Court were to remove the authority to appoint an independent counsel from the executive branch, the next most logical place to vest it would be the judicial branch. See id.

The appointment power vested in the Special Division is limited because it extends only to the power to appoint the independent counsel and not his or her team. See Julie O'Sullivan, The Independent Counsel Statute: Bad Law, Bad Policy, 33 Am. Crim. L Rev. 463, 481 (1996). O'Sullivan notes that whom the independent counsel chooses to assist him or her in the investigation is, or should be, an important part of the decision that the Special Division makes in appointing an independent counsel. See id.

261. 28 U.S.C. $\$ 593($ b)(2) (1994). Some light on the selection process of independent counsels was shed at the 67 th Judicial Conference of the Fourth Circuit:

We maintain a talent book, but it is, by no means, exclusive, that contains the names and brief biographies of a large number of attorneys around the country whom we consider as possibilities for independent counsel. Those names can come to us from anywhere-first, from Judge Butzner's institutional memory or our own official institutional memory where we've accumulated names in prior instances.

See Symposium, supra note 103, at 1537 (statement of Judge David Sentelle).

262. The Act is silent as to whether the independent counsel may work part-time on the matter that he or she is charged to investigate. The legislative history to the 1978 Act states that "[t]here is no requirement that service as a special prosecutor be a full time position." S. REP. No. 95-170, at 75 (1977), reprinted in 1978 U.S.C.C.A.N. 4216, 4291. In 1987, Congress rejected a proposal that would have required the independent counsel to work full-time on the matter he or she was charged to inves- 
any other federal office. ${ }^{263}$ Yet the Act is silent about whether or to what extent the Special Division may solicit or consider the views of persons other than its own members. According to current case law, judges on the Special Division may engage in ex parte communications at a time when the Special Division is considering the appointment of an independent counsel. ${ }^{264}$

tigate and prosecute, feeling that such a restriction might deter the best and brightest lawyers from undertaking service as an independent counsel. See H.R. CONF. REP. NO. 100-452, at 26-27 (1987), reprinted in 1987 U.S.C.C.A.N. 2185, 2192-93. But see O'Sullivan, supra note 260, at 481-82 (criticizing the rationale of the House Conference Report and arguing that "[w]ere the statute's coverage confined to cases in which the DOJ genuinely may appear to be conflicted-for example, where the subject is the President or Attorney General-it is difficult to believe that the Special Division could not find outstanding candidates willing to undertake full-time appointment").

In offering an additional rationale for not requiring that the independent counsel serve full time, Congress stated that

the independent counsels should conduct their activities expeditiously and should complete their cases without delay. At the same time ... criminal litigation inevitably entails delays and periods in which counsel will not have sufficient work to attend to the case on a full time basis. ... [T] [Te statute should require independent counsels to devote as much time to their cases as is necessary to move the cases expeditiously to completion.

H.R. CONF. REP. NO. 100-452, at 26, reprinted in 1987 U.S.C.C.A.N. at 2192.

263. See 28 U.S.C. $\S 593$ (b)(2) (1994). Such a requirement comports with the purpose of the Act: "The entire purpose of appointing a temporary special prosecutor is to get someone who is independent, both in reality and appearance, from the President and the Attorney General." S. REP. NO. 95 170, at 65-66 (1977), reprinted in 1978 U.S.C.C.A.N. 4216, 4281-82.

264. See In re A Charge of Judicial Misconduct or Disability, 39 F.3d 374, 381 (D.C. Cir. 1994). According to a newspaper report, Judge Sentelle had met with North Carolina Republican Senators Jesse Helms and Lauch Faircloth while the Attorney General's application for an independent counsel was pending; the Special Division soon thereafter appointed Ken Starr as independent counsel in the Whitewater investigation. See id. at 377. Notably, the court did not decide whether a member of the Special Division was subject to disciplinary proceedings in the D.C. Circuit Court of Appeals because the judge against whom disciplinary proceedings were sought did not contest the disciplinary jurisdiction of the circuit. See id. at 378. But see Peter M. Ryan, Comment, Counsels, Councils, and Lunch: Preventing Abuse of the Power to Appoint Independent Counsels, 144 U. PA. L. REV. 2537, 2552 (1996) (arguing that although two members of the Special Division are not from the D.C. Circuit, Judge Sentelle was and therefore should be subject to disciplinary proceedings in his home circuit). Ryan maintains that under the view taken by the D.C. Circuit, the only way to prevent the abuse of the appointment power by judges on the Special Division is to amend the Act so as to restrict their discretion. See Ryan, supra, at 2555 . He suggests, in the alternative, that the Judicial Conduct Act, 28 U.S.C. $\$ \S 331$ $332,372,604$ (1994), should apply to members of the Special Division, despite the fact that the Special Division exercises Article II, not Article III, power in the appointment of independent counsels. See Ryan, supra, at 2543.

However, the rationale for the result reached by the D.C. Circuit-a result that would seriously compromise the integrity of the tribunal were it serving in a judicial capacity-is precisely because, when appointing an independent counsel, the Special Division draws its authority not from Article III of the Constitution (which establishes and defines the judicial branch) but rather from the Appointments Clause of Article II: "Congress may by Law vest the Appointment of such inferior Officers, as they think proper, in the President alone, in the Courts of Law, or in the Heads of Departments." U.S. CoNST. art. II, § 2; see also In re Sealed Case, 665 F. Supp. 56,58 (D.D.C. 1987) (discussing the Special Division's appointment of independent counsels as being the exercise of Article II, not Article III, power). There are no constitutional or ethical precepts that prohibit Presidents, judges, or heads of departments from consulting with others in exercising their Article II power. See Judicial Misconduct or Disability, 39 F.3d at 375. See generally O'Sullivan, supra note 260, at 473 (describing the meetings between Judge Sentelle and the senators prior to the appointment of Ken Starr and the resulting court case, and discussing its impact on the vitality of the independent counsel statute); Nick Bravin, Note, $I s$ Morrison v. Olson Still Good Law? The Court's New Appointments Clause Jurisprudence, 98 CoLUM. L. REV. 1103, 1126-27 (1998) (same); Ryan, supra, at 2537-39 (1996) (same). Arguably, the exercise of 
2. Defining the Independent Counsel's Jurisdiction. The office of independent counsel is of limited jurisdiction. ${ }^{265}$ Once the Special Division appoints an independent counsel, the Act states that the Special Division "shall define that independent counsel's prosecutorial jurisdiction." ${ }^{266}$ This jurisdiction includes the "authority to investigate and prosecute Federal crimes ... that may arise out of the investigation or prosecution of the matter. ${ }^{267}$ The Special Division is also required to define the independent counsel's prosecutorial jurisdiction so that the independent counsel has "adequate authority to fully investigate and prosecute the subject matter with respect to which the Attorney General has requested the appointment of the independent counsel, and all matters related to that subject matter.",268

The Supreme Court has held that

Congress may [not] give the Division unlimited discretion to determine the independent counsel's jurisdiction. In order for the Division's definition of the counsel's jurisdiction to be truly "incidental" to its power to appoint, the jurisdiction that the court decides upon must be demonstrably related to the factual circumstances that gave rise to the Attorney General's investigation and request for the appointment of the independent counsel in the particular case. ${ }^{269}$

Nevertheless, the broad statutory grant of power to the Special Division to determine the prosecutorial jurisdiction enables the Special Division to vest a great deal of authority in the independent counsel. This comports with the purpose of the Act in ensuring that high-level executive branch officials do not have the ability to investigate themselves or those to whom they are beholden.

the Appointments power by the Special Division should not differ in form or function from that of any member of the executive branch eligible to exercise such power.

265. See Morrison, 487 U.S. at 672. This fact aided the Morrison Court in determining that the independent counsel was an inferior officer and thus that the Act was constitutional. See id.; see also Sealed Case, 665 F. Supp. at $59 \mathrm{n} .2$ (stating that independent counsel has no authority outside the jurisdiction established by the Special Division). Indeed, Congress commented in passing the Act in 1978 that "[ $t$ ]he prosecutorial jurisdiction of the special prosecutor is one of the most important devices for the control of the special prosecutor and the accountability of such a special prosecutor." S. REP. No. 95-170, at 56 (1977), reprinted in 1978 U.S.C.C.A.N. 4216, 4272.

266. 28 U.S.C. $\$ 593(b)(1)$ (1994). The Morrison Court held that it was not outside the Special Division's Appointments Clause powers to define the independent counsel's jurisdiction. See Morrison, 487 U.S. at 679.

267. 28 U.S.C. § 593(b)(3) (1994).

268. Id. The Special Division does, despite Morrison's limitations, have some discretion in determining the prosecutorial jurisdiction of the independent counsel. The Act does not require the Special Division "to adopt verbatim the recommendations of the Attorney General in defining independent counsel's jurisdiction." United States v. North, 708 F. Supp. 387, 388 (D.D.C. 1988). The court in North emphasized that Morrison gave the Special Division "leeway to grant the Independent Counsel jurisdiction that was demonstrably related to that proposed by the Attorney General." Id. In North, the defendant had sought to have the indictment against him dismissed, arguing that the independent counsel lacked prosecutorial jurisdiction because the charges fell outside the area authorized by the Attorney General in his request to the Special Division for the appointment of an independent counsel. See id. at 387-88.

269. Morrison, 487 U.S. at 679 . To meet the "related to" test, there need only be a showing of a reasonable causal or logical connection between two occurrences. See United States v. Secord, 725 F. Supp. 563, 567 (D.D.C. 1989). However, Morrison held that the relationship must be demonstrable, see Morrison, 487 U.S. at 679 , meaning that it must be something that is evident without "great leaps of logic." See Secord, 725 F. Supp. at 567. 
Finally, the Special Division's responsibility in defining the prosecutorial jurisdiction of an independent counsel is a continuing one. ${ }^{2 \pi}$ That is, even if the Attorney General does not request that related matters be assigned to an existing independent counsel, the Special Division has the authority to do so under $\S 593(\mathrm{~b})$. $^{271}$

On initial inspection, the jurisdictional provisions of the Act might not appear to create any significant problems. Congress thought it had succinctly summarized the functioning of these jurisdictional provisions during the Act's 1994 reenactment:

[W] hen an independent counsel is confronted with new information about a criminal allegation involving a covered individual, depending upon the extent to which the matter may or may not fall within the independent counsel's original grant of jurisdiction, he or she must follow one of two procedures. For related matters, he or she must apply to the special court or ask the Attorney General for a referral of such matter pursuant to the jurisdiction originally set by the special court (or the Attorney General may refer such matter to the independent counsel on the Attorney General's own initiative). For matters outside the scope of the independent counsel's jurisdiction, he or she must forward the information to the Attorney General for the conduct of a preliminary investigation which could result in the expansion of that independent counsel's jurisdiction or the appointment of a new independent counsel. ${ }^{272}$

Distinguishing between "expansion" and "referral" jurisdiction-determining the meaning of "matters outside the scope of the independent counsel's jurisdiction" or "related matters"-may be drawing a distinction without a difference and has led to much litigation and criticism from numerous commentators. $^{273}$

a. Expansion of the independent counsel's jurisdiction. During the course of an investigation, an independent counsel may seek the expansion of his or her prosecutorial jurisdiction to include matters that are outside the scope of the initial grant of jurisdiction. ${ }^{274}$ To have his or her prosecutorial jurisdiction expanded, the independent counsel must first submit the new information to the Attorney General, who, upon its receipt, must conduct a preliminary investigation. ${ }^{275}$ If the Attorney General determines that an independent counsel investigation of the matter is necessary, the Special Division could

270. See S. REP. NO. 95-170, at 65 (1977), reprinted in 1978 U.S.C.C.A.N. 4216, 4281.

271. See id.

272. H.R. CONF. REP. NO. 100-452, at 29 (1987), reprinted in 1987 U.S.C.C.A.N. 2185, 2195.

273. See, e.g., Symposium, supra note 103, at 1530-31, 1534 (statements of William Barr and Jamie Gorelick).

274. See 28 U.S.C. § 593(c) (1994). The Morrison Court held that, just as the power to define the independent counsel's jurisdiction is incidental to the Special Division's power to appoint the independent counsel, so too is the power of the Special Division to expand the jurisdiction of the independent counsel upon request of the Attorney General. See Morrison, 487 U.S. at 679 n.17.

275. See 28 U.S.C. $\$ 593(c)(2)(1994)$. This preliminary investigation is the same as that conducted under $\S 592$, except that it may last a maximum of 30 days. See id. $\S 593$ (c)(2)(A); cf. supra Part III.B.3 (discussing the preliminary investigation). 
expand the existing independent counsel's jurisdiction or could appoint a new independent counsel. $^{276}$

In determining the need for expanded jurisdiction, the Attorney General is to give "great weight" to the recommendations of the independent counsel. ${ }^{277}$ If, after the preliminary investigation, the Attorney General finds no reasonable grounds for further investigation, he or she shall notify the Special Division, which, under those circumstances, lacks the power to expand the independent counsel's jurisdiction. ${ }^{278}$ However, if the Attorney General finds reasonable grounds for further investigation, or if the Attorney General fails to notify the Special Division of the results of the preliminary investigation within thirty days, then the Act directs the Special Division to expand the prosecutorial jurisdiction of the independent counsel to include the new matters. ${ }^{279}$ Most importantly, the Special Division may not expand the jurisdiction of the independent counsel if the Attorney General refuses to request the expansion. ${ }^{280}$

b. The referral of other matters to an independent counsel. Unlike expansion jurisdiction, referral jurisdiction involves the interpretation-but not the outward expansion-of the independent counsel's original jurisdiction. ${ }^{281}$ Because "interpretation" and "expansion" are not cleanly defined or mutually exclusive categories, much debate has centered on the proper handling by the Special Division of requests for changes in the independent counsel's jurisdiction. $^{282}$ Most of the focus of the courts and commentators involves referral jurisdiction.

276. See 28 U.S.C. § 593(c)(1) (1994).

277. See id. \$ 593(c)(2); see also Russell M. Soloway, Note, The Tale of the Omnipotent Prosecutor: How Recent Events Expose Flaws in the Supreme Court's Analysis of the Independent Counsel Clause of the Ethics in Government Act, 17 REV. LiTIG. 611, 628 (1998) ("Both the IC and the courts have loosely interpreted broad initial grants of jurisdiction. Additionally, in a politically charged atmosphere, it has proven unrealistic for the Attorney General to deny a request for expansion of jurisdiction of the IC.").

278. See 28 U.S.C. § 593(c)(2)(B) (1994).

279. See id. $\$ 593(\mathrm{c})(2)(\mathrm{C})$.

280. See In re Sealed Case, 665 F. Supp. 56, 60 n.4 (D.D.C. 1987). The 1987 amendments changed the provisions in the Act relating to the expansion of an independent counsel's prosecutorial jurisdiction: Independent counsels became required to present all requests for expansions of their jurisdiction to the Attorney General. See S. REP. NO. 100-123, at 24 (1987), reprinted in 1987 U.S.C.C.A.N. 2150, 2173.

By lodging final decisionmaking authority with the Attorney General, but also requiring the Attorney General to give "great weight" to the recommendations of the sitting independent counsel, the [Act] establishes a process by which a request for expanded jurisdiction is handled not only within the constraints of the Constitution, but also with assurance that the independent counsel is given a meaningful role in the decisionmaking process.

Id. The issue of requests for the expansion of jurisdiction was much on the mind of Congress in 1987 because of the refusal of Attorney General Meese to request an independent counsel in the Environmental Protection Agency case to investigate Edward Schmults and Carol Dinkins, despite the Public Integrity Section's recommendation to do so. See id. at 12, reprinted in 1987 U.S.C.C.A.N. at 2161.

281. See In re Espy, 80 F.3d 501, 506 (D.C. Cir. 1996) (per curiam); Godes \& Howard, supra note 253 , at 885 .

282. Contemplating the issue of referral jurisdiction, the Senate Report noted in enacting the original Act, "there will have to be coordination between the special prosecutor and the Attorney General to sort out the jurisdiction of the special prosecutor as it relates to the ongoing investigations of the 
During the course of an investigation, the independent counsel may have matters related to the investigation referred to him or her by DOJ or another entity, or the independent counsel may request that the Attorney General or the Special Division refer matters related to his or her jurisdiction. ${ }^{283}$ The independent counsel may accept a referral if it is related to his or her prosecutorial jurisdiction, but the subject matter of the referral jurisdiction need not meet the same standard of relatedness to the factual circumstances as does the subject matter of the original prosecutorial jurisdiction. ${ }^{284}$ Referral jurisdiction depends on the procedural and factual nexus between the independent counsel's original prosecutorial jurisdiction and the matter that is to be referred.

Before the 1994 revision of the Act, if the new matter was related to the independent counsel's prosecutorial jurisdiction, he or she was required to ask the Attorney General or the Special Division to refer it to him or her formally. ${ }^{286}$ However, if the new matter was related to the subject matter of the Attorney General's original request for appointment, the independent counsel could proceed on his or her own. ${ }^{287}$ In January 1987, Independent Counsel Morrison asked the Attorney General pursuant to $\S 594(\mathrm{e})$ to refer to her as "related matters" several allegations. ${ }^{288}$ When the Attorney General refused to refer the matters, the Independent Counsel asked the Special Division to order that the matters be referred to her. ${ }^{289}$ Although the Supreme Court held that the Attorney General's decision whether to seek an independent counsel is unreviewable under § 592(b)(1), it found that the Special Division's original grant of jurisdiction was broad enough to encompass the inquiry into whether the subject of the investigation had conspired with others to commit a crime. ${ }^{290}$

Department of Justice." S. REP. NO. 95-170, at 69 (1977), reprinted in 1978 U.S.C.C.A.N. $4216,4285$. Furthermore, Congress noted that "[t]he other side of this necessary cooperation will take place under subsection 597 (a) which permits the special prosecutor to agree in writing that certain portions of the investigations assigned to him by the division of the court continue to be conducted by the Department of Justice." See id.

283. See 28 U.S.C. \$ 594(e) (1994). Section 594(e) gives an independent counsel the choice between asking the Attorney General or the Special Division for referral of a related matter and further states that the Attorney General or the Special Division may refer such matter to the independent counsel. See id. To challenge the statutory authority of the Special Division to grant an order of referral for the prosecution of an individual not a subject of the original grant of jurisdiction to the independent counsel, the individual must identify some act of the Special Division that is not authorized by the Act. See United States v. Wade, 83 F.3d 196, 198 (8th Cir. 1996) (per curiam).

284. See Espy, 80 F.3d at 508.

285. See United States v. Tucker, 78 F.3d 1313, 1321 (8th Cir.), cert. denied, 117 S. Ct. 76 (1996).

286. See United States v. Secord, 725 F. Supp. 563, 566 (D.D.C. 1989).

287. See id.

288. See Morrison v. Olson, 487 U.S. 654, 667 (1988).

289. See id. at 668 .

290. The Special Division had ordered that the independent counsel "shall have jurisdiction to investigate any other allegation of evidence of violation of any Federal criminal law by The odore Olson developed during investigations, by the Independent Counsel, referred to above, and connected with or arising out of that investigation, and Independent Counsel shall have jurisdiction to prosecute for any such violation."' Id. at 667 (quoting Order, Div. No. 86-1 (D.C. Cir. Apr. 23, 1986)). "As to the Division's alleged 'reinterpretation' of its original grant of jurisdiction, the power to 'reinterpret' or clarify the original grant may be seen as incidental to the court's referral power." Id. at 685 n.22. 
In deciding this same issue, the Special Division ${ }^{291}$ had noted that the provisions of $\S \S 594(\mathrm{e})$ and 592(b)(1) must be read together. It also noted that it would be "highly unreasonable" to interpret the Act as requiring the Attorney General or empowering the Special Division to refer a matter to the independent counsel when the Attorney General had determined that there were "no reasonable grounds to believe that further investigation or prosecution is warranted. ${ }^{, 292}$ The Supreme Court held, however, that $\S 594(\mathrm{e})$ does not give the Special Division the authority to refer allegations to the independent counsel when the Attorney General has determined specifically under $\$ 592(b)(1)$ that those allegations should not be pursued. ${ }^{293}$

More recently, the Eighth Circuit added to the debate and confusion when it handed down United States $v$. Tucker. ${ }^{294}$ By holding that a grant of referral jurisdiction is nonreviewable, ${ }^{295}$ the Eighth Circuit effectively extended the reach of the independent counsel's prosecutorial jurisdiction, allowing that jurisdiction to reach private citizens. ${ }^{296}$ In reaching this conclusion, the court made a broad comparison between referral jurisdiction and prosecutorial dis-

291. In re Olson, 818 F.2d 34 (1987) (per curiam).

292. Id. at 47. The Attorney General had determined twice that there were no reasonable grounds to believe that further investigation or prosecution was warranted. See id.

The case arose when Independent Counsel Morrison, investigating allegations that Olson perjured himself during a congressional inquiry into the Superfund toxic waste program, requested that the Attorney General refer to her the allegations in a congressional report against two other individuals, claiming under $\S 594(\mathrm{e})$ that the allegations were "related matters" to her investigation of Olson. See id. at 37. The Attorney General refused to grant Morrison the authority to investigate the others, stating that he had already determined there were no reasonable grounds for further investigation. See id. at 38. The Independent Counsel thereupon applied to the Special Division for referral of the allegations. See id.

293. See id. at 47. The court nevertheless held that the independent counsel had the authority to investigate allegations that Olson was engaged in an unlawful conspiracy with others. See id. Although the independent counsel thus would be permitted to investigate the actions of others, her jurisdiction permitted her only to prosecute Olson. See id. at 48.

294. 78 F.3d 1313 (8th Cir.), cert. denied, 117 S. Ct. 76 (1996).

295. See id. at 1316. The Tucker court held that even if such a grant were reviewable, there was no abuse of discretion by the Attorney General because "the subject matter of the referral jurisdiction in this case was 'related' to the Independent Counsel's original prosecutorial jurisdiction ...." Id. at 1322; see also United States v. Wade, 83 F.3d 196, 198 (8th Cir. 1996) (per curiam) (stating that the court lacked jurisdiction to review Wade's argument that his prosecution is not related to the Special Division's original grant of authority to the independent counsel).

296. See Tucker, 78 F.3d at 1322. For recent commentary on Tucker arguing that such an extension of the independent counsel's referral jurisdiction and reach of its powers subverts the original purpose of the Act and is unfair to the subject of the investigation, see Hanly A. Ingram, Note, United States v. Tucker: Should Independent Counsels Investigate and Prosecute Ordinary Citizens?, 86 KY. L.J. 741 (1997). See also Recent Case: Statutory Interpretation-Ethics in Government Act-Eighth Circuit Holds Attorney General's Referral of Matters to Independent Counsel to Be Nonreviewable, 110 HARV. L. REV. 793 (1997); Soloway, supra note 277, at 629 ("This decision essentially eviscerated the Morrison 'demonstrably related' test by eliminating the requirement that the expansion of jurisdiction be related to the IC's original grant. Instead, it created an expansive jurisdiction for the IC, through referral jurisdiction and a broad reading of the original grant.").

In Independent Counsel Starr's latest expansion of jurisdiction, he began to investigate the allegations involving the President and Monica Lewinsky even before applying for an extension from the Attorney General and the Special Division. See id. at 631-32 (citing news media sources). As this Symposium goes to print, this expansion of jurisdiction is the subject of a possible investigation by DOJ. See infra text accompanying note 421. 
cretion, stating that "prosecutorial decisions of the nature here in questionwho should be prosecuted and for what alleged crimes-have long been committed to the discretion of the prosecutor. ${ }^{297}$

The result of Tucker was the explicit recognition that both the Attorney General and an independent counsel are allowed broad discretion in dealing with matters of referral jurisdiction. Significantly, the Eighth Circuit did not apply the "demonstrably related" standard that the Supreme Court provided in Morrison. Rather, the court fashioned its own "procedural and factual link" definition of "relatedness," stating that the "demonstrably related" standard applies only when defining an independent counsel's prosecutorial jurisdiction in the first instance. ${ }^{298}$ In the end, the court found that Tucker's case was "related" to the Whitewater scandal. ${ }^{299}$

The same analysis was applied when Independent Counsel Donald Smaltz $z^{300}$ submitted an application for the referral of a related matter and DOJ opposed the application because it felt that $\S 594$ (e) must be read to require the concurrence of the Attorney General before the Special Division could refer matters to the independent counsel. ${ }^{301}$ The Special Division held that the plain language of $\S 594$ (e) did not suggest that the Attorney General was required to concur in the referral of a matter to the independent counsel before the Special Division could grant an application for referral. ${ }^{302}$ The court distinguished the

\section{Tucker, 78 F.3d at 1317.}

298. See id. at 1320. But, $\S 594$ (e) allows the Attorney General to refer a matter to the independent counsel without the approval of the Special Division. Given that the Act states that only the Special Division may define an independent counsel's prosecutorial jurisdiction, the only grant of jurisdiction that can apply to a referred matter is the original grant. Section 593(c) provides for the expansion of an independent counsel's original jurisdiction. The Court in Morrison stated that only $\S 593(\mathrm{c})$-not $\S$ 594(e) referral jurisdiction-can be used to expand the Special Division's original grant of prosecutorial jurisdiction. See Morrison, 487 U.S. at 680 n.18. Since a matter referred under $\S 594$ (e) may not expand jurisdiction, it must fall under the original grant and, therefore, must be "demonstrably related to the factual circumstances that gave rise to the Attorney General's . . request" for the appointment of an independent counsel. See id. at 679.

299. See Tucker, 78 F.3d at 1320 . "[R]elatedness for purposes of referral under $\S 594(\mathrm{e})$ depends upon the procedural and factual link between the OIC's original prosecutorial jurisdiction and the matter being referred." Id. at 1321; see also In re Espy, 80 F.3d 501, 507-08 (D.C. Cir. 1996) (per curiam) (adopting this definition of "relatedness"). The Espy court held that the matter was sufficiently related to permit referral where Independent Counsel Smaltz maintained that the referral matter directly overlapped his current jurisdiction

in terms of persons involved, witnesses, patterns of conduct, and applicable law, and that the factual basis of the referral matter arose directly from his investigation of whether Secretary

Espy violated any federal criminal law relating in any way to the acceptance of gifts by him from organizations or individuals with business pending before the Department of Agriculture.

Id. at 508 .

300. Independent Counsel Donald C. Smaltz was charged with investigating whether Secretary of Agriculture Mike Espy violated federal criminal law by accepting gifts from organizations or individuals involved in business with the Department of Agriculture. See id. at 502-03.

301. See id. at 504 . DOJ also argued that the new matter was not sufficiently related to the independent counsel's current prosecutorial jurisdiction. See id.

302. See id. at 505. The court held that the use of the disjunctive "or" in the statute made it plain that Congress intended for alternative, independent mechanisms through which a matter could be re- 
referral of a matter from the expansion of the independent counsel's jurisdiction and stated that, in referring a related matter, the court is interpreting-but not expanding - the independent counsel's original prosecutorial jurisdiction. ${ }^{303}$

Thus, the issues of expansion and referral jurisdiction are complicated and unresolved. As the Act currently stands, there is no clear line or rule for distinguishing referral from expansion jurisdiction. The issue is an important one: To have a matter referred to him or her, an independent counsel can choose to go to either the Special Division or the Attorney General. But to have his or her jurisdiction expanded to include a matter outside that jurisdiction, an independent counsel must seek authorization from the Attorney General. Whether the courts or Congress can clarify this distinction and thus minimize the litigation over this issue in the future remains to be seen.

3. The Termination of the Independent Counsel by the Special Division. The office of independent counsel is limited in tenure. ${ }^{304}$ The Act provides that

[t] he [special] division of the court, either on its own motion or upon the request of the Attorney General, may terminate an office of independent counsel at any time, on the ground that the investigation of all matters within the prosecutorial jurisdiction of such independent counsel ... have been completed or so substantially completed that it would be appropriate for the Department of Justice to complete such investigations and prosecutions.... If the Attorney General has not made a request under this paragraph, the division of the court shall determine on its own motion whether termination is appropriate... no later than two years after the appointment of an independent counsel, at the end of the succeeding 2-year period, and thereafter at the end of each succeeding 1-year period. ${ }^{305}$

ferred to the independent counsel or by which the independent counsel could seek the referral of a matter related to his or her original prosecutorial jurisdiction. See id.

The court noted that the previous version of $\$ 594$ (e) stated that the independent counsel "may ask the Attorney General or the division of the court to refer matters related to the independent counsel's jurisdiction." Id. at 506 (quoting 28 U.S.C. $\$ 594$ (e) (1982)). Congress amended this sentence by adding "and the Attorney General or the division of the Court, as the case may be, may refer such matters." Id. at 506 (quoting 28 U.S.C. $\$ 594(\mathrm{e})(1994)$ ). The amendment clarified that to obtain expanded jurisdiction over unrelated matters not covered by the original grant of prosecutorial jurisdiction, the independent counsel must follow the procedures and requirements of $\$ 593(\mathrm{c})(2)$, discussed infra Part IV.B.2.a, and submit the information to the Attorney General who then is charged with conducting a preliminary investigation. See id. However, matters that are related to the independent counsel's prosecutorial jurisdiction are governed by $\S 594(\mathrm{e})$, where the independent counsel may either ask the Attorney General or the Special Division for a referral. See id. For criticism of this distinction, see O'Sullivan, supra note 260 , at $486-88$ (stating that a matter appears to be "'related' simply when it comes to the IC's attention during the course of his investigation and involves similar witnesses, alleged patterns of conduct and applicable law").

303. See Espy, 80 F.3d at 507.

304. See Morrison v. Olson, 487 U.S. 654, 672 (1987). This fact aided the Morrison Court in determining that the independent counsel was an inferior officer and thus enabling it to uphold the constitutionality of the Act. See id.

305. 28 U.S.C. $\& 596(\mathrm{~b})(2)$ (1994). The provision calling for the evaluation by the Special Division was added in 1994. See Independent Counsel Reauthorization Act of 1994, Pub. L. No. 103-270, 108 Stat. 732.

The purpose of this provision is to ensure that the special court inquires on a periodic basis, with respect to each independent counsel, as to whether that independent counsel's work is complete. It is not intended to establish deadlines for the completion of this work. Nor is it intended to provide the special court with new termination authority that did not exist at the time the law was reviewed by the Supreme Court in Morrison v. Olson.... The sole purpose 
These termination provisions played a significant role in the decision upholding the constitutionality of the Act. In Morrison v. Olson, the Supreme Court found that the Special Division's power to terminate the independent counsel was not an encroachment on either the executive power or the prosecutorial discretion of the independent counsel:

The termination provisions of the Act do not give the Special Division anything approaching the power to remove the counsel while an investigation or court proceeding is still underway-this power is vested solely in the Attorney General. . . . So construed, the Special Division's power to terminate does not pose a sufficient threat of judicial intrusion into matters that are more properly within the Executive's authority to require that the Act be invalidated as inconsistent with Article III. ${ }^{306}$

Furthermore, in emphasizing the limited powers of the Special Division, the Morrison Court wrote that

the Special Division has no authority to take any action or undertake any duties that are not specifically authorized by the Act. The gradual expansion of the authority of the Special Division might in another context be a bureaucratic success story, but it would be one that would have serious constitutional ramifications. ${ }^{307}$

The Morrison Court also noted in defining the narrow nature of the Act's termination provisions that

\footnotetext{
"termination" may only occur when the duties of the counsel are truly "completed" or "so substantially completed" that there remains no need for any continuing action by the independent counsel... [Termination] is basically a device for removing from the public payroll an independent counsel who has served his or her purpose, but is unwilling to acknowledge the fact. ${ }^{308}$
}

In spite of the significance of the Act's termination provisions, issues involving those provisions have been litigated only rarely since Morrison. And where the termination provisions were at issue in court, it was in a limited context that did not implicate any constitutional issues. In the termination of Independent Counsel Walsh's office, the Special Division had to determine whether, with only Walsh's final report remaining to be completed, the conditions for termination as outlined by $\S 596(\mathrm{~b})(2)$ had been met. ${ }^{309}$ Instead of issuing an order of termination, the Special Division issued an order limiting the scope of Walsh's official activities to duties that related to the task of filing the final report required by $\S 594(\mathrm{~h})(2) .^{310}$ This restriction did not permit Walsh

of this new provision is to ensure that the special court exercises its Constitutionally-defined authority on a periodic basis.

H.R. CONF. REP. No. 103-511, at 23 (1994), reprinted in 1994 U.S.C.C.A.N. 792, 806.

306. Morrison, 487 U.S. at $682-83$.

307. Id. at 684 .

308. Id. at $682-83$.

309. See In re Oliver L. North, 10 F.3d 831, 832 (D.C. Cir. 1993) (per curiam) (stating " that the investigation of all matters within the prosecutorial jurisdiction of [the] Independent Counsel ... and any resulting prosecutions, have been compieted or so substantially completed, that it would be appropriate for the Department of Justice to complete' them" (quoting 28 U.S.C. $\$ 596(\mathrm{~b})(2)$ )).

310. See id. at 834; see also infra Part IV.D.1 (discussing congressional oversight and the final report). 
the authority to amend the report or add comments in response to comments filed by those mentioned in the report. ${ }^{311}$

The termination provisions of the Act were challenged again in United States $v$. McDougal. ${ }^{312}$ In that case, the defendant argued that the 1994 amendment to $\$ 596(\mathrm{~b})(2)$, which required the Special Division to determine periodically whether termination was warranted, ${ }^{13}$ granted the Special Division more power than is constitutionally permissible under Morrison, in that the new provision "compromises the independence of the judiciary and exceeds the limits of article III.", 314 The defendant argued that $\S 596(\mathrm{~b})(2)$ effectively gave the Special Division the power to participate in the investigations of independent counsels.

The McDougal court held that the sentence added to $\S 596(\mathrm{~b})(2)$ by the 1994 amendments did not confer any additional powers on the Special Division because the 1987 revisions already had conferred the power to terminate the independent counsel. ${ }^{315}$ In reaching this conclusion, the court noted that

the 1994 revision simply authorizes the Special Division to check at specified intervals without making any changes in the scope of that power and in the prerequisites to its exercise. The Government argues persuasively that, "the new sentence speaks of 'termination ... under this paragraph,' referring back to the unchanged language of the 1987 Act." In the 1994 Act as in the 1987 one, "the termination provisions ... do not give the Special Division anything approaching the power to remove the counsel while an investigation or court proceeding is still under way." "316

311. See In re North, 10 F.3d at 834. The dissent noted that the independent counsel should have the opportunity to respond, and that by denying him this opportunity,

this court is construing the statute as permitting it to exercise supervision and control over the Independent Counsel in performance of his duty to report "fully and completely" his activities pursuant to $\S 594(\mathrm{~h})(1)(\mathrm{B})$. This court's assumption of power is contrary to the Supreme Court's construction of the statute in Morrison. Prohibiting the Independent Counsel from responding raises a serious constitutional issue under the separation of powers doctrine.

Id. at 837 (Butzner, J., dissenting). Judge Butzner further pointed out that "[ $\mathrm{t}] \mathrm{h}$ statute does not give this court authority to terminate the Independent Counsel's office piecemeal by picking and choosing what duties regarding his report the Independent Counsel shall perform or by ordering how he shall perform them." Id. But see S. REP. No. 95-170, at 75 (1977), reprinted in 1978 U.S.C.C.A.N. 4216, 4291 ("[T]he fact that there is a relatively small amount of work left to be accomplished should not be the motivating factor for terminating an office of special prosecutor. The motivating factor should be the nature of the responsibilities which remain to be carried out by that office.").

Walsh also had asked the Special Division for the authority to respond to further inquiries from the court regarding the report, a possibility that the Court's order did not foreclose. See In re North, 10 F.3d at 834 .

312. 906 F. Supp. 494 (E.D. Ark. 1995).

313. See S. REP. NO. 103-101, at 33 (1993), reprinted in 1994 U.S.C.C.A.N. 748. 778. The purpose of the added provision was to ensure that there was some mechanism for determining whether the independent counsel had completed his or her work, independent of the Attorney General's authority to trigger such an inquiry under the section.

314. McDougal, 906 F. Supp. at 496 (quoting an unidentified source).

315. See id. at 497. McDougal also held that $\S 594(l)(2)$, which provides for administrative services to be provided to the independent counsel by the Director of the Administrative Office of the United States Courts, does not materially and significantly implicate the separation of powers doctrine. See id. at 498.

316. Id. at 497 (quoting Morrison v. Olson, 487 U.S. 654, 682 (1988)). 
Thus, because of constitutional concerns, courts have limited the scope of these provisions. Termination, although largely an administrative role for the court, plays a central role in the relationship between the Special Division and the independent counsel.

\section{The Relationships Between the Independent Counsel and the Department of Justice}

\section{1. "All investigative and prosecutorial functions of the Department of Justice} and the Attorney General." Section 594 of the Act vests the independent counsel with broad authority to investigate and prosecute those matters that fall within his or her jurisdiction. According to the Act, the independent counsel has "full power and independent authority to exercise all investigative and prosecutorial functions and powers of the Department of Justice, the Attorney General, and any other officer or employees of the Department of Justice. ${ }^{317}$ Section 594 transfers to the independent counsel powers that ordinarily belong to both the Attorney General and DOJ. ${ }^{318}$ However, the Act also leaves specified powers firmly within the control of DOJ and the Attorney General. ${ }^{319}$ For example, in its broad grant of litigation authority to the independent counsel, ${ }^{320}$ the statute permits the Attorney General and the Solicitor General to appear as amici curiae to any court as to issues raised in any case brought by an independent counsel. ${ }^{321}$ Furthermore, only the Attorney General may remove an independent counsel from office, ${ }^{322}$ and the

317. 28 U.S.C. $₹ 594$ (a) (1994). The independent counsel is empowered to (1) conduct grand jury and other investigative proceedings; (2) engage in the litigation of other related criminal or civil matters; (3) appeal court decisions; (4) review all documentary evidence available from any source; (5) determine whether to contest the assertion of any testimonial privilege; (6) receive appropriate national security clearances and, where necessary, contest in court any claim of privilege or attempt to withhold evidence on grounds of national security; (7) make applications for grants of immunity to any witnesses, or for warrants, subpoenas, or other court orders; (8) inspect, obtain, or use tax returns; (9) initiate and conduct prosecutions and frame and sign indictments and file informations; and (10) consult with the U.S. Attorney for the district in which any violation of law with respect to which the independent counsel is appointed was alleged to have occurred. See id. § 594(a)(1)-(10); see also Godes \& Howard, supra note 253, at 884-87 (describing the provisions of the Act that delineate the investigatory powers of the independent counsel).

318. See S. REP. NO. 95-170, at 67 (1977), reprinted in 1978 U.S.C.C.A.N. 4216, 4283 ("This catchall phrase and this entire subsection [\$594] should be interpreted to give the special prosecutor any and all independent power and authority which is needed to conscientiously conduct an investigation which is in reality and in appearance independent from any control or supervision by the Department of Justice."). For recent scholarship discussing the relationship between the independent counsel and DOJ, see John Q. Barrett, All or Nothing, or Maybe Cooperation: Attorney General Power, Conduct, and Judgment in Relation to the Work of an Independent Counsel, 49 MERCER L. REV. 519 (1998).

319. See generally Barrett, supra note 318 , at 528-29 (discussing the reservation of powers to the Attorney General and DOJ).

320. See, e.g., 28 U.S.C. § 594(a)(1)-(3), (9) (1994).

321. See id. \&597(b).

322. See id. $\$ 596($ a)(1). The independent counsel also may be removed from office by impeachment and conviction by Congress. See id. The removal provisions of the Act are discussed infra Part IV.C.5. 


\section{Attorney General retains decisionmaking power regarding issues of electronic surveillance and wiretaps. ${ }^{323}$}

Several other powers remain somewhat open to question. The Act does not address DOJ's traditional power to provide legal advice and even legal representation to entities and officials in the executive branch. ${ }^{324}$ Additionally, Attorneys General have insisted that they retain the power to decide whether and how the authority and the personnel of the Office of the Solicitor General will be deployed in appellate litigation involving an independent counsel. ${ }^{325}$ Finally, there is a serious question regarding the independent counsel's ability to stand in the place of the Attorney General with respect to the declassification of information needed in a criminal trial. ${ }^{326}$

\section{Cooperation Between the Independent Counsel and DOJ. Once an} independent counsel's jurisdiction has been defined, the Attorney General and DOJ are required to cease investigations and proceedings regarding the matters covered by that jurisdiction. ${ }^{327}$ The only exceptions to this requirement are circumstances when the independent counsel has requested assistance from DOJ or has stated in writing that DOJ may continue investigations or proceedings on its own. ${ }^{328}$ Nevertheless, the Act expressly permits certain types of cooperation and consultation between the independent counsel and DOJ. Section 594(a)(10) of the Act authorizes the independent counsel to consult U.S. Attorneys for assistance. ${ }^{329}$ Most importantly, perhaps, $§ 594(\mathrm{~d})$ states that

323. See 28 U.S.C. § 594(a) (1994) (stating that the Attorney General retains control and discretion over those matters requiring her personal action under 18 U.S.C. $\$ 2516$ ).

324. See Barrett, supra note 318, at 531-35. Barrett argues that DOJ has not ceased to give legal advice and even legal representation to executive branch departments and personnel when independent counsels have been appointed to investigate persons alleged to have committed criminal misconduct. See id. at 532-33. These actions, however, on their face appear to be neither investigative nor prosecutorial and therefore not inconsistent with the directives of the Act. See id. at 534.

325. See id. at 538-41. Barrett points out that although the Act directs DOJ to provide whatever personnel and assistance an independent counsel may request, no independent counsel has sought to exercise this power in the form of requesting that the Solicitor General actually argue or support the independent counsel's position. See id. at 538. Independent counsels, however, have asked for litigation assistance from the Solicitor General, but Attorneys General have not always granted these requests. See id. Barrett maintains that the Act, by authorizing the Attorney General and the Solicitor General to file amicus briefs, may undercut the independent counsel's litigation prospects and his or her broader credibility with the courts and the public. See id. at 539-40.

326. See infra Part IV.C. 4 (discussing the operation of the independent counsel Act in connection with the Classified Information Procedures Act).

327. See 28 U.S.C. $\$ 597(a)$ (1994). The purpose of $\S 597$ (a) is to prevent investigation by DOJ that would duplicate and possibly impede the work of the independent counsel. See United States v. Briscoe, 798 F. Supp. 28, 33 (D.D.C. 1992) (citing In re Sealed Case, 829 F.2d 50, 56 (D.C. Cir. 1987)).

328. See 28 U.S.C. \& 597(a) (1994). The Act does not address, however, whether DOJ may continue to exercise its traditional, noninvestigative and nonprosecutorial functions proximate to an independent counsel investigation, such as providing legal advice and representation to components and employees of the executive branch.

329. See id. \$ 594(a)(10). "This recommendation will further ensure that public officials are afforded the same application of law as would be a private citizen, whenever this is possible." S. REP. No. 97-496, at 17 (1982), reprinted in 1982 U.S.C.C.A.N. 3537, 3553. 
an independent counsel may request assistance from DOJ necessary to carry out his or her mandate and that DOJ shall provide such assistance. ${ }^{330}$

In passing the Act, Congress recognized that "there will have to be a certain amount of coordination and cooperation between a special prosecutor and the Department of Justice so that the lines of jurisdiction between the Department and the special prosecutor are clear and adequately encompass any peripheral matters related to the special prosecutor's jurisdiction." 331

One area of cooperation that the courts have found acceptable is joint prosecutions. ${ }^{332}$ One such instance of cooperation and assistance between the independent counsel and DOJ occurred during Independent Counsel Walsh's investigation of Iran-Contra. Walsh empanelled a grand jury under his authority under $\$ 594(\mathrm{a})(1)$, but Lt. Col. Oliver North, subpoenaed to testify before the grand jury, then filed a complaint claiming that the independent counsel provisions of the Act are unconstitutional and sought to enjoin the grand jury proceedings. $^{333}$ In response to this constitutional challenge, the Attorney General promulgated a regulation that established the "Office of the Independent Counsel: Iran/Contra," appointed Walsh to that office, and delegated to that office the authority identical to that provided to an independent counsel under the Act and jurisdiction identical to that outlined by the Special Division. ${ }^{334}$ North claimed that the creation of the office violated the Appointments Clause of the Constitution, but the court disagreed and held that the Attorney General

330. See 28 U.S.C. $\$ 594(d)(1)$ (1994). The Act states that the type of assistance includes access to records or other materials and the use of resources and personnel. See id.

This provision enables independent counsels to use, for example the laboratory resources and investigative agents of the FBI as well as other physical resources in the Justice Department. It also enables them, standing in the shoes of the Attorney General, to request assistance from other investigative agencies such as the Internal Revenue Service, Secret Service, Inspectors General and Customs Service, which routinely assist the Department of Justice with its criminal investigations.

S. REP. No. 100-123, at 22-23 (1987), reprinted in 1987 U.S.C.C.A.N. 2150, 2171-72. Apparently, in several instances during the Reagan Administration, DOJ and other agencies requested reimbursement from the independent counsel for the provision of these services. See id. at 23, reprinted in 1987 U.S.C.C.A.N. at 2172 . This is bizarre, because costs incurred by the Office of the Independent Counsel come out of DOJ's budget, see 28 U.S.C. $\$ 594(d)(2)(1994)$; the purpose of the requests apparently was to distort the record of expenses of the independent counsel's investigation.

In enacting $\$ 594(d)$, Congress stated:

While being dependent on the Department of Justice for resources and personnel could potentially influence the independence of a special prosecutor, the Committee feels that the experience in the recent past of the Department of Justice providing adequate resources for the Watergate Special Prosecution Force, and the fact that a special prosecutor can at any time inform the Congress of any problems he is having getting adequate resources from the Department of Justice, will ensure that a special prosecutor will get the resources and personnel he needs to perform his duties.

S. REP. NO. 95-170, at 68 (1977), reprinted in 1978 U.S.C.C.A.N. 4216, 4284.

331. Id. at 76, reprinted in 1978 U.S.C.C.A.N. at 4292.

332. See Briscoe, 798 F. Supp. at 34. In Briscoe, the independent counsel and the U.S. Attorney for the District of Columbia sought the consolidation of United States v. Briscoe, Wilson, and Steier, a criminal case initiated by the independent counsel and United States v. Briscoe and Steier, brought by the United States Attorney for the Southern District of Florida. See id. at 30.

333. See In re Sealed Case, 829 F.2d 50, 52 (D.C. Cir. 1987).

334. See id. 
possessed both constitutional and statutory authority to create the Office of the Independent Counsel: Iran/Contra. ${ }^{335}$

In United States $v$. Briscoe, ${ }^{336}$ the defendants argued that consolidation of indictments issued by an independent counsel and a U.S. Attorney would violate the purpose and terms of the Act because it would undermine the independence of the independent counsel. ${ }^{337}$ In rejecting this argument, the court held that cooperation at the initiative of the independent counsel does not violate the purpose of the Act, which is to prevent interference by DOJ. ${ }^{338}$ Defendants further contended that consolidation violated $\S 597(\mathrm{a})$ of the Act, which requires DOJ to suspend any investigation into a matter within an independent counsel's mandate. $^{339}$ The court held that a joint prosecution of both indictments is comparable to the parallel appointment that was at issue in the IranContra investigation in that it required the independent counsel and DOJ to cooperate, but would not subject the independent counsel to the supervision or control of DOJ. ${ }^{340}$

3. The Independent Counsel's Compliance with Written or Other Established Policies of DOJ to the Extent the Policies Are Not Inconsistent with the Act. Although the independent counsel conducts his or her investigation outside DOJ, there nevertheless remains a relationship between his or her activities and DOJ policies: ${ }^{341}$ The Act states that an independent counsel must comply with "the written or other established policies" of DOJ "except to the extent that to do so would be inconsistent ${ }^{[342]}$ with the purposes of [the Act].",343

335. See id. at 59. The court also held that the tenure provision of the Act-that the independent counsel was removable for "good cause, physical disability, mental incapacity, or any other condition that substantially impairs the performance" of his or her duties-was not ripe for review. See id. at 6062. The court noted that the Attorney General's regulation gave Walsh a parallel source of authority for his grand jury investigation and thus North could not claim to suffer harm from the removal provisions of the Act unless there was a certain action Walsh would not undertake if he relied solely upon the regulation for his source of power. See id. at 61.

336. 798 F. Supp. 28 (D.D.C. 1992).

337. See id. at 33 .

338. See id. The court also held, in a footnote, that the defendants had standing under the Act to object to a violation of the autonomy of the independent counsel. See id. at $33 \mathrm{n} .13$ (citing Sealed Case, 829 F.2d at 55-56 (reaching the merits of an objection similar to that of the defendants, albeit without specifically addressing the standing issue)).

339. See id. at 33.

340. See id. at 34.

341. For recent commentary on the relationship between the independent counsel and DOJ policies and procedures, see generally Barrett, supra note 318, at 527-28; Godes \& Howard, supra note 253, at 885-86. See also HARRIGER, supra note 5, at 141-46 (discussing relationship with DOJ generally).

342. The 1982 amendments provided that the special prosecutor would be required to follow DOJ policies "except where not possible"; under the law enacted in 1978, the independent counsel had to follow DOJ policies "to the extent the special prosecutor deems appropriate." S. REP. No. 97-496, at 16 (1982), reprinted in 1982 U.S.C.C.A.N. 3537, 3552; see also Katy J. Harriger, The History of the Independent Counsel Provisions: How the Past Informs the Current Debate, 49 MERCER L. REV. 489, 508 (1998) (outlining the history and substance of the 1982 amendments to the Act). "The intent of this change is to create a presumption that the special prosecutor will follow prosecutorial guidelines unless extenuating circumstances exist." S. REP. NO. 97-496, at 16 (1982), reprinted in 1982 U.S.C.C.A.N. at 3552. "If he does deviate from established practices of the Department, the special prosecutor should 
Because knowledge of DOJ policies is a prerequisite for compliance with them, the statute directs the independent counsel to consult with DOJ regarding its criminal law enforcement policies. ${ }^{344}$ Furthermore, an independent counsel must consult and comply with DOJ's procedures and policies regarding the handling and use of classified information ${ }^{345}$ and expenses.

For example, Congress stated in the 1987 reenactment of the Act that, in issuing subpoenas, an independent counsel "stands in the place of the Attorney General and should follow relevant Department of Justice policies and practices. ${ }^{347}$ In 1996, Independent Counsel Kenneth Starr issued a grand jury subpoena for the full transcript and videotape of an interview given by Susan McDougal to ABC journalist Diane Sawyer. ${ }^{348} \mathrm{ABC}$ moved to quash the subpoena on the ground, inter alia, that the Independent Counsel did not follow DOJ guidelines regarding the issuance of subpoenas to the media (which re-

thoroughly explain his reasons for doing so in his report to the court at the conclusion of his investigation." Id.

The 1994 reenactment of the Act changed the language from "except where not possible" to "except where inconsistent with the purposes" of the Act. The Senate Report noted that "[t]he Committee intends independent counsels to follow established Justice Department policies on criminal law enforcement to the maximum extent possible to ensure that persons subjected to an independent counsel investigation are not subjected to a more rigorous application of the criminal law than other citizens." S. REP. NO. 103-101, at 32 (1993), reprinted in 1994 U.S.C.C.A.N. 748, 777.

343. 28 U.S.C. $§ 594(f)(1)(1994)$. "By obligating independent counsels to comply with the Department's policies on law enforcement, however, the policies are not intended to be transformed into mandatory directives; they are intended to retain their character as important guidelines which should be followed unless an unexpected situation or other good reason justifies making an exception." S. REP. NO. 100-123, at 24 (1987), reprinted in 1987 U.S.C.C.A.N. 2150, 2173. "[T] he provision is not intended to provide the Department of Justice with a legal basis for assuming control over the prosecution strategy of independent counsels in order to enforce compliance with the Department's policies." Id. at 24-25, reprinted in 1987 U.S.C.C.A.N. at 2173-74. Thus, although it might not violate the letter of the law, DOJ's attempt to manipulate the independent counsel by enacting rules specifically designed to control the particular investigation would certainly violate the Act's spirit. The independent counsel's remedy would be noncompliance with the questionable rule; the Attorney General could respond only by exercising the power of removal.

Furthermore, Congress stated in enacting the Act that "[t]his section should be interpreted more as a goal than as a command." S. REP. NO. 95-170, at 69 (1977), reprinted in 1978 U.S.C.C.A.N. 4216, 4285. "Rather than to provide procedures whereby the special prosecutor could get the permission from the Attorney General or the court not to follow such Departmental policies, it was the decision of the Committee that the best procedure was to leave the decision of when such written policies of the Department of Justice are to be followed in the discretion of the special prosecutor." Id. "The special prosecutor's decision as to whether it is practicable to comply with the written policies ... should include such factors as his perception of the fundamental fairness and justice, his perception of what is required to conscientiously conduct the investigation and prosecution assigned to him ... and other relevant factors." Id.

The question whether an independent counsel who is charged with investigating the President violates the Act by declining to follow the DOJ policy against indicting a sitting President has never been decided nor (at the time of this writing) has it arisen. See Symposium, supra note 103, at 1597.

344. See 28 U.S.C. \& 594(f)(1) (1994).

345. See id. $\$ 594(\mathrm{f})(2)$. This is discussed more fully infra Part IV.C.4.

346. See 28 U.S.C. $\$ 594(l)(1)(C)(1994)$.

347. S. REP. NO. 100-123, at 22 (1987), reprinted in 1987 U.S.C.C.A.N. $2150,2171$.

348. See In re Grand Jury Subpoena Am. Broadcasting Cos., 947 F. Supp. 1314, 1316-17 (E.D. Ark. 1996). 
quire the approval of the Attorney General for all subpoenas to the media). ${ }^{349}$ The court held that the plain language of $\$ 594(\mathrm{f})$ made it clear that, while the Independent Counsel must comply with DOJ guidelines, he is not bound to follow them where doing so would be inconsistent with the purpose of the Act-as would be the case by requiring an independent counsel to seek the Attorney General's approval. ${ }^{350}$

On the other hand, an independent counsel's actions would be inconsistent with the Act's purposes where the independent counsel refuses to obey a clearly established DOJ policy not to prosecute for the stated offense or on the asserted legal theory. Congress clearly expressed its intent that in these circumstances-as in the Jordan and Kraft cocaine cases ${ }^{351}$ - the Act should not be invoked to trigger the appointment of an independent counsel. ${ }^{352}$

\section{The Classified Information Procedures Act. The Classified Information} Procedures Act ("CIPA")" makes the Attorney General responsible for deciding whether classified information will be declassified for use at a criminal trial. $^{354}$ CIPA was enacted in 1980 to prevent criminal defendants from

349. See id. at 1317. The DOJ guidelines at issue stated that "no subpoena may be issued to a member of the news media ... without the express authorization of the Attorney General." Id. at 1321 (quoting 28 C.F.R. $\$ 50.10(\mathrm{e})$ ).

350. See id. at 1321-22. The court cited the legislative history of the Act in holding that to require the independent counsel to obtain the express authorization of the Attorney General for the issuance of the subpoena would be contrary to the purpose of the Act:

$[T]$ he committee does not intend that independent counsels comply with Department policies which would undermine their independence or hinder their mission. For example, where a

Department policy requires the Attorney General's approval of a particular prosecution

strategy, an independent counsel may waive compliance as inconsistent with the statute's goal

of creating an "independent" office.

Id. at 1322 n.9 (quoting S. REP. NO. 103-101, at 32 (1993), reprinted in 1994 U.S.C.C.A.N. 748, 777).

351. See supra notes $197-200$ and accompanying text.

352. See David Johnston, Reno Ends Inquiry into Fund-Raising by Vice President, N.Y. TIMES, Nov. 25, 1998, at A1. Attorney General Reno concluded at the end of her preliminary investigation of allegations of criminal wrongdoing by Vice President $\mathrm{Al}$ Gore in fund-raising for the 1996 campaign that the evidence was too weak to support a prosecution of Gore for lying. She stated that there is " only weak circumstantial evidence of the Vice President's knowledge-his presence at a meeting where the subject was briefly discussed-which I do not believe provides reasonable grounds to believe that further investigation of this matter is warranted." Id. (quoting Report from Attorney General Reno to Special Division).

353. 18 U.S.C. app. III $\$ \S 1-16$ (1994). CIPA contains three basic provisions: (1) pretrial notice by the defendant that he or she intends to use classified information; (2) control of the admissibility of the classified information, including in camera proceedings; and (3) interlocutory appeal by the government of adverse rulings. See Sandra D. Jordan, Classified Information and Conflicts in Independent Counsel Prosecutions: Balancing the Scales of Justice After Iran-Contra, 91 COLUM. L. REV. 1651, 1658 (1991); see also Ronald K. Noble, The Independent Counsel Versus the Attorney General in a Classified Information Procedures Act-Independent Counsel Statute Case, 33 B.C. L. REV. 539, $550-56$ (1992) (describing CIPA's statutory provisions). To resolve the conflict between CIPA and the Act, Noble argues for the creation of an Office of Independent Special Arbiter for classified information that would issue advisory opinions on whether the release of the classified information would threaten national security. See Noble, supra, at 544.

354. See, e.g., United States v. Smith, 780 F.2d 1102, 1105 (4th Cir. 1985) (stating that Congress enacted CIPA to confront the problem of a criminal defendant who "threatens to reveal classified information during the course of his trial in the hope of forcing the government to drop the criminal charge against him"). 
escaping prosecution by threatening to disclose classified information. CIPA permits the trial judge to rule on questions of admissibility before the introduction of the evidence in open court. ${ }^{355}$ Neither CIPA nor the Act makes a reference to the other ${ }^{356}$ and the Act provides no mechanism to challenge classification decisions made by executive branch members. The interaction between the Act and CIPA provides yet another opportunity for a complex and conflicting relationship to develop between the independent counsel and DOJ and the Attorney General.

Although the Act does not address CIPA explicitly, it does seem, implicitly, to reallocate the Attorney General's traditional powers over classified information by providing that independent counsels are entitled to receive "appropriate national security clearances" in obtaining any testimony and reviewing any documents. ${ }^{357}$ Furthermore, the statute states that the independent counsel may go to court to enforce his or her legal rights to obtain information where someone attempts, by general withholding or by claiming a national security privilege, to keep the independent counsel from obtaining classified information. ${ }^{358}$ Finally, according to the Act, the independent counsel becomes the representative of the government and stands in DOJ's shoes for all prosecutions within its jurisdiction, the role of DOJ being limited to providing assistance, making amicus curiae presentations, and handling electronic surveillance. ${ }^{359}$ Arguably, in the absence of an express provision to the contrary, the Attorney General's powers under CIPA should transfer to the independent counsel upon the commencement of an independent counsel investigation. This is the issue that the Iran-Contra investigation grappled with but never resolved: Can an independent counsel exercise the powers of the Attorney General under CIPA?

355. See Jordan, supra note 353 , at $1652-53$. CIPA does not necessarily protect the defendant, but only the classified information. See id. at 1684 .

356. See United States v. Fernandez, 887 F.2d 465, 465 (4th Cir. 1989). Fernandez held that the Act grants the independent counsel sole authority to exercise the right to appeal, under $\S 7$ of CIPA, the trial court's rulings rejecting the substitution of versions of classified materials to be used at trial. See $i d$. at 465-66; see also Noble, supra note 353, at 561-63 (discussing Fernandez). Section 7(a) of CIPA authorizes the United States to take an interlocutory appeal from an adverse district court order concerning the disclosure of classified information. See 18 U.S.C. app. III § 7(a) (1994).

Fernandez was a former CIA service officer who was indicted on two counts of giving false statements in violation of 18 U.S.C. $\$ 1001$ and two counts of obstructing proceedings in violation of 18 U.S.C. $\$ 1505$ in connection with the Iran-Contra investigation. See Fernandez, 887 F.2d at 467.

357. 28 U.S.C. \& 594(a)(6) (1994).

358. See id. Justice Scalia noted this power of the independent counsel in his dissent in Morrison:

Another preeminently political decision is whether getting a conviction in a particular case is worth the disclosure of national security information that would be necessary. The Justice Department and our intelligence agencies are often in disagreement on this point, and the Justice Department does not always win. The present Act even goes so far as specifically to take the resolution of that dispute away from the President and give it to the independent counsel.

487 U.S. 654, 708 (1988) (Scalia, J., dissenting).

359. See 28 U.S.C. \& 594(a) (1994); see also supra Part IV.C.1 (discussing the roles of the independent counsel, DOJ, and the Attorney General). 
The Iran-Contra investigation was a minefield of classified information. In December 1986, the Attorney General applied to the Special Division seeking the appointment of an independent counsel with jurisdiction to investigate whether Lt. Col. Oliver North and others violated federal criminal law in the Iran-Contra affair. ${ }^{360}$ To prove the crimes alleged, Independent Counsel Walsh needed to use in open court classified information that otherwise might never have been made public. ${ }^{361}$ In ordinary criminal investigations and prosecutions that involve classified information, the Attorney General has the legal authority to balance law enforcement interests in making a particular criminal case against a more generalized concern for national security considerations. ${ }^{362} \mathrm{Al}-$ though the Act authorized Walsh to contest national security claims, it provided him with no explicit power to declassify this information so that his investigation could proceed.

Section 594(a) transfers all prosecutorial and investigative authority from the Attorney General to the independent counsel in "all" matters within his or her jurisdiction. ${ }^{363}$ In United States $v$. Fernandez, the Fourth Circuit noted that when an independent counsel is acting as prosecutor, the Attorney General need not balance the threat of public disclosure of classified information against the threat of ending the prosecution because the Act removes the possibility that the Attorney General's actions might end the prosecution. ${ }^{364}$ Where the independent counsel is bringing the prosecution, the Attorney General's only responsibility under CIPA is the protection of classified information. ${ }^{365}$ Although $\S 596(a)(6)$ concerns national security and classified information, the Fernandez court held that it was inapplicable to this case. ${ }^{366}$ The court held that the Attorney General did not resist a request for classified information, but rather attempted to exercise the independent counsel's prosecutorial authority. ${ }^{367}$

360. See In re Sealed Case, 829 F.2d 50, $51-52$ (D.C. Cir. 1987). The Special Division granted Independent Counsel Walsh jurisdiction beyond that requested by the Attorney General. See id. at 52 .

361. For a discussion of the relationship between independent counsel and DOJ regarding the use of classified information, see Barrett, supra note 318, at 535-37; Jordan, supra note 353. Jordan's article should be the starting point for researching the issues involving CIPA and classified information as it relates to the powers and function of the independent counsel. Jordan wrote prior to the expiration of the Act in 1992, and she advocated for congressional action to harmonize CIPA and the Act. See Jordan, supra note 353 , at 1654 .

362. Because DOJ has the power to conduct this balancing test even when the independent counsel is prosecuting a case, the role of the independent counsel's office with respect to classified information is very limited because the decisions regarding classification are made within DOJ and outside the control of the independent counsel. See id. at 1656.

363. 28 U.S.C. $\$$ 594(a) (1994).

364. 887 F.2d 465, 470 (4th Cir. 1989).

365. See id.

366. See id. at 471 n.6. The court stated that $\$ 596(a)(6)$ concerns the situation where the executive branch might seek to withhold from the independent counsel evidence that is relevant to the prosecution on grounds of national security. See id. The Act gives the independent counsel the power to apply for the required security clearances and to contest in court any claims of executive privilege. See 28 U.S.C. $\$ 594(\mathrm{a})(6)(1994)$.

367. See Fernandez, 887 F.2d at 471 n.6. 
In the prosecution of Oliver North, the Attorney General refused to declassify information that the independent counsel had informed him was necessary to the prosecution. ${ }^{368}$ Attorney General Thornburgh asserted ultimate control over the use of the classified information by filing affidavits based on the power he had under CIPA and ordered that specified items of classified information not be used at trial. When the information necessary to conduct the trial was not declassified, Walsh was left with no options, and the court dismissed the counts against North. ${ }^{369}$ Independent Counsel Walsh never argued that the power of the Attorney General under CIPA to declassify information had been transferred to him. ${ }^{370}$

The issue raised by Iran-Contra was whether any high-level official ever could be prosecuted successfully when national security issues are intimately tied up with alleged criminal conduct. ${ }^{371}$ CIPA involves the duties and respon-

368. See William Michael Treanor, Independent Counsel and Vigorous Investigation and Prosecution, 61 LAW \& CONTEMP. PROBS. 149, 157-58 (Winter 1998) (describing power of the executive branch to control effectively the investigation of an independent counsel by refusing to declassify information required by the independent counsel). The charges against North were conspiracy to defraud the United States by providing covert support for the Contras and that the Iran-Contra diversion was a theft of government funds. See id. at 158.

369. In the Oliver North trial, the two lead counts of the indictment were dismissed. See LAwrence E. Walsh, Firewall: THE Iran-CONTRA CONSPIRACY AND COVER-UP 180 (1997). In the case of CIA officer Joseph Fernandez, the court dismissed the entire indictment. See United States v. Fernandez, 913 F.2d 148, 149 (4th Cir. 1990).

Walsh has recently stated that

I never asked Congress to consider giving [the classified information power] to an independent counsel because I did not think a transient should be making decisions about national security where he has no deep background in that area. And it seems to me that there are areas where the interpretation of the law should be in the hands of those who are permanently stewards of it, rather than in a transient.

Symposium, A Roundtable Discussion on the Independent Counsel Statute, 49 MERCER L. REV. 453, 483 (1998).

However, there are significant problems with vesting this decisionmaking power in the Attorney General, DOJ, or indeed, with any official or department that is part of the executive branch. If the goal of the Act is independence from these executive branch actors, placing in their hands such decisionmaking power which fundamentally impacts the outcome of an investigation or prosecution can subvert this goal.

370. See Treanor, supra note 368 , at 160 . Treanor suspects that, had Walsh maintained that he had the power to declassify information under CIPA, Walsh would have lost because a court would have been unlikely to find that the power of classification-one attaching to the executive branch-would have passed to the independent counsel under the Act. See id. Since the independent counsel's position is to investigate federal crimes and prosecute the guilty, the independent counsel would be an inappropriate person to balance the competing interests of national security and law enforcement. See id.

371. See id. at 1672. It should be noted, however, that simply giving the independent counsel the power under CIPA to exercise all of the power of the Attorney General would implicate the constitutionality of the Act. The Supreme Court's decision in Morrison v. Olson, upholding the constitutionality of the Act, was predicated on the finding of the Court that the independent counsel was an inferior executive officer. See 487 U.S. 654, 691 (1988) (stating that "the independent counsel is an inferior officer under the Appointments Clause, with limited jurisdiction and tenure and lacking policymaking or significant administrative authority"). Whether the Court would reach the same determination where an independent counsel was charged with a policymaking role involving the declassification of sensitive national security information is questionable. A total transfer to the independent counsel of the power to declassify national security information would likely raise significant separation of powers concerns. 
sibilities of the "United States," so it is unclear which entity-the Attorney General or the independent counsel-fulfills that role where an independent counsel has been appointed. ${ }^{372}$ Ultimately, the question is still an open one. Because of the unique nature and purpose of the Act-a mechanism that provides for the investigation and prosecution of high-level governmental officials-undoubtedly a future independent counsel or special prosecutor will face the problem of using classified information at trial.

5. Removal of the Independent Counsel. The Act provides that the independent counsel "may be removed from office, other than by impeachment and conviction, only by the personal action of the Attorney General and only for good cause, physical or mental disability ... , or any other condition that substantially impairs the performance of such independent counsel's duties. ${ }^{, 373}$ Any such removal by the Attorney General must be accompanied by a report to the Special Division and Congress explaining the action. ${ }^{374}$ Finally, the independent counsel may demand judicial review of the removal of the independent counsel by the Attorney General. ${ }^{375}$ The Supreme Court has upheld this judicial review provision:

[A]s with the provision of the Act conferring the appointment authority of the independent counsel on the special court, the congressional determination to limit the removal power of the Attorney General was essential, in the view of Congress, to establish the necessary independence of the office. We do not think that this limitation as it presently stands sufficiently deprives the President of control over the independent counsel to interfere impermissibly with his constitutional obligation to ensure the faithful execution of the laws. ${ }^{376}$

372. See Jordan, supra note 353 , at 1666.

373. 28 U.S.C. \& 596(a)(1) (1994). The standard of removal was changed in 1982 from "extraordinary impropriety" to "good cause." It was felt that this change would enhance the constitutionality of the statute. See S. REP. NO. 97-496, at 17 (1982), reprinted in 1982 U.S.C.C.A.N. 3537, 3553.

The issue of "good cause" removal surfaced again in the 1987 reenactment of the statute. Congress was concerned with DOJ's position in the Reagan White House that a President could fire an independent counsel for good cause where the independent counsel refused to obey a presidential order to grant immunity to the target of the investigation. See S. REP. NO. 100-123, at 12 (1987), reprinted in 1987 U.S.C.C.A.N. 2150, 2161. "This interpretation of the statute completely misconstrues Congressional intent, which is to prevent the President's firing an independent counsel unless he or she engages in some type of misconduct ... [such as] "taking a bribe or committing an impropriety." Id. at 12-13, reprinted in 1987 U.S.C.C.A.N. at 2161-62 (quoting Lloyd Cutler, former counselor to President Carter).

374. See 28 U.S.C. § 596(a)(2) (1994).

375. See id. $\$ 596$ (a)(3). "[T]he division of the court is given the authority to review the removal of the special prosecutor to see if any of the statutory causes did exist. If such cause [sic] did not exist, and the removed special prosecutor so requests, the court may reinstate such a special prosecutor." $\mathrm{S}$. REP. NO. 95-170, at 73-74 (1977), reprinted in 1978 U.S.C.C.A.N. 4216, 4289-90.

We see no constitutional problem in the fact that the Act provides for judicial review of the removal decision [under $\S 596(\mathrm{a})(3)$ ]. The purpose of such review is to ensure that an independent counsel is removed only in accordance with the will of Congress as expressed in the Act. The possibility of judicial review does not inject the Judicial Branch into the removal decision, nor does it, by itself, put any additional burden on the President's exercise of executive authority.

Morrison, 487 U.S. at 693 n.33.

376. Morrison, 487 U.S. at $692-93$. 


\section{The Relationship Between the Independent Counsel and Congress}

Members of Congress can request that the Attorney General apply for the appointment of an independent counsel. ${ }^{377}$ Congress's role is otherwise limited to overseeing the activities of the independent counsel or the Attorney General under the Act, ${ }^{378}$ and to ordinary executive branch oversight, hearings, or the impeachment process.

1. Congressional Oversight. General oversight of the independent counsel is vested in congressional oversight committees. ${ }^{379}$ The Act requires the independent counsel to submit annual reports to Congress on his or her activities and requires the independent counsel to cooperate with congressional oversight jurisdiction. ${ }^{380}$ In renewing the Act in 1994, Congress added many of the congressional oversight provisions to make the independent counsel more accountable. ${ }^{381}$ These new provisions included rules on controlling the costs of

377. See 28 U.S.C. $\$ 592(\mathrm{~g})$ (1994); see also supra Part II.B.2.d (discussing the triggering of the Act by Members of Congress).

378. This oversight includes the receipt of reports and other information from the independent counsel and the conduct of audits of the independent counsel's expenditures. See 28 U.S.C. $\$ 595$ (b) (1994) (requiring the Attorney General to supply certain information to Congress about the receipt of information, the preliminary investigation, and whether the Attorney General determined, as the result of a preliminary investigation, that further investigation was not required); see also S. REP. No. $100-123$, at 29 (1987), reprinted in 1987 U.S.C.C.A.N. 2150, 2178 ("The purpose of these provisions is to enable congressional committees with oversight responsibilities to keep better track of actions taken by the Attorney General to implement the Act."). The Attorney General must also submit a report to the Judiciary Committees of Senate and House of Representatives justifying the removal of an independent counsel. See 28 U.S.C. \$ 596(a)(2) (1994). Congress has exclusive oversight of the Attorney General's compliance with the provisions of the Act. See Dellums v. Smith, 797 F.2d 817, 823 (9th Cir. 1986); cf. supra Part IV.A.1 (discussing the inability of private citizens to compel the Attorney General to conduct a preliminary investigation).

The involvement of Congress in oversight of the independent counsel is perfectly constitutional: These are "functions that we have recognized generally as being incidental to the legislative function of Congress"; therefore the congressional role outlined by the Act does not infringe upon the separation of powers. Morrison, 487 U.S. at 694.

379. See 28 U.S.C. § 595(a)(1) (1994). Oversight is currently vested with the House of Representatives Committee on the Judiciary and the Senate Committee on Governmental Affairs. One commentator has argued that Congress has refused to use the power of the purse to control the conduct of independent counsel investigations. See O'Sullivan, supra note 260, at 496. Although the usage of resources must be reported to Congress by the independent counsel under the Act, there is no explicit constraint placed on spending by the independent counsel, nor is the independent counsel barred from earning outside income, a bar which, if in place, might militate against the independent counsel dragging out an investigation past the point of fruitfulness. See infra Part IV.D.2 (discussing the auditing provisions of the Act).

380. See 28 U.S.C. § 595(a) (1994).

381. See, e.g., id. \$ 594(l) (imposing cost controls); id. § 594(f) (clarifying the responsibility of independent counsels to comply with DOJ policies); $i d$. \& 594(h)(3) (increasing public access to independent counsel reports); see also S. REP. NO. 103-101, at 27-30, 32-34 (1993), reprinted in 1994 U.S.C.C.A.N. 748, 771-75, $777-79$ (discussing the intent and purpose of the amendments that increase the accountability of the independent counsel); Harriger, supra note 342, at 513-14 (discussing the history and substance of the 1994 amendments to the $\mathrm{Act}$ ). For an argument that the congressional oversight and reporting provisions are weak control mechanisms on the independent counsel, see James P. Fleissner, The Future of the Independent Counsel Statute: Confronting the Dilemma of Allocating the Power of Prosecutorial Discretion, 49 MERCER L. REV. 427, 435 (1998). 
investigations, ${ }^{382}$ audits of independent counsel expense records, ${ }^{383}$ annual reports from the independent counsel to Congress, ${ }^{364}$ compliance with DOJ policies and procedures regarding the handling of classified documents, ${ }^{385}$ and a periodic review by the appointing court to determine whether the investigation should be continued or terminated. ${ }^{386}$

The sunset provision directing that the Act lapse five years from its effective date is another mechanism for congressional oversight. This provision was designed to ensure that Congress took affirmative legislative action informed by debate to assess the function and further the effectiveness of the Act. ${ }^{387}$

Perhaps the most contentious oversight mechanism, however, is the independent counsel's final report filed with Congress at the conclusion of each investigation. ${ }^{388}$ Although the Act places no limit on the duration of the independent counsel, upon termination of his or her office, the independent counsel must file a report with the Special Division "setting forth fully and completely a description of the work of the independent counsel, including the disposition of all cases brought." ${ }^{389}$

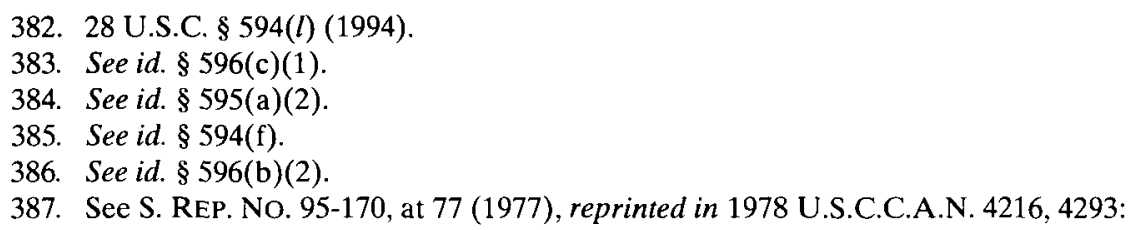

Five years is a reasonable period to permit the provisions of [the Act] to operate and then to review those provisions to see if too many or too few special prosecutors have been appointed, to determine whether there is a need for a revision of the standards defining when a conflict of interest exists, or to determine if there is a need to revise the method of appointment, the method of removal, or any other significant portion of this chapter.

388. Some commentators have argued that the Act's broad reporting requirements have fueled partisan political fires. See, e.g., Soloway, supra note 277, at 638. Soloway argues that, even though the 1994 amendments to the Act removed the requirement that the independent counsel state his or her reasons for not prosecuting a case, the independent counsel can still place his or her conclusions in the public forum, thus affecting the political atmosphere. See id. Likely, though, no amount of amendment to the Act can control the personal and professional judgment of how a prosecutor-whether he or she is an independent counsel-interacts with the media and the public. See also Symposium, supra note 103, at 1558 (statement of Larry Thompson) ("I think that perhaps the filing of this report and the writing of the report actually serve to not only make the investigation go longer, but perhaps serve to overly politicize the investigation."); see id. at 1560 (statement of Robert Fiske, Jr.) ("[T]here is an interrelationship ... between a report requirement and the complaints from so many parts of the media and the public about the length and expense of the investigation."). But see id. at 1558 (statement of Judge Lawrence Walsh) ("Although there is congressional oversight of the independent counsel, it is very difficult to make that effective, and I think that to make congressional oversight effective, they need a report."). There are, perhaps, a number of ways that the final report could be improved upon. See, e.g., id. at 1556 (statement of Jacob Stein) ("[I]f a report should be written-and there are many good reasons there shouldn't be a report-perhaps it should be confined to who you employed, what their backgrounds were to show that you had quality people, and some indication why the investigation took the time it did.").

389. 28 U.S.C. $\$ 594($ h)(1)(B) (1994). Not only does an independent counsel operate with an unlimited time frame, but also with an unlimited budget. The Act provides that DOJ must pay for "all costs relating to the establishment and operation" of an independent counsel investigation and prosecution. Id. $\$ 594(\mathrm{~d})(2)$.

The final report requirement of the Act is a key means of ensuring the accountability of the independent counsel. At least so says Congress. See, e.g., S. REP. No. 95-170, at 70 (1977), reprinted in 1978 U.S.C.C.A.N. 4216, 4286 ("This mandatory final report is considered by the Committee to be 
The center of the controversy over final reports was Independent Counsel Walsh's final report in the Iran-Contra investigation. At the time Walsh submitted his report, the Act required the independent counsel to explain "the reasons for not prosecuting any matter within the prosecutorial jurisdiction of such independent counsel which was not prosecuted." ${ }^{390}$ The release of Walsh's report to the public was contested, and the Special Division allowed for the release of the report, noting that the Independent Counsel's argument for its release hinged on the legislative mandate. ${ }^{391}$ The court nevertheless found the report to be "rife with accusations of guilt of criminal conduct against persons never indicted or convicted.... Unfortunately for movants, and perhaps for the tradition of fairness, the statute ... require[s] that the Independent Counsel file a report., ${ }^{392}$

As a result of Walsh's report, the 1994 reauthorization of the Act deleted the requirement that the independent counsel include in the final report the "reasons for not prosecuting any matter within the prosecutorial jurisdiction of such independent counsel.", ${ }^{393}$ "By eliminating the requirement to explain every decision not to indict, the [Act] does not prohibit such explanations, but instead gives each independent counsel the discretion to provide such an explanation when he or she determines it would be in the public interest." ${ }^{394}$ One

very important to ensure the accountability of a special prosecutor."); $i d$. ("This final report will provide a detailed document to permit the evaluation of the performance of a special prosecutor at an appropriate time."); $i d$. ("This report must be in sufficient detail to allow a determination of whether the special prosecutor's investigation was thoroughly and fairly completed."); S. REP. NO. 103-101, at 33 (1993), reprinted in 1994 U.S.C.C.A.N. 748, 778 ("These periodic reporting requirements will provide Congress with regular information to assist in its oversight responsibilities."). However, because such an accounting would be made after the fact, it is of questionable use in controlling the ongoing abuses of the independent counsel.

390. 28 U.S.C. $\S 595(b)(2)(1982)$.

391. See In re North, 16 F.3d 1234, 1238 (D.C. Cir. 1994). In releasing the report, the court was guided by the standards set forth in a 1987 Senate Report: (1) whether the subjects of the investigation have already been disclosed to the public; (2) whether the subjects did not object to the filings being released to the public; (3) whether the filings contain information that is already publicly known; and (4) whether the filings consist of legal or factual rulings in a case that should be publicly available to understand the court's rules and precedents or to follow developments in a particular manner. See id. at 1240 (quoting S. REP. NO. 100-123 (1987), reprinted in 1987 U.S.C.C.A.N. 2150).

As far as the third factor noted above is concerned, the court commented:

[S]ome might suggest that a future Independent Counsel wishing to ensure the release of his report would go on television and make comments accusing the subjects of his report of crimes so that the Court could later find that the contents of the report were already public. As this Court has no supervisory power, there would be little we could do about it. As the Independent Counsel is virtually without supervision, there would be little anyone could do about it. This danger may be inherent in the nature of the Independent Counsel.

Id. at 1241 .

392. Id. at 1238 .

393. In explaining the decision to eliminate this requirement, Congress reported:

Other federal prosecutors do not normally provide public explanations of decisions not to indict and, in deviating from this norm, independent counsels must exercise restraint. The power to damage reputations in the final report is significant[;] ... the final report requirement is not intended in any way to authorize independent counsels to make public findings or conclusions that violate normal standards of due process, privacy or simple fairness.

H.R. CONF. REP. NO. 103-511, at 19 (1994), reprinted in 1994 U.S.C.C.A.N. 792, 802.

394. 140 Cong. Rec. S6,374 (daily ed. May 25, 1994) (remarks of Sen. Levin). 
Senator has stated that, in explaining a decision not to indict, the independent counsel should consider "whether the individual was central to the independent counsel's jurisdictional mandate, whether the explanation would exonerate an innocent individual, and whether an explanation would violate normal standards of due process, privacy or simply fairness.",395

Finally, the Act states that "[t]he division of the court shall make such orders as are appropriate to protect the rights of any individual named in such [final] reports.", 396 "In determining what statements, reports or information to make public, the special prosecutor will, of course, be bound by the canons of ethics of the legal profession and the basic principles of our criminal justice system.",397 "In considering whether to release court filings, it is intended that the court balance the right of the subjects of investigations to be shielded from publicity about unfounded or unfair allegations with the right of the public to inquire about prosecutions under [the] Act." ${ }^{398}$

2. Auditing. The Act requires that the independent counsel "conduct all activities with due regard to expense." ${ }^{399}$ By allowing this discretionary standard, although Congress provided the independent counsel with the broad flexibility and independence to investigate and prosecute, it required the independent counsel to submit an annual report on his or her activities, including the financial expenditures. Congress intended that a balance exist between controlling costs and safeguarding the integrity of our government. Congress reasoned that " $t]$ he audit provision will provide needed accountability for the funds actually spent by independent counsels and will

395. Id. (remarks of Sen. Levin). Senator Levin stated that the Conference Report further cautioned against "conclusory statements that an individual is guilty of criminal misconduct ...." Id.

396. 28 U.S.C. $\$ 594(\mathrm{~h})(2)(1994)$. This authority of the Special Division provides a check against what would otherwise be the unbridled discretion of the independent counsel in filing the final report. See In re Sealed Motion, 880 F.2d 1367, 1370 (1989) (per curiam). The court in Sealed Motion held that because the right to secrecy in a grand jury proceeding belongs to the witness, "a grand jury witness named in an independent counsel's report is entitled to a transcript of his own testimony absent a clear showing by the government that other interests outweigh the witness' right to such transcript." Id. at 1370-71. In reaching this holding, the court relied on Morrison, which compared the Special Division's functions under the Act to functions that federal judges undertake in other contexts, such as deciding whether to allow the disclosure of matters occurring before a grand jury. See id. at 1374 (citing Morrison v. Olson, 487 U.S. 654, 681 (1988)).

In another $\$ 594(\mathrm{~h})(2)$ case, the Special Division granted the emergency motion of the Society of Professional Journalists and others to unseal all sealed motions and papers pertaining to the release of Independent Counsel Walsh's final report, holding that the disclosure was in the public interest. See In re North, 21 F.3d 434, 434-35 (D.C. Cir. 1994) (per curiam).

397. S. REP. NO. 95-170, at 70 (1977), reprinted in 1978 U.S.C.C.A.N. 4216. 4286.

398. S. REP. NO. 100-123, at 21 (1987), reprinted in 1987 U.S.C.C.A.N. $2150,2170$.

399. 28 U.S.C. $\$ 594(l)(1)($ A)(i) (1994).

Exercising "due regard for expense" means that an independent counsel must not conduct an investigation or prosecution on the premise that "price is no object" or that costs are irrelevant when making decisions in the case. Independent counsels, like all other federal employees, must take care that federal funds are spent wisely and without extravagance or waste.

S. REP. NO. 100-123, at 28 (1987), reprinted in 1987 U.S.C.C.A.N. 2150, 2177. "In deciding whether to incur a particular expense and, if so, how much to pay for the underlying item, independent counsels should be guided by the rules and practices of other federal agencies." Id. 
deter the authorization of inappropriate or excessive expenditures. It will also provide accurate information as to whether additional fiscal controls are needed for independent counsel proceedings." "400 Furthermore, throughout the course of the investigation, the independent counsel is required to submit reports every six months to the Special Division identifying and explaining all expenses related to the investigation. ${ }^{401}$ The Special Division, at its discretion, may disclose the contents of these reports to Congress or the public. ${ }^{402}$ Although it is recognized that certain information will need to be kept confidential, the Act states that "information adequate to justify the expenditures that the office of independent counsel has made" should be provided in the expense report. ${ }^{403}$

3. Parallel Congressional Investigations. The Act has failed to address a fundamental problem brought to light by the Iran-Contra scandal: What happens to the independent counsel's role if Congress initiates a simultaneous inquiry regarding the same subject as the independent counsel investigation? ${ }^{404}$ Even though Independent Counsel Walsh warned Congress that his investigation could be tainted if key figures in the investigation were given immunity and were compelled to testify, Congress conferred immunity on Oliver North, who freely testified regarding obstruction of justice and other crimes he committed in connection with Iran-Contra. ${ }^{405}$

400. H.R. CONF. REP. NO. 100-452, at 38 (1987), reprinted in 1987 U.S.C.C.A.N. 2185, 2204.

401. See 28 U.S.C. $\S 594(h)(1)(1994)$. "The purpose of the status reports is to provide a general cost accounting and a mechanism for planning future expenditures." H.R. CONF. REP. NO. 100-452, at 33, reprinted in 1987 U.S.C.C.A.N. at 2199.

402. See 28 U.S.C. $\$ 594(\mathrm{~h})(2)$ (1994).

403. Id. $\S 595(\mathrm{a})(2)$.

404. Congress launched its own investigation of Iran-Contra in 1987. This section draws heavily on the analysis laid out in Peter W. Rodino, Jr., The Case for the Independent Counsel Statute, 19 SETON HALL LEGIS. J. 5, 19-21, 27-31 (1994). Professor Rodino was the Chairman of the House Judiciary Committee from 1973 to 1989.

Congress apparently avoided this problem in the Monica Lewinsky scandal. After the scandal broke in January 1998, House Judiciary Chairman Henry Hyde said, "It's in the bosom of the independent counsel. He has the resources, the personnel, the deposition authority, access to the grand jury, immunity power. Let him do his job. And then when he does that, we will do ours." Face the Nation (CBS television broadcast, Jan. 25, 1998). Whatever the reason for the congressional inaction, the perils of Iran-Contra have been avoided: Congress took no action in "Monicagate" until after Independent Counsel Starr delivered his report to Congress on September 9, 1998. See infra Part IV.D.4 (discussing the relationship between the independent counsel and the impeachment process).

During the Clinton Administration, there have been independent counsel investigations involving Secretary Cisneros, Secretary Brown, and Secretary Espy, but there have not been major parallel congressional investigations with respect to any of these investigations. See Symposium, supra note 103, at 1570 .

The issue was raised - and not resolved - in Watergate as well. More recently, Congress conducted hearings into Whitewater despite Independent Counsel Robert Fiske's warning that there might be interference with his charge if such hearings were precipitously held. See Rodino, supra, at 28.

405. See id. at 19. The courts subsequently ruled that Walsh's prosecutions were tainted by the compelled testimony; those who were most culpable in Iran-Contra were left unpunished. See United States v. Poindexter, 951 F.2d 369 (D.C. Cir. 1991); United States v. North, 920 F.2d 940 (D.C. Cir. 1990). 
A congressional investigation informs Congress how best to develop legislation, monitor the implementation of legislation and public policy, and disclose to the public how its government is functioning. ${ }^{406}$ It is a political reality that members of the opposite political party in Congress will want to hold a hearing whenever a potentially scandalous event occurs involving the President. ${ }^{407}$ Yet a congressional investigation that runs parallel to an independent counsel investigation presents a tension between Congress's need to oversee the activities of the government and the independent counsel's role of ferreting out and prosecuting criminal wrongdoing.

Congressman Henry Hyde described this tension in the context of the IranContra investigation:

Judge Walsh catches a lot of criticism because of the length of the investigation, but his problem was complicated by our investigation. I remember Judge Walsh coming up and pleading with us to defer this and defer that, but we were hell-bent-and I say "we"- the Democrats wanted to move into the public arena because they were going to nail Ronald Reagan and this was an opportunity too good to be missed.... They were willing to give immunity to anybody if it would lead to the top gun. ${ }^{408}$

However, attempting to control congressional parallel investigations through legislation may be a violation of the separation of powers, and very little else can be done about these conflicting goals other than letting the political system work out the tension: ${ }^{409}$

Under the law, Congress has the ultimate word, and it should be that way. Congress should make the decision as to whether it should grant immunity or not, and they are really the supreme governing agency in our government. And if they conclude that for political reasons-high-level political reasons-it is important to tell the public, the prosecutor should be subordinated. ${ }^{410}$

Even without giving anyone immunity, a parallel congressional investigation still can interfere with the investigation of an independent counsel by, for

406. See Symposium, supra note 103, at 1565 (statement of Judge Charles Haden II).

Congress performs a kind of watchdog function over the Executive Branch of our government. Congress holds hearings to explore issues of public policy about how we govern ourselves. Congress uncovers and exposes and publicizes misuse of government power, abuse of government power. Congress frequently targets particular individuals in the Executive Branch to expose misfeasance, with the result that those individuals resign or are, in some manner, run out of office....

Id. at 1568 (statement of John Nields, Jr.).

407. Rodino argues that Congress should remember its legislative purpose when setting up and conducting investigations that parallel investigations by independent counsels. See Rodino, supra note 404, at 28-29. Congressional oversight proceedings are intended to determine whether existing legislation is functioning correctly-Congress is not well equipped to conduct criminal investigations, which is the function of the independent counsel and the courts. See id. at 29. Rodino argues that Congress might legislate regarding the relationship between an independent counsel investigation and a parallel congressional inquiry. See $i d$. at 31 . Political realities probably cannot be changed through any alteration of the Act, however, and the attempt to do so might raise serious separation of powers problems.

408. Symposium, supra note 103 , at 1580.

409. See, e.g., Symposium, supra note 369, at 481 (statement of Judge Bell) ("I do not know that there is anything that you can do about that under our system."). Of course, the independent counsel always has the power to resign if he or she feels that the investigation is being significantly compromised by congressional action. See id. (statement of Mr. Cutler).

410. Symposium, supra note 103, at 1562 (statement of Judge Lawrence Walsh). 
example, locking a witness into a story under oath that later turns out not to be true. $^{411}$ At least for now, the Iran-Contra experience seems to have made it clear to Congress that it cannot expect to grant immunity to key witnesses and at the same time expect the independent counsel to conduct a successful investigation and prosecution. ${ }^{412}$

4. The Impeachment Process. The Act requires that an independent counsel advise the House of Representatives of any "substantial and credible" information that may constitute grounds for impeachment. ${ }^{413}$ This provision came into play for the first time in 1998 when Independent Counsel Kenneth Starr delivered his report to Congress detailing eleven possible grounds for the impeachment of President Clinton. ${ }^{414}$ Starr stated that "[i]t is not the role of this Office to determine whether the President's actions warrant impeachment by the House and removal by the Senate; those judgments are, of course, constitutionally entrusted to the legislative branch." from the mandate in the Act,

[ $t$ ] his Office is authorized ... to conduct criminal investigations and to seek criminal prosecutions for matters within its jurisdiction. . . . In carrying out its investigation, however, this Office also has a statutory duty to disclose to Congress information that "may constitute grounds for an impeachment," a task that inevitably requires judgment about the seriousness of the acts revealed by the evidence. ${ }^{416}$

Finally, Starr concluded,

[f]rom the outset, it was our strong desire to complete all phases of the investigation before deciding whether to submit to Congress information-if any-that may constitute grounds for an impeachment. But events and the statutory command of Section 595(c) have dictated otherwise. As the investigation into the President's actions with respect to Ms. Lewinsky and the Jones litigation progressed, it became apparent that there was a significant body of substantial and credible information that met the Section 595(c) threshold. As that phase of the investigation neared completion, it also became apparent that a delay of this Referral until the evidence from all phases of the investigation had been evaluated would be unwise. Although Section 595(c) does not specify when information must be submitted, its text strongly suggests that information of this type belongs in the hands of Congress as soon as the Independent Counsel determines that the information is reliable and substantially complete. ${ }^{417}$

411. See id. (statement of Robert Fiske, Jr.).

412. See, e.g., Symposium, supra note 369, at 481-82 (statement of Judge Lawrence Walsh) (stating that since Iran-Contra, Congress has not conducted parallel investigations with the same fervor and has been much more careful about granting immunity to witnesses).

413. 28 U.S.C. $\$ 595(c)$ (1994); see also Ruth Marcus, Impeachment Provision in Counsel Law Could Become Crucial, WASH. POST, Jan. 26, 1998 at A8 (discussing operation of $\S 595$ (c)). In 1974, Special Prosecutor Leon Jaworski followed a course similar to that chosen by Starr. The Watergate grand jury named President Nixon as an unindicted co-conspirator and referred its report to the House Judiciary Committee, which approved three articles of impeachment against Nixon shortly before his resignation. See id.

414. See STARR REPORT, supra note 21. See generally Julie R. O'Sullivan, The Interaction Between Impeachment and the Independent Counsel Statute, 86 GEO. L.J. 2193 (1998).

415. Id. at 27 (citing U.S. CONST. art. I, $\$ 2$, cl. 5; id. art. I, $\S 3$, cl. 6).

416. Id. (citation omitted).

417. Id. at 33 . 
Congress did, in fact, undertake impeachment proceedings against President Clinton. Clinton was impeached by the House of Representatives on December $19,1998,{ }^{418}$ but was acquitted by the Senate on February $12,1999 .{ }^{419}$ Critical to these proceedings was the evidence compiled and report submitted by Starr. Undoubtedly, the relationship between Starr and Congress in the Clinton impeachment proceedings will color the future of the Act and the operation of future special prosecutors.

A further ramification of the impeachment proceedings against Clinton and Starr's involvement in them is the possible investigation of an independent counsel by DOJ. On the eve of the Senate's acquittal of Clinton in February 1999, it was reported that Attorney General Reno was considering whether to appoint a special investigative prosecutor to examine charges of possible misconduct by Starr. ${ }^{420}$ As this issue goes to print, the outlines of such an investigation are still taking form: DOJ has told Starr that it plans to open an inquiry into his operation, including his handling of Ms. Lewinsky at the outset of the inquiry and whether Starr failed to disclose possible conflicts of interest in January 1998 when he asked Attorney General Reno to expand his jurisdiction to investigate the Lewinsky matter. ${ }^{42}$

The obstacle to the inquiry is the conflict between Starr and Reno over how it will be conducted: The Attorney General wants to ensure that she retains her authority to discipline independent counsels; Starr maintains that no investigation should undercut his independence from DOJ. The question of whether an Attorney General has the authority to investigate an independent counsel is unresolved: There is no language in the Act relating to how an independent counsel would be investigated. Although the Attorney General has the power to remove an independent counsel under the Act, it is unclear whether this removal power also gives her the inherent power to investigate the independent counsel. The resolution of these questions will certainly impact the future of

418. See Alison Mitchell, Clinton Impeached, N.Y. TIMES, Dec. 20, 1998, § 1, at 1. The House voted on four charges brought against Clinton. The House approved a charge of perjury for misleading a federal grand jury about the nature of his relationship with Monica Lewinsky by a vote of 228 to 206 , and a charge of obstruction of justice by a vote of 221 to 212 . See id. The House rejected two charges: perjury in the Paula Jones sexual harassment suit and abuse of power stemming from Clinton's answers to 81 questions put to him in interrogatories by the House Judiciary Committee, by votes of 229 to 205 and 285 to 148 , respectively. See $i d$. A simple majority was needed to pass each charge. See U.S. CONST. art. I, \& 2, cl. 5 .

419. See Alison Mitchell, Clinton Acquitted Decisively, N.Y. TIMES, Feb. 13, 1999, at A1. The Senate rejected the perjury count by a 55 to 45 vote and the obstruction of justice count by a vote of 50 to 50. See id. A two-thirds majority would have been necessary to convict. See U.S. ConST. art. I, § 3 , cl. 6.

420. See U.S. Inquiry on Starr Is Seen, N.Y. TIMES, Feb. 9, 1999, at A17; see also David Johnston \& Don Van Natta Jr., Reno Considering Separate Counsel for Starr Inquiry, N.Y. TIMES, Feb. 19, 1999, at A1.

421. See David Johnston, Starr Puts up His Defense While Faulting Counsel Law, N.Y. TIMES, Apr. 15,1999 , at A28. Starr, testifying before the Senate Governmental Affairs Committee, which is considering changes in the Act, told the Committee that the Act was flawed and that it did not provide the public with a sense that investigations were nonpartisan. See id. 
the Act and the operation of future independent counsels and Attorneys General.

\section{E. Use of Grand Jury Materials}

An independent counsel investigation is bound by Federal Rule of Criminal Procedure Rule 6(e) and its bonds of secrecy for grand jury materials. ${ }^{422}$ The Federal Rules of Criminal Procedure state that "an attorney for the government ... shall not disclose matters occurring before the grand jury, except as otherwise provided for in these rules." ${ }^{, 423}$ A recent development in litigation involving the independent counsel has been the allegations of the wrongful use of secret federal grand jury testimony and materials by Independent Counsel Kenneth Starr and his office during the investigation of the Lewinsky matter.

In September 1998, the District Court for the District of Columbia ordered that the Office of the Independent Counsel and its individual members show cause why they should not be held in contempt for violating Rule 6(e) for disclosures contained in twenty-four news reports found by the court to contain prima facie violations of Rule 6(e) ${ }^{424}$ The various news reports, examined individually in detail by the court, relied on sources who were within or agents of the Office of the Independent Counsel and who revealed the strategy and direction of the independent counsel investigation, the targets of the grand jury investigation, the details of immunity negotiations with a potential grand jury target, and the contents of documents that were presented to the grand jury. ${ }^{43}$ The court denied Starr's request that it reconsider the ruling on the ground that fifteen of the twenty-four news accounts did not violate grand jury secrecy rules. ${ }^{426}$

The secrecy that attaches to grand jury proceedings also implicates the independent counsel's reports required by the Act. The Federal Rules of Crimi-

422. See In re North, 16 F.3d 1234, 1244 (D.C. Cir. 1994).

423. FED. R. CRIM. P. 6(e)(2). The language of Rule 6(e) expressly binds attorneys for the government; the independent counsel is unquestionably a government attorney. See North, 16 F.3d at 1242 (citing 28 U.S.C. \$ 594(a))

424. See In re Grand Jury Proceedings, Misc. No. 98-228, 1998 U.S. Dist. LEXIS 17290, at*34 (D.D.C. Sept. 24, 1998). This Order was issued after the district court already had once visited the issue, in June 1998. The district court had held that the news reports at issue established a prima facie violation of Rule 6(e)(2) and thus ordered a show cause hearing and established a set of procedures for the hearing. The Court of Appeals for the District of Columbia Circuit, hearing the independent counsel's petition for a writ of mandamus, reversed the district court. See In re Sealed Case, 151 F.3d 1059 (D.C. Cir. 1998) (per curiam). It was in this posture that the case returned to Chief Judge Norma Johnson; she appointed a Special Master, John W. Kern III, and established the procedures by which the show cause hearing would be conducted. See In re Grand Jury Proceedings, 1998 U.S. Dist. LEXIS 17290, at *34-*38. Although Judge Johnson issued the Order on September 24, it was not unsealed and made public until October 30. See Neil A. Lewis, Judge Cites Possible Improper Leaks by Starr Office, N.Y. TIMES, Oct. 31, 1998, at A9.

425. See In re Grand Jury Proceedings, 1998 U.S. Dist. LEXIS 17290, at *12-*32 (detailing the contents of the 24 news reports at issue and indicating what information therein established prima facie violations of Rule $6(\mathrm{e}))$.

426. See Neil A. Lewis, Starr Finds Nothing Wrong with Revealing Details of Talks, N.Y. TIMES, Jan. 7, 1999, at A26. Starr argued that eight of the news accounts involved negotiations between his office and Lewinsky's attorney at the time, William Ginsburg. See id. 
nal Procedure, however, make room for the inclusion of material in these reports, the release of which would otherwise violate the rule. The Rules state that "[d]isclosure otherwise prohibited by this rule of matter occurring before the grand jury may also be made ... . when so directed by a court preliminarily to or in connection with a judicial proceeding." ${ }^{427}$ Although the compilation of the independent counsel's final report is not itself a judicial proceeding, the decision to release the report is made by the Special Division, which must decide which portions are appropriate for release and what orders are appropriate for the protection of individuals named in it. ${ }^{428}$ Thus, any conflict between the reporting requirements of the Act and the rule of grand jury secrecy is avoided.

F. Conclusion: Relationships Created and Altered by the Operation of the Act

There are many complex relationships between an independent counsel and other actors in the political system: the public, the Special Division of the Court that oversees independent counsel investigations, the Attorney General and the Department of Justice, and Congress. Even if the Act expires in 1999 and is never reenacted, the case law the Act generated will remain on the books. The legal issues raised by the Act's interaction with other actors in the political system will persist no matter what the statutory language, or whether there is a statute at all. Future independent counsels or special prosecutors, under a renewed Act or otherwise, will have contentious relationships with DOJ, Congress, the courts, and others. Even an investigation conducted by DOJ personnel faces many of these same issues, the resolution of which will be informed by precedent generated by the operation of the Act. Politicians and investigators alike would be well served to learn from the legal principles and problems the Act exposed.

427. FED. R. CRIM. P. 6(e)(3)(C). "While Congress is silent on this exact subject, the nearest provision in the statute supports the view that the Independent Counsel is covered by Rule 6(e)." See North, 16 F.3d at 1244 (citing $\$ 594(k)(1)$, which states that "the independent counsel shall clearly identify which of these records are subject to Rule 6(e)"). The Special Division has the power to rule on motions concerning the disclosure of grand jury material in matters involving an independent counsel. See In re Sealed Motion, 880 F.2d 1367, 1373 (D.C. Cir. 1989) (per curiam).

428. The court held that such decisions constituted a "judicial proceeding" because the acts were taken in an adversarial proceeding involving a genuine case or controversy. See In re North, 16 F.3d 1234, 1244 (D.C. Cir. 1994). The court was very cautious to narrow the scope of its ruling: "We do not intend to formulate a rule that once a leak of Rule 6(e) material has occurred, government attorneys are free to ignore the pre-existing bond of secrecy." Id. at 1245 . The court continued, "We do not hold that the Independent Counsel is outside the coverage of Rule 6(e), we do hold that Rule 6(e) does not prevent release of the present Report." Id.

[T] he Independent Counsel as an attorney for the United States is covered by the strictures of Rule 6(e) of the Federal Rules of Criminal Procedure.... [W]e deny the motions that the Report be withheld on the basis of Rule 6(e), not because Rule 6(e) is ineffective against the Independent Counsel, but because in this case, the secrecy to be protected by Rule 6(e) no longer exists. 


\section{$\mathrm{V}$ \\ The Problem With PRIVILEgeS}

A popular Government, without popular information, or the means of acquiring it, is but a Prologue to a Farce or a Tragedy; or perhaps both. Knowledge will forever govern ignorance: And a people who mean to be their own Governors, must arm themselves with the power which knowledge gives. ${ }^{429}$

An open and transparent government is critical to a democratic political system. The people must know what goes on in government to be able to judge the behavior and accomplishments of elected officials and to hold these officials accountable for their actions. The use of evidentiary privileges in the criminal justice system undermines the accountability of government officials; excepting an individual from prosecution or from providing testimony not only deprives accused persons of a fair trial, but also prevents the general public from learning the truth about the internal workings of government. The accountability of the federal executive branch is particularly vulnerable when evidentiary privileges restrict or even prohibit the disclosure of information in furtherance of the President's constitutional responsibility to "take Care that the Laws be faithfully executed." ${ }^{430}$ An inherent conflict exists between fulfilling that duty by prosecuting those who violate the law and invoking evidentiary privileges to prevent the disclosure of information in the course of prosecution.

Evidentiary privileges have long been an integral part of the criminal justice system. The attorney-client privilege, for example, has been recognized as one of the oldest privileges for confidential communications in the common law. ${ }^{431}$ In addition, federal courts have been given the authority to recognize claims of privilege by Federal Rule of Evidence 501, which provides that

[e]xcept as otherwise required by the Constitution of the United States or provided by Act of Congress or in rules prescribed by the Supreme Court pursuant to statutory authority, the privilege of a witness, person, government, State, or political subdivision thereof shall be governed by the principles of the common law as they may be interpreted by the courts of the United States in the light of reason and experience.

Although the Supreme Court has never established a precise test for the recognition of evidentiary privileges, it has indicated the factors courts should consider in making a decision.

In investigations of wrongdoing, the invocation of privilege is problematic when potential witnesses can delay the investigation by providing various reasons why they should not answer questions or provide requested information.

429. Letter from James Madison to W.T. Barry (Aug. 4, 1822), in 9 WRITINGS OF JAMES MADISON 103 (Gaillard Hunt ed., 1910).

430. U.S. CONST. art. II, \& 3.

431. See Upjohn Co. v. United States, 449 U.S. 383, 389 (1981).

432. Federal and state precedent are given considerable weight, as is the existence of a public good requiring the court to ignore the established principle of taking every reasonable step to find the truth. The public good must be shown "with a high degree of clarity and certainty." In re Sealed Case, 148 F.3d 1073, 1076 (D.C. Cir. 1998); see also In re Bruce R. Lindsey (Grand Jury Testimony), 158 F.3d 1263 (D.C. Cir.), cert. denied sub nom. Office of President v. Office of Independent Counsel, 119 S. Ct. 466 (1998). 
This problem is especially severe when one branch of government is investigating its own members. Prior to the independent counsel statute, investigations aimed at activities within the executive branch were undertaken either by Congress or DOJ, itself a component of the executive branch. These investigations necessarily resulted in disputes either between the two elected branches of government, Congress and the President, or between two components of the executive branch, DOJ and the person within the executive branch claiming an evidentiary privilege.

United States $v$. Nixon ${ }^{433}$ makes clear that resolving such a dispute inevitably involves weighing competing interests, namely those of the party seeking disclosure against those of the party desiring confidentiality. Historically, when disputes arose within the federal government, the opposing branches would employ a system of accommodation through which they would try to negotiate a compromise. $^{434}$ According to former Assistant Attorney General William Barr, the Constitution's framers expected a spirit of dynamic compromise between the branches to result in an effective and efficient government. ${ }^{435}$ This process of compromise depends not only upon the competing needs for confidentiality and disclosure of information, but also upon each branch's consideration of the political viability of any given course of action. ${ }^{436}$ Rather than pressing for a decision that would absolutely define the "legitimate interest" of one of the branches, the parties would often negotiate, reaching a mutually acceptable solution given the political context and circumstances.

In the case of intra-executive branch disagreement, the President, after balancing the competing interests, makes the ultimate decision as the sole person constitutionally charged with the responsibility for law enforcement and for whatever other governmental interests are implicated by the situation. Even if the President himself is involved in the intra-executive dispute, the opposing parties must reach an informal resolution in a manner than can best accommodate the conflicting interests. ${ }^{438}$ As with congressional-executive disputes, these

433. 418 U.S. 683 (1974).

434. See William P. Barr, Congressional Requests for Confidential Executive Branch Information, 13 Op. Off. Legal Counsel 153, 157-61 (1989); see also Memorandum from President Reagan for the Heads of Executive Agencies on Procedures Governing Responses to Congressional Requests for Information (Nov. 4, 1982), reprinted in H.R. REP. No. 99-435, at 1106 (1985).

435. See Barr, supra note 434, at 158 (quoting United States v. AT\&T, 567 F.2d 121, 127, 130 (D.C. Cir. 1977)).

436. See id. at 159.

437. See Speech by Former Attorney General Richard Thornburgh at the Duke University School of Law (Sept. 16, 1998) [hereinafter Thornburgh speech].

438. See Matthew Cooper Weiner, Note, In the Wake of Whitewater: Executive Privilege and the Institutionalized Conflict Element of Separation of Powers, 12 J.L. \& POL. 775 (1996). After the Watergate scandal, the public generally perceived the executive privilege as a tool used by government officials to conceal important facts in order to deceive the public. Elected officials were then reluctant to invoke the executive privilege, and Presidents were reluctant to withhold too much information from both Congress and the public. The approaches that Ford, Carter, Reagan, and Bush took with respect to congressional requests for information show a genuine desire to accommodate congressional requests whenever possible. Although both Ford and Carter orally committed to an open presidency, 
specific accommodations are likely to vary according to context and circumstance. The parties lack an interest in attempting to articulate any bright-line standard for resolving the dispute for fear of lessening their future negotiating power. $^{439}$

The independent counsel statute creates a third scenario within which privilege disputes can occur: a dispute between the independent counsel and others in the executive branch. ${ }^{440}$ The independent counsel changes both DOJ's role and the dynamic of the negotiations over the release of privileged information. Because DOJ does not conduct the investigations when an independent counsel is involved, it no longer has a strong interest in protecting the integrity of the investigation by reaching a compromise between assertions of privilege and the need for evidence. As the government's lawyer, DOJ's sole responsibility in this situation is to protect the confidentiality of material the executive branch believes to be privileged.

Unlike DOJ prosecutors involved with privilege disputes between or within the elected branches of government, the independent counsel has no political accountability to the electorate either directly or indirectly, nor is he or she charged with responsibility for any other governmental interests besides conducting the investigation, which is defined by a specific and limited jurisdiction. ${ }^{441}$ For these reasons, the independent counsel has very different incentives and priorities for settling disputes over privilege than either the President or Congress. In determining what information should be privileged and what should be disclosed, for example, the independent counsel may value competing interests differently than would the political branches in an analogous situation, with consequences that affect any negotiated settlements. The incentives to avoid bright-line distinctions concerning the scope and applicability of the privileges are also different. While the elected branches have shied away from establishing bright-line rules, the independent counsel has no interest in avoiding a judicial resolution if it will expedite exploration of every possible avenue of factual inquiry or serve as an explanation for any inability to do so. ${ }^{442}$ Due to the limited jurisdiction of the investigation, the independent counsel has no incentive to consider the consequences a bright-line legal rule may have on future investigations or claims of privilege.

The remaining sections of Part $\mathrm{V}$ of the article examine crucial privilege issues that have arisen in the context of independent counsel investigations. These issues remain unresolved because the statute does not address the scope or the applicability of evidentiary privileges and because the Supreme Court has yet to consider how these privileges apply during an independent counsel

neither formally rejected the privilege, recognizing that in some circumstances the executive branch would have to preserve a degree of confidentiality in its communications. See id.

439. See id.

440. See Telephone Interview with Brenden V. Sullivan, Jr., Partner, Williams \& Connolly (Oct. 16, 1998) (notes on file with authors).

441. See 28 U.S.C. \& 593(b) (1994).

442. See Thornburgh speech, supra note 437. 
investigation, if at all. The discussion begins with executive privilege-in particular, a Supreme Court decision analyzing the privilege, United States $v$. Nixon, itself a product of a confrontation between an independent counsel-like investigator and the President. The next section explores issues that arise when the attorney-client privilege is asserted on behalf of a government attorney during an independent counsel investigation. The final section discusses the newly asserted protective function privilege claimed by the United States Secret Service.

\section{A. Executive Privilege}

\section{History of the Executive Privilege. The executive privilege}

exempts the executive from disclosure requirements applicable to the ordinary citizen or organization where such exemption is necessary to the discharge of highly important executive responsibilities involved in maintaining governmental operations, and extends not only to military and diplomatic secrets but also to documents integral to an appropriate exercise of the executive's domestic decisional and policy making functions. ${ }^{443}$

Although a formal executive privilege, also known as the presidential communications privilege, was not recognized by the courts until United States $v$. Nixon in 1974, Presidents have claimed the right to withhold information from both Congress and the public since the country's founding. The executive privilege protecting presidential communications is not contained in the text of the Constitution, but it is "inextricably rooted in the separation of powers under the Constitution," anny. The three branches of government perform independent functions and have independent responsibilities within a larger interdependent framework, a separation which prevents any one branch from accumulating too much power. ${ }^{445}$ Each branch must assert its own authority to prevent encroachment from the other branches. The nature of the President's enumerated powers and his unique role as the sole representative of the executive branch requires some degree of secrecy and dispatch if he is to have the power and flexibility to act in what he perceives to be the country's best interests.

Under the Constitution, the President alone is vested with the executive power. ${ }^{447}$ He serves as the "Commander in Chief of the Army and Navy of the United States, and of the Militia of the several States." make treaties, appoint ambassadors, public ministers, Supreme Court justices, and all other officers of the United States with the advice and consent of the

443. BLACK's LAW DICTIONARY 569-70 (6th ed. 1990) (citing 5 U.S.C. $\S 552(b)(1)(1988)$ ).

444. In re Sealed Case, 121 F.3d 729, 743 (D.C. Cir. 1997) (quoting Nixon v. United States, 418 U.S. 683,708 (1974)).

445. See Weiner, supra note 438 , at $784-85$.

446. See The Federalist No. 64, at 392 (John Jay) (Clinton Rossiter ed., 1961).

447. See U.S. CONST. art. II, \$ 1 , cl. 1.

448. Id. 
Senate, ${ }^{449}$ and he can recommend legislation to Congress for those measures that "he shall judge necessary and expedient." In exercising these responsibilities, the President is faced with complicated and sensitive decisions which only he can make. If he is to have the expert advice he needs to make informed decisions, he must be able to rely on "candid, objective, and even blunt or harsh opinions" from his inner circle of advisers and assistants. ${ }^{451}$ These advisers, in turn, are effective because of this assumption of confidentiality: "Human experience teaches that those who expect public dissemination of their remarks may well temper candor with a concern for appearances." 452 Therefore, the public, as the beneficiary of executive branch policies and agreements that result from having a well-informed President, has a strong interest in guaranteeing the confidentiality of executive communications.

Although the public benefits from the confidentiality of presidential decisionmaking, it also benefits from the constitutional checks and balances that prevent any one branch from expanding its powers beyond the Constitution's scope or from putting the activities of its members above the law. Therefore, the value of confidential executive conversations must be balanced against the powers and interests of the other branches and the general public. For example, the constitutional power of Congress to impeach and convict the President $^{453}$ requires the President to provide information upon a specific showing of need that he otherwise would like to keep confidential and privileged. ${ }^{454}$

Throughout history, Presidents have claimed the right to withhold information the confidentiality of which they considered vital to the performance of a presidential constitutional responsibility. For example, when faced with a congressional request for executive branch documents, George Washington first insisted that he had the privilege to withhold them in order to establish a precedent for future generations; later, he agreed to turn over the requested information to Congress. ${ }^{455}$ Similarly, during the negotiations of the Jay Treaty of

449. See id. $\S 2$, cl. 2.

450. Id. $\$ 3$.

451. United States v. Nixon, 418 U.S. 683,708 (1974).

452. Id. at 705 .

453. The House has the constitutional power to impeach the President, see U.S. CONST. art. I, $\S 2$, cl. 5, and the Senate has the power to convict, see id. \& 3, cl. 6 .

454. See Senate Select Committee on Presidential Campaign Activities v. Nixon, 498 F.2d 725 (D.C. Cir. 1974). The court held that conversations discussing the alleged crimes in Watergate were privileged even though they were outside the realm of official presidential duties. The committee did not demonstrate "an appropriate showing of public need," which turns "not on the nature of the presidential conduct that the subpoenaed material might reveal, but, instead... on whether the subpoenaed evidence is demonstrably critical to the responsible fulfillment of the committee's functions." Id. at 730-31. For further support of the idea that the President is not above the law, see Clinton v. Jones, 117 S. Ct. 1636 (1997) (allowing a private civil suit against the President to commence, but instructing that deference was owed to the President's unique constitutional position, and simultaneously not suggesting that the presumption of privilege for the President's communications was weakened).

455. See Weiner, supra note 438, at 793. Washington was asked to provide Congress with information concerning General Arthur St. Clair's failed military expedition against Native Americans. Although he turned the information over because he felt disclosure would not hurt the public interest, Washington asserted that the President had the right to withhold the information. See id. 
1795, Washington reasserted his privilege by refusing to supply information about the treaty negotiations to the House of Representatives when he felt doing so would be detrimental to the nation's interest. ${ }^{456}$

Consistent with this early precedent, the nineteenth-century executive branch traditionally withheld information concerning military, foreign, and sensitive domestic affairs, and, due to the nature of the information, the nineteenth-century Congress generally accepted the legitimacy of those decisions. ${ }^{457}$ In the early twentieth century, however, Presidents began to withhold a broader range of information and the practice of withholding such information became less accepted. Theodore Roosevelt, for example, withheld documents concerning the behavior of a company accused of violating the Sherman Antitrust Act. ${ }^{458}$ Franklin Roosevelt refused to give Congress FBI investigative files and ordered the FBI to ignore congressional subpoenas. ${ }^{459}$ Eisenhower dramatically expanded the scope of the executive privilege, invoking it between thirty and forty times, and Kennedy used the privilege to protect his military supervisor from testifying about the Bay of Pigs invasion and to prevent congressional oversight of foreign policy. ${ }^{460}$ Nixon, however, was the first President to invoke the executive privilege in a criminal investigation. It is notable that an independent counsel-like prosecutor, operating independently of the President and DOJ, was the instigator of the subpoena that culminated in United States v. Nixon.

2. The Nature of Executive Privilege: United States v. Nixon. ${ }^{461}$ Named an unindicted co-conspirator by the special prosecutor during a criminal investigation, President Nixon refused to comply with a third-party subpoena duces tecum requiring the production of certain tape recordings and documents that related to his conversations with aides and advisers. ${ }^{462}$ Nixon claimed that an absolute executive privilege protected the confidentiality of his conversations. ${ }^{463} \mathrm{He}$ also argued that the structure of American government and the doctrine of separation of powers insulated the President and the executive branch from a judicial subpoena in a criminal investigation. ${ }^{464}$

456. See id. at 794. For a general history of executive branch privilege claims, see History of Refusals by Executive Branch Officials to Provide Information Demanded by Congress: Part I-Presidential Invocations of Executive Privilege Vis-à-Vis Congress, 6 Op. Off. Legal Counsel 751 (1982).

457. See Weiner, supra note 438 , at 795.

458. See id.

459. See id.

460. See id. at 796-97.

461. Although the Supreme Court had never formally recognized executive privilege before Nixon, Chief Justice Marshall hinted in Marbury $v$. Madison that the courts might recognize such a privilege: He suggested that a court's intrusion "'into the secrets of the cabinet' would give the appearance of 'intermeddl[ing] with the prerogatives of the executive." Marbury v. Madison, 5 U.S. (1 Cranch) 137, 170 (1803). Marshall, however, did not "definitively decide whether . . the privilege existed" or what form it might take. In re Sealed Case, 121 F.3d 729, 738 (D.C. Cir. 1997).

462. See HARRIGER, supra note 5, at 42.

463. See Nixon v. United States, 418 U.S. 683, 688 (1974).

464. See id. at 706. 
According to Nixon, the executive privilege covering presidential communications had to be absolute to protect the frank and candid communications between the President and those who advise and assist him in performing his Article II duties. In supporting his particular claim of privilege, however, Nixon did not assert a specific need for confidentiality, such as protecting military, diplomatic, or sensitive national security secrets, but relied on "an undifferentiated claim of public interest in the confidentiality of such conversations." ${ }^{465}$ Lack of a specific need for confidentiality became a significant problem for Nixon because when the courts weigh "the public interest protected by the privilege against the public interests that would be served by disclosure in a particular case," the balance will lean toward the specific needs of a criminal investigation. ${ }^{466}$

Arguing against Nixon's general claim of executive privilege, the special prosecutor asserted a very specific need, derived from the constitutional commitment that no individual will be "deprived of life, liberty, or property, without due process of law." ${ }^{467}$ The Sixth Amendment of the Constitution guarantees all defendants the right "to be confronted with the witnesses against him" and "to have compulsory process for obtaining witnesses in his favor." suring that the guilty are punished and the innocent are acquitted after a fair trial requires the development of a full and complete factual record, a fundamental principle underlying the American criminal justice system. The invocation of evidentiary privileges flies directly in the face of this principle. The criminal justice system gives the public "a right to every man's evidence," therefore any exceptions to this right-whether found in the Constitution, statutes, or the tradition of common law-should not be "lightly created nor expansively construed, for they are in derogation of the search for truth." is especially true when a politically accountable member of the executive branch is being investigated.

Although the Supreme Court recognized that "the valid need for protection of communications between high Government officials and those who advise and assist them in the performance of their manifold duties ... is too plain to require further discussion," ${ }^{471}$ it found no guarantee of "an absolute, unqualified Presidential privilege of immunity from judicial process under all circumstances. ${ }^{, 72}$ Although beginning with a presumption of privilege ${ }^{473}$ the Court found that the specific need for the production of relevant evidence in a criminal proceeding could outweigh the privilege if the prosecutor could establish a

465. Id.

466. In re Sealed Case, 121 F.3d at 742 (quoting Nixon v. Sirica, 487 F.2d 700, 716 (D.C. Cir. 1973)).

467. U.S. CONST. amend. V.

468. Id. amend. VI.

469. In re Sealed Case, 121 F.3d at 756 (quoting Branzburg v. Hayes, 408 U.S. 665, 688 (1972)).

470. Id. at 749 .

471. United States v. Nixon, 418 U.S. 683, 705 (1974).

472. Id. at 706 .

473. See id. at 713. 
specific need for each and every piece of evidence subpoenaed. ${ }^{474}$ The Court was not concerned that infrequent disclosures of presidential conversations in the context of criminal prosecutions would have a chilling effect on the candor of presidential advisers because it felt that an in camera review of the materials in question would provide sufficient safeguard. ${ }^{475}$ Affirming the district court's decision that the material was essential, and requiring the information to be produced, the Supreme Court held that the President enjoyed a qualified but not an absolute executive privilege. ${ }^{476}$ The Court left open the possibility that if a President could show a specific need to keep particular communications confidential, that showing might prevent the need for information in a criminal investigation from overcoming the executive privilege. ${ }^{477}$

\section{Subsequent Cases Involving Claims of Executive Privilege.}

a. The Reagan years. In the controversy that would result in Morrison $v$. Olson, President Reagan instructed EPA Administrator Anne Gorsuch to withhold from Congress certain documents requested during the independent counsel's investigation of the "Superfund" clean-up. After the district court ordered the two branches of government to settle their differences without judicial intervention, Reagan agreed to release some documents, thus seeming, in the face of increasing political pressure, to back away from asserting the executive privilege. $^{478}$ Reagan did, however, assert executive privilege in response to a request for a memorandum written by then-Associate Justice Rehnquist regarding the nomination of Antonin Scalia to the Supreme Court. Reagan withdrew his privilege claim when the Democrats on the Judiciary Committee threatened to refuse to confirm Scalia.

Although President Reagan invoked the executive privilege in response to two other subpoenas-when asked to produce his diaries and when requested to testify about conversations regarding the Iran-Contra affair-the courts did not review the scope or function of the privilege in either situation. ${ }^{480}$ Recognizing that the executive privilege was implicated, the district courts nevertheless reviewed the subpoenas only for conformity with Federal Rule of Criminal Procedure $17(\mathrm{c}){ }^{481}$ In one case, the defendant, former National Security Adviser John Poindexter, was eventually pardoned, and the district court's order was never reviewed. ${ }^{482}$ In the other case, however, the court of appeals did review the district court's refusal to enforce a subpoena of President Reagan to

474. See id.

475. See id. at 714-16.

476. See id. at 712-14. President Nixon eventually waived his claim of executive privilege. See SPECIAL PROSECUTION ForCE, WATERGATE REPORT 99 (1975).

477. See Nixon, 418 U.S. at 712-14.

478. See Weiner, supra note 438 , at 803.

479. See id.

480. See In re Sealed Case, 121 F.3d 729, $743-44$ \& n.13 (D.C. Cir. 1997).

481. See id.

482. See id. (citing United States v. Poindexter, 921 F.2d 369 (D.C. Cir. 1991)). 
testify in the trial of Lt. Col. Oliver North. Although the court found that the subpoena should have been enforced, it held that the error was harmless because "there was no indication [Reagan] would have provided evidence that was material or favorable to North." 483 As a result, the issue of the privilege was not raised in the court's opinion. ${ }^{484}$

b. In re Sealed Case, ${ }^{485}$ June 1997. Responding to an independent counsel subpoena issued during an investigation of President Clinton's former Secretary of Agriculture Alphonso Michael Espy, the White House claimed that the executive privilege protected the White House Counsel's notes of internal meetings concerning Espy, along with notes regarding conversations between Espy or his counsel and White House employees. ${ }^{486}$ Following an in camera review of the notes, the district court denied the motion to compel the production of the notes, holding that the White House had properly asserted the privilege without actually discussing the documents or providing an analysis of the grand jury's need. ${ }^{487}$

On appeal, the Office of the Independent Counsel ("OIC") argued against the applicability of the executive privilege on three grounds. First, it claimed that the White House had waived the executive privilege by releasing the final investigative report, stating to the press that it would comply with the subpoena, and unduly delaying its invocation of the privilege. ${ }^{488}$ Second, OIC asserted that because President Clinton never saw any of the documents in question (with the exception of the publicly released final report), the executive privilege could not protect materials that were neither "sent to [nor] received from the President." 489 Third, OIC insisted that even if the executive privilege applied, the district court erred in applying the Nixon standard for determining the weight of the grand jury's need for the documents because that standard applied to a criminal trial subpoena, not a grand jury subpoena. ${ }^{490}$ According to OIC, greater weight should have been given to a grand jury subpoena, which, in this case, should have outweighed the executive privilege. ${ }^{491}$ Among its responses, the White House denied that the privilege was waived. It argued that the claim of executive privilege rested on the fact that the documents were cre-

483. Id. (citing United States v. North, 910 F.2d 843, 888-92 \& n.25 (D.C. Cir.), vacated in part, 920 F.2d 940 (D.C. Cir. 1990)).

484. See id.

485. 121 F.3d 729 (D.C. Cir. 1997).

486. See id. at 734-35. Espy was being investigated for allegedly "improperly accept[ing] gifts from individuals and organizations with business before the U.S. Department of Agriculture." Id. For a discussion of other aspects of the Espy investigation, see supra notes 281-303 and accompanying text.

487. See 121 F.3d at 736 .

488. See id.

489. Id.

490. See id.

491. See id. 
ated in response to the President's request for advice about whether to retain a cabinet officer-advice concerning a core Article II function. ${ }^{492}$

The court agreed with the White House that the privilege was not waived. The press statement was seen as an unofficial response to the subpoena, saying simply that the White House would "comply" with the subpoena without explicitly saying that it would forgo any and all claims of privilege. ${ }^{493}$ Furthermore, the White House had informed OIC that some of the material was privileged shortly after the press statement was issued, despite having no obligation to formally invoke the privilege in advance of a motion to compel. ${ }^{49}$

With respect to the release of the report, the court distinguished the executive privilege from the attorney-client privilege, in which the voluntary disclosure of some privileged material waives the privilege with respect to the remaining material. The court reasoned that voluntary disclosure would be encouraged by allowing executive branch agencies to release some material without compromising their potential claims of executive privilege to protect the remaining material. Therefore, although the final report was no longer privileged, the rest of the documents remained protected by the executive privilege. 495

After determining that the privilege had not been waived, the court turned to the question of how far removed a conversation could be from direct presidential involvement to remain within the scope of the privilege ${ }^{496}$ Because the privilege arises from the President's role as the chief constitutional officer of the executive branch, the court construed the privilege "as narrowly as is consistent with ensuring that the confidentiality of the President's decision-making process is adequately protected." 497 The privilege had to be interpreted broadly enough to enable the President to carry out his Article II functions, without excluding too large an array of materials from public view (which would harm both the criminal justice system and the American system of political accountability). ${ }^{498}$

To carry out his Article II functions, the President relies on the advice of his aides and advisers. Because conversations among advisers and the documents they produce are important components of the advice ultimately given to the President, they are "usually highly revealing" of the ultimate decisions. ${ }^{499}$ If information were protected only when it reached the President in finished form, the concept of executive privilege would lose its meaning and inhibit the freedom of presidential advisors to voice opinions fully and frankly. To prevent a chilling effect, the court therefore had to determine the point at which failing to

492. See id.

493. See id. at $740-41$.

494. See id. at 741.

495. See id. at 741-42.

496. See id. at 746-53.

497. Id. at 752 .

498. See id. at 749.

499. Id. at 750 . 
protect such conversations would "impede the President's ability to perform his constitutional duty."

In the court's view, communications of presidential advisers made in the course of preparing advice on official government matters for the President were within the scope of the privilege regardless of whether the President was present: ${ }^{501}$ "[C]ommunications authored or received in response to a solicitation by members of a presidential adviser's staff ${ }^{\text {"502 }}$ were also covered by the privilege because presidential advisers often rely on their staffs "to investigate an issue and formulate the advice to be given to the President."

To be consistent with Nixon, however, the court could not recognize an absolute executive privilege. OIC could overcome the White House's claim of executive privilege if it met the standard of need established by Nixon. Specifically, OIC first would need to show that "each discrete group of subpoenaed materials likely contains important evidence" that would be directly relevant to the central issues of the trial. ${ }^{504}$ Second, OIC would need to prove that the material could not be available elsewhere with "due diligence." such a showing, the White House would have to provide a detailed explanation of why the material must be privileged. The court then would weigh the competing public interests of ensuring the confidentiality of the presidential decisionmaking process and of maintaining an open and accountable government. ${ }^{506}$

On the merits, the court held that although the executive privilege could apply to all the documents because "OIC has demonstrated a sufficient showing of need to obtain certain information in some of the documents," the case was remanded to the district court to determine what information should remain privileged and what should be released. ${ }^{507}$

c. In re Grand Jury Proceedings, ${ }^{508}$ May 1998. In support of their refusal to answer questions during a grand jury investigation, top White House aides Bruce Lindsey and Sidney Blumenthal ${ }^{509}$ claimed that the executive privilege protected the confidentiality of their conversations with President Clinton and other White House officials concerning Monica Lewinsky and Paula Jones. ${ }^{510}$

500. Id. at 751 (quoting Morrison v. Olson, 487 U.S. 654, 691 (1988)). The court distinguished the more general deliberative process privilege, finding that it offered inadequate protection for communications that needed to remain confidential because it did not protect purely factual material. See id. at 750 .

501. See id. at 752 .

502. Id.

503. Id.

504. Id. at 754.

505. Id. The second element raises the standard of need above the requirement of relevance necessary for a subpoena under Federal Rule of Criminal Procedure 17(c). See id.

506. See id. at 756 .

507. See id. at 757 .

508. 5 F. Supp. 2d 21 (D.D.C. 1998).

509. Bruce Lindsey holds positions as both Deputy White House Counsel and Assistant to the President. Sidney Blumenthal is an Assistant to the President.

510. See In re Grand Jury Proceedings, 5 F. Supp. $2 \mathrm{~d}$ at 24. 
According to the White House, the conversations were privileged because they concerned possible impeachment proceedings, domestic and foreign policy matters, and assertions of official privileges - all of which aid the President in carrying out his constitutional Article II functions. ${ }^{511}$ To prove that the privilege was not being abused, the White House pointed out that although Lindsey had testified before the grand jury three times, he invoked the executive privilege only when questioned about communications designed to aid the President in the execution of his official duties. ${ }^{512}$ In challenging OIC's interpretation of Nixon, which suggested that all private conversations are outside the sphere of the executive privilege, the White House pointed out that in Senate Select Committee, ${ }^{513}$ Nixon's conversations with John Dean about alleged criminal acts were held to be presumptively privileged. ${ }^{514}$ The White House emphasized that these conversations concerned official matters, including the official conduct of the President, to which the executive privilege should certainly apply. According to the White House, although Nixon established that a specific showing of need during the course of a criminal investigation could outweigh the executive branch's general need for confidentiality, there was no such showing here. ${ }^{515}$

In moving to compel the testimony of Lindsey and Blumenthal, OIC argued that the privilege did not apply because the communications did not relate to official decisionmaking or to advice regarding the execution of Article II duties. Private communications fall outside the sphere of the executive privilege because the President does not carry out Article II responsibilities in his capacity as an individual. ${ }^{516}$ According to OIC, without a "'need to protect military, diplomatic, or sensitive national security secrets,' the President's 'generalized interest in confidentiality ... cannot prevail over the fundamental demands of due process of law in the fair administration of criminal justice.",517

Absent actual proof that the conversations did not relate to some aspect of the President's official duties or to presidential decisionmaking, the district court did not consider the communications to be outside the limited scope of

511. See id. at 26 (noting that the court received sworn affidavits regarding the content of the conversations).

512. See Memorandum of the White House in Opposition to OIC's Motions to Compel Bruce R. Lindsey and Sidney Blumenthal to Testify Concerning Conversations Protected by the AttorneyClient, Presidential Communications and Work Product Privileges, In re Grand Jury Proceedings, 5 F. Supp. 2d 21 (D.D.C. 1998) (Mar. 17, 1998) (on file with authors) [hereinafter, White House Opposition Memo].

513. Senate Select Committee on Presidential Campaign Activity v. Nixon, 498 F.2d 725 (D.C. Cir. 1974).

514. See White House Opposition Memo, supra note 512, (citing Senate Select Committee, 498 F.2d at 730 ).

515. See id.

516. See United States v. Nixon, 418 U.S. 683, 705-06 (1974).

517. Petition for a Writ of Certiorari Before Judgment to the United States Court of Appeals for the District of Columbia Circuit, at subheading "Reasons for Granting the Writ" II 3, Office of President v. Office of Independent Counsel, 119 S. Ct. 466 (1998) (quoting Nixon, 418 U.S. at 706, 713) (on file with authors). 
executive privilege. ${ }^{518}$ In fact, the court received sworn affidavits that the conversations concerned official duties. ${ }^{519}$ The court found no precedent for declining to treat presidential communications as presumptively privileged on the ground that they discussed the personal rather than official conduct of the President. ${ }^{520}$ Due to the constitutional uniqueness of the presidency and the ramifications of a President's personal conduct, separating purely personal conversations from official conversations is extremely difficult. Even OIC conceded that certain communications concerning the President's personal conduct, "such as those discussing how the President should respond to the Lewinsky matter during [British Prime Minister] Tony Blair's visit," were "protected by executive privilege." ${ }^{521}$

Consistent with earlier precedent, however, the court also held that the presumption of privilege could be and actually was rebutted by a sufficient showing of need. OIC had established such a need by meeting the criteria outlined in In re Sealed Case, which requires the prosecution to show "first, that each discrete group of the subpoenaed materials likely contains important evidence; and second that this evidence is not available with due diligence elsewhere." Simply asserting the OIC's general power to investigate would not suffice. Although the court could not describe the contents of the evidence subpoenaed because Federal Rule of Criminal Procedure 6(e)(2) prohibits revealing any part of a grand jury proceeding, the court decided, after an in camera review, that the information was likely to contain evidence important to the investigation. Furthermore, OIC lacked other means to obtain information regarding conversations that these men had with the President and his aides and advisers. ${ }^{523}$

On the merits, the court held that Lindsey's and Blumenthal's legitimate claims of executive privilege were outweighed by the need for the evidence in a criminal investigation, and, consequently, their testimony was compelled by the court. $^{524}$

518. See In re Grand Jury Proceedings, 5 F. Supp. 2d 21, 26 (D.D.C. 1998).

519. See id. at 26.

520. See id. at 25; see also In re Sealed Case, 121 F.3d 729, 749 (D.C. Cir. 1997); Nixon, 481 U.S. at 708. The subpoenaed materials in Nixon were considered presumptively privileged despite the fact that they concerned the President's alleged criminal involvement in the Watergate break-in.

521. In re Grand Jury Proceedings, 5 F. Supp. $2 \mathrm{~d}$ at 26.

522. In re Grand Jury Proceedings, 5 F. Supp. 2d at 28 (quoting In re Sealed Case, 121 F.3d 729, 754 (D.C. Cir. 1997)); see also supra Part V.A.3.b (discussing In re Sealed Case in detail). According to the court, requiring that the desired evidence be directly relevant to the central issues of the trial would not have much impact because Federal Rule of Criminal Procedure 17(c) already limits the use of a subpoena to relevant information.

523. See In re Grand Jury Proceedings, 5 F. Supp. $2 \mathrm{~d}$ at 29.

524. See id. at 27 . The claims of executive privilege were not raised when Lindsey appealed the decision that a governmental attorney-client privilege did not apply. See In re Bruce R. Lindsey (Grand Jury Testimony), 158 F.3d 1263, 1267 (D.C. Cir.), cert. denied sub nom. Office of President v. Office of Independent Counsel, 119 S. Ct. 466 (1998). 
4. Conclusion. Although general claims of an executive privilege have been overcome by the specific need for information in grand jury investigations, the limited case precedent keeps open the possibility that a specific need for confidentiality may prevail. Neither the Supreme Court nor the executive branch has been willing to establish a bright-line rule defining when the privilege will or will not apply. In fact, the executive branch has avoided such a rule by failing to appeal lower court decisions limiting the scope of the executive privilege. ${ }^{525}$ Because the independent counsel statute does not address the issue of privileges and because the issue has not been widely litigated, Congress may find it necessary to establish the privilege's scope more clearly within the context of an independent counsel investigation.

\section{B. Attorney-Client Privilege}

1. The History of Attorney-Client Privilege. Federal Rule of Evidence 501 provides that "the privilege of a witness ... shall be governed by the principles of the common law as they may be interpreted by the courts of the United States in light of reason and experience." The Supreme Court has recognized that "[ $t]$ he attorney-client privilege is one of the oldest of the privileges for confidential communications known to the common law." ${ }^{256}$ In an adversarial system, an attorney needs to be trusted with "all that relates to the client's reasons for seeking representation if the professional mission is to be carried out." ${ }^{527}$ The reassurance that all communications are protected is critical in encouraging clients to fully disclose all pertinent facts to their attorneys in order to receive the best legal advice. ${ }^{52}$

The attorney-client privilege exists between attorneys and corporations as well as between attorneys and natural persons. ${ }^{529}$ However, the application of the privilege in the corporate context presents different problems. Often, those persons receiving legal advice and making decisions may not be the persons who can best supply the facts. Therefore, to protect the exchange of both facts and professional advice, the application of the privilege is not constrained to a single person within the corporate hierarchy, but instead includes conversations for the purpose of the corporation's legal representation between the corporation's attorneys and any employees. ${ }^{530}$ Although the Supreme Court has recognized that the privilege applies to both individuals and corporations, it has never established whether the attorney-client privilege exists between govern-

525. See, e.g., id. at 1267.

526. Upjohn Co. v. United States, 449 U.S. 383, 389 (1981).

527. Id. (quoting Trammel v. United States, 445 U.S. 40, 51 (1980)).

528. See id. The attorney-client privilege "is founded upon the necessity, in the interest and administration of justice, of the aid of persons having knowledge of the law and skilled in its practice, which assistance can only be safely and readily availed of when free from the consequence of the apprehension of disclosure." Id. (quoting Hunt v. Blackburn, 128 U.S. 464, 470 (1888)).

529. See generally id. at 386 (holding that the attorney-client privilege was applicable in the corporate context).

530. See id. at 390-91. 
ment attorneys and government institutions, and, in fact, has repeatedly turned down the opportunity to do so. ${ }^{531}$

2. Special Problems Concerning a Governmental Attorney-Client Privilege. A governmental attorney-client privilege cannot be established by analogy to a corporate attorney-client privilege because government and private entities raise different problems of accountability. Government entities, for example, cannot be held criminally liable for employee actions. ${ }^{532}$ Without this liability, they have less incentive to investigate employee misconduct and courts have less reason to establish an attorney-client privilege protecting confidential communications in order to ensure that the results of internal investigations are shared. ${ }^{533}$ Another difference exists between the nature of the responsibilities of government employees and the nature of the responsibilities of private employees. For example, a conflict may develop between the private interests of an executive branch employee and the public interests he or she represents when acting in an official capacity. ${ }^{534}$ A private employee, on the other hand, does not have to consider the public's best interests.

The many characteristics that distinguish government attorneys from private attorneys further hinder this analogy. While private attorneys have a single duty to represent their clients zealously, government attorneys must balance their dual roles as law enforcement officials and zealous advocates for individual clients. Government attorneys must ensure that their government clients are faithfully following the law, and that in doing so they are pursuing the public's best interest. ${ }^{535}$ The tensions among the different responsibilities of the government attorneys create problems for courts deciding the scope of the governmental attorney-client privilege. On the one hand, government attorneys are servants of the public, and as executive branch attorneys, they have the duty to counsel for openness and transparency in the government. On the other hand, they must zealously represent the legal interests of the government, a responsibility that requires the same guarantee of confidentiality that a private or corporate lawyer does. The competing responsibilities of government attorneys and the disparate interests of the government employees they represent raise two unanswered critical questions: Who is the client, and what responsibility does the government attorney have with respect to that client? ? $^{536}$

531. See In re Grand Jury Proceedings Subpoena Duces Tecum, 112 F.3d 910, 920 (8th Cir.), cert. denied sub nom. Office of President v. Office of Independent Counsel, 117 S. Ct. 2482 (1997); see also In re Bruce R. Lindsey (Grand Jury Testimony), 158 F.3d 1263 (D.C. Cir.), cert. denied sub nom. Office of President v. Office of Independent Counsel, 119 S. Ct. 466 (1998).

532. See In re Grand Jury Proceedings Subpoena Duces Tecum, 112 F.3d at 920.

533. See id.

534. See id. at 922 .

535. See Federal Bar Association Ethics Committee, The Government Client and Confidentiality: Opinion 73-1, 32 FED. B.J. 71, 72 (1972).

536. See generally Symposium, Government Lawyering, 61 LAW \& CONTEMP. PROBS. 1 (Winter \& Spring 1998). 
Executive branch employees have a statutory duty under 28 U.S.C. § 535(b) to report the criminal wrongdoing of other employees to the Attorney General. ${ }^{537}$ The statute provides that "[a]ny information received in a department or agency of the executive branch of the Government relating to violations of title 18 involving Government officers and employees shall be expeditiously reported to the Attorney General." ${ }^{538}$ This requirement has been interpreted in two different ways. According to one interpretation, the requirement simply gives the Attorney General the authority to conduct investigations. Under another interpretation, full disclosure of all possible criminal violations would be required ${ }^{539}$ even information relayed under a belief of privilege between a government lawyer and an employee. In the case of an independent counsel investigation, possible criminal violations would have to be reported to the independent counsel, who holds the responsibilities of the Attorney General for that particular investigation. ${ }^{540}$ The latter interpretation vitiates the attorneyclient privilege.

A government attorney also has a responsibility as a public servant that may militate against his client's interest by voiding their common law attorneyclient privilege. In their capacity as public servants, government attorneys must "favor disclosure over concealment" ${ }^{\text {"541 }}$ because the public has the right to know what its representatives are doing and what stands they are taking on the important issues. For this reason, the government lawyer's obligation to "uphold the public trust ${ }^{, 542}$ may conflict with his client's need to use the in-house counsel "as a shield against the production of information relevant to a federal criminal investigation"; allowing a government lawyer to create barriers that prevent transparency in government "represent[s] a gross misuse of public assets." ${ }^{543}$

While the public has an interest in knowing what occurs behind the closed doors of government, it also has an interest in making sure that public officials are able to fulfill their constitutional and statutory responsibilities. For this reason, the President and other executive branch officials must be fully informed about the legal consequences of any decisions they make. To provide the best possible legal advice, government attorneys, like attorneys for individuals or private corporations, need complete disclosure of factual information. ${ }^{544}$ If the need for full disclosure of facts justifies an attorney-client privilege for natural persons and corporations, that same need should justify the privilege in the governmental context. The conflict between disclosure and

537. See In re Grand Jury Subpoena Duces Tecum, 112 F.3d at 920.

538. 28 U.S.C. $\$ 535$ (b) (1994).

539. See Michael Stokes Paulsen, Hell, Handbaskets, and Government Lawyers: The Duty of Loyalty and Its Limits, 61 LAW \& CONTEMP. PROBS. 83, 96-101 (Winter 1998).

540. See In re Bruce R. Lindsey (Grand Jury Testimony), 158 F.3d 1263, 1274 n.6 (D.C. Cir.), cert. denied sub nom. Office of President v. Office of Independent Counsel, 119 S. Ct. 466 (1998).

541. In re Grand Jury Subpoena Duces Tecum, 112 F.3d at 920.

542. See In re Bruce R. Lindsey (Grand Jury Testimony), 158 F.3d at 1273-74.

543. In re Grand Jury Subpoena Duces Tecum, 112 F.3d at 921.

544. See id. at 926 (Kopf, J., dissenting). 
confidentiality is further complicated when the client is the President of the United States and the privilege is invoked in a criminal investigation. The President, as the sole organ of the executive branch, is ultimately responsible for enforcing the law. Because the invocation of the attorney-client privilege hampers law enforcement by preventing the disclosure of evidence, the President, as chief law enforcement officer of the United States, must have good reason to invoke it. This is especially true in the context of a criminal investigation because investigating and prosecuting federal crimes is central to the duty of members of the executive branch, who are bound by oath to uphold their constitutional responsibility to "take Care that the Laws be faithfully executed." "545 Invoking a privilege that impedes a federal grand jury's investigation seems to contradict this important responsibility of the office. For these reasons, asserting a governmental attorney-client privilege requires more than a simple claim of presidential need for confidential relationships with his government attorney. ${ }^{546}$ More specialized rules may be needed to "take account of the complex considerations of governmental structure, tradition and regulation that are involved." 547 Just what these special considerations may include, however, has yet to be determined.

A final consideration in the debate regarding governmental attorney-client privilege arises from its overlap with executive privilege, both of which aim to ensure that the President receives full, open, and honest communications with his aides, advisers, and attorneys. Although the attorney-client privilege is absolute in the private sphere, the unique responsibilities of executive branch lawyers may require qualifying the attorney-client privilege in the public sphere-in the same way that the executive privilege is qualified. ${ }^{548}$ Some argue that the attorney-client privilege should not be used to shield communications that would not be covered by the executive privilege, because doing so might allow the President to avoid the recognized limitations of executive privilege. On the other hand, the two privileges are intended to cover very different types of communications. The application of the appropriate privilege should depend upon whether the communications involved political, strategic, or policy issues (executive privilege), or legal advice (attorney-client privilege).

a. Watergate and the Iran-Contra affair. Until the Clinton Administration, the White House generally avoided litigation with OIC concerning the scope of the attorney-client privilege. For example, Nixon White House Counsel Fred Buzhardt testified before the Watergate grand jury without invoking the attorney-client privilege. ${ }^{549}$ This willingness to testify, however, did not mean that the privilege could not be invoked, as the Bush

545. U.S. CONST. art. II, § 3.

546. See In re Bruce R. Lindsey (Grand Jury Testimony), 158 F.3d at 1271-72.

547. Id. at 1272.

548. See In re Grand Jury Subpoena Duces Tecum, 112 F.3d at 926 (Kopf, J., dissenting).

549. See In re Bruce R. Lindsey (Grand Jury Testimony), 158 F.3d at 1275 (citing Anthony Ripley, Milk Producers' Group Fined \$5,000 for Nixon Gifts, N.Y. TiMES, May 7, 1974, at 38). 
Administration made clear when complying with OIC requests during the IranContra investigation. Bush White House Counsel C. Boyden Gray and Deputy White House Counsel John Schmitz made compliance with subpoenas contingent upon agreement by OIC that their right to claim evidentiary privileges, including the attorney-client privilege, was not waived. Once this agreement was reached, some of the requested documents were turned over. ${ }^{550}$ Reagan White House Counsel Peter Wallison even produced his diary for OIC. These investigatory requests, unlike those during the Clinton Administration, were not made in an investigation regarding the criminal activity of the President or the First Lady, and OIC did not subpoena testimony from either Reagan or Bush. ${ }^{551}$

b. In re Grand Jury Subpoena Duces Tecum, ${ }^{552}$ April 1997. In refusing to comply with OIC's subpoena for "all documents created during meetings attended by any attorney from the Office of the President and Hillary Rodham Clinton ... pertaining to several Whitewater-related subjects," the White House claimed that the executive privilege, the attorney-client privilege, and the attorney work-product doctrine protected the document's confidentiality. ${ }^{553}$ Treating this assertion of attorney-client privilege as a de novo assertion of privilege, the Eighth Circuit Court of Appeals concluded that although the governmental attorney-client privilege existed in some situations, it did not exist with respect to a grand jury investigation. ${ }^{54}$

The two parties approached this question from diametrically opposed positions. OIC viewed recognition of a governmental attorney-client privilege as an unacceptable expansion of the common law privilege, "tantamount to establishing a new privilege." 555 Because government attorneys, as law enforcement officials in the executive branch, have a duty under 28 U.S.C. $\$ 535$ (b) to report criminal law violations by executive branch officers to the Attorney General and because of their responsibility to protect the public interest, OIC argued that the government attorney's relationship to governmental clients was different from the relationship between private attorneys and private clients. Due to these fundamental differences, OIC claimed that a privilege protecting conversations between private attorneys and private clients could not be used to protect conversations between government attorneys and government clients. Ac-

550. See id. (citing 1 WALSH, supra note 113 , at $478-79$ \& n.52 (1993)).

551. See id.

552. See In re Grand Jury Subpoena Duces Tecum, 112 F.3d at 910.

553. Id. at 913 (quoting Subpoena Rider at 1). This investigation concerned matters "relating in any way to James B. McDougal's, President William Jefferson Clinton's, or Mrs. Hillary Rodham Clinton's relationships with Madison Guaranty Savings \& Loan Association, Whitewater Development Corporation or Capital Management Services, Inc." See Order at 1-2, In re Madison Guar. Sav. \& Loan Ass'n, Div. No. 94-1 (D.C. Cir. Aug. 5, 1994).

554. See In re Grand Jury Subpoena Duces Tecum, 112 F.3d at 915.

555. Id. 
cording to OIC, protecting the latter would require impermissibly expanding the privilege, something that judges are generally very reluctant to do.

The White House, on the other hand, argued that as the oldest known privilege in the common law, the absolute attorney-client privilege, applies to individuals, to corporations, and to the government. ${ }^{557}$ The White House found support in federal legislation that assumes the existence of a governmental attorney-client privilege. Specifically, Proposed Federal Rule of Evidence 503(a)(1) defines a client as "a person, public officer, or corporation, association, or other organization or entity, either public or private."

The White House also referred to other civil and criminal cases in which a claim of governmental attorney-client privilege had been invoked, but the court found none of these cases persuasive. ${ }^{559}$ In the criminal cases, the courts never actually applied the attorney-client privilege to block the investigation because the cases were remanded before the issue was addressed. ${ }^{560}$ In the civil cases, the inherent disparity between requests made under the Freedom of Information Act and requests made in the course of a federal criminal investigation prevented the former from establishing a precedent applicable to the latter.

Without clear precedent either establishing or rejecting the governmental attorney-client privilege, the court examined the two main cases from which the parties drew inferences regarding its scope. ${ }^{561}$ When determining the applicability of these cases, the court kept in mind two general principles: (1) "the public... has a right to every man's evidence" and (2) "privileges, as exceptions to the general rule, 'are not lightly created nor expansively construed.'

Although Nixon dealt with a claim of executive privilege, the court felt that its basic premise-that the government's general need for confidentiality may be outweighed by a specific need for facts in a criminal investigationcounseled against establishing an attorney-client privilege in this case. According to the court, the White House's analogy to the common law attorneyclient privilege recognized in Nixon and applied to corporations in Upjohn was inapposite because of the substantial differences between governmental and nongovernmental organizations and attorneys. ${ }^{563}$ Both this duty and the general responsibility of public servants to "favor disclosure over concealment" in

556. See id.

557. See id.

558. PROPOSED FED. R. EVID. 503(a)(1), reprinted in 36 F.R.D. 183, 260 (1972).

559. See In re Grand Jury Subpoena Duces Tecum, 112 F.3d at 917-18.

560. See id. at 917.

561. The parties relied primarily on United States v. Nixon, 418 U.S. 683 (1974), and Upjohn v. United States, 449 U.S. 383 (1981).

562. In re Grand Jury Subpoena Duces Tecum, 112 F.3d at 918.

563. See id. at 920 . The court compared this situation to the Supreme Court's refusal to recognize a work-product immunity for public accountants based on the differences between the public and private interest. Independent auditors have a public responsibility which transcends any duty to their clients because of the special duty they have to inform the public about the true financial situation of the corporation. The court argued that a government attorney is in a similar situation: the duty to inform the public that elected officials are violating the law that transcends the attorney's responsibilities with respect to the government official. See id. 
a representative government would be undermined if a governmental attorneyclient privilege prevented facts from being disclosed. ${ }^{564}$ The court further reasoned that the absence of an attorney-client privilege in this context would not have the chilling effect on internal investigations of possible liability-creating misconduct that it would in the corporate context because the White House does not have the same incentive to conduct such investigations. ${ }^{565}$ Employees of the executive branch are under a statutory duty to report the criminal wrongdoings of other employees to the Attorney General, ${ }^{566}$ and cannot themselves subject the White House to criminal liability for their actions.

In addition, the court held that government officials are free to speak with private attorneys when confidentiality is needed. ${ }^{567}$ Because a government attorney's role is to explain the law so that public officials can obey it, these types of communications would not be chilled by the possibility of disclosure. ${ }^{568}$

The court also rejected the White House argument that the commoninterest doctrine extended the attorney-client privilege that Mrs. Clinton shared with her personal attorney to cover communications made in the presence of White House attorneys. ${ }^{569}$ According to the White House, two clients were present at the meetings, Mrs. Clinton in her personal capacity and Mrs. Clinton as a representative of the White House, and both shared a common interest in obtaining an accurate understanding of their legal situation and the courses of action available. The court found no such interest. ${ }^{570}$ In her personal capacity, Mrs. Clinton wanted to minimize the possibility of prosecution by OIC, but the White House, as an institution, had no such interest. ${ }^{571}$ The court therefore rejected the argument that the attorneys were allocating responsibility among themselves in order to achieve a common goal that went beyond simply obeying the law. Obeying the law itself was not sufficient justification for the application of the privilege. ${ }^{572}$ Lastly, the court rejected the argument for confidentiality based on Mrs. Clinton's belief that the conversations were privileged, reasoning that the law rarely factors in the actor's beliefs at the time of the action. ${ }^{573}$

The panel of judges, however, was neither unanimous in its decision nor in how it approached the issue. In his dissenting opinion, Judge Kopf advocated

564. See supra text accompanying notes 533-535.

565. See In re Grand Jury Subpoena Duces Tecum, 112 F.3d at 920-21.

566. See 28 U.S.C. \& 535(b) (1994).

567. See In re Grand Jury Subpoena Duces Tecum, 112 F.3d at 921.

568. See id.

569. See id. at 922. The common-interest doctrine expands the attorney-client privilege in certain situations. "If two or more clients with a common interest in a litigated or non-litigated matter are represented by separate lawyers, and they agree to exchange information concerning the matter, a communication of any such client that otherwise qualifies as privileged ... that relates to the matter is privileged as against third parties." Id.

570. See id.

571. See id.

572. See id.

573. See id. at 923. 
the application of the Nixon balancing test. ${ }^{574} \mathrm{He}$ argued that Nixon did not stand for the proposition that the White House altogether lacked the attorneyclient privilege. ${ }^{575} \mathrm{He}$ found support for a governmental attorney-client privilege in common law precedent, the proposed Restatement of the Law (Third) Governing Lawyers, and Proposed Federal Rule of Evidence 503. According to the Restatement, the attorney-client privilege " extends to a communication of a governmental organization' and to 'an individual officer, employee, or other agent of a governmental organization.","576 Proposed Rule 503 "plainly grants the White House the attorney-client privilege" by extending the privilege to "organizations or entities, either public or private." "577 Although Congress failed to enact it, the Supreme Court's recommendation of the proposed rule to Congress implicitly supported the existence of such a privilege. Furthermore, Judge Kopf felt this interpretation accurately reflected the federal common law of attorney-client privilege. ${ }^{578} \mathrm{He}$ rejected the argument that the privilege would not apply in criminal cases involving government entities, and he argued that Proposed Rule 503 does not distinguish between civil and criminal cases, and that no case law suggests the privilege has been denied in criminal situations. ${ }^{579}$ In fact, courts have supported the use of the governmental attorney-client privilege, consistently holding "that the public interest is furthered by extending the privilege to governmental entities.",580

In addition to finding judicial support for a governmental attorney-client privilege, Judge Kopf found a history of recognition by the government. According to a 1982 opinion issued by Assistant Attorney General Theodore Olson of the Office of Legal Counsel, both the inclusion of the governmental attorney-client privilege in the Freedom of Information Act and the functional analysis that established a corporate attorney-client privilege in Upjohn supported a governmental attorney-client privilege. ${ }^{581}$ The functional analysis for determining if the privilege is necessary focuses on two issues: (1) whether a governmental attorney-client privilege would protect and encourage candid communication and (2) whether it "would encourage the communication of relevant and helpful information." B82 " Because the Upjohn decision did not rely on the possibility of criminal liability for corporations, the inapplicability of such liability to governmental entities was insignificant to Judge Kopf. ${ }^{583}$

574. See supra Part V.A.2 (discussing the balancing test established in Nixon, which weighs the general interest of the President in keeping his communications confidential against the specific need for evidence in a criminal investigation to establish whether the executive privilege should apply).

575. See In re Grand Jury Subpoena Duces Tecum, 112 F.3d at 926-27 (Kopf, J., dissenting).

576. Id. at 930 (Kopf, J., dissenting) (quoting RESTATEMENT OF THE LAW (THIRD) GOVERNING LAWYERS $\S 124(1996))$.

577. Id. at 928 (Kopf, J., dissenting) (quoting Proposed FED. R. EVID. 503(a)(1)).

578. See id. (Kopf, J., dissenting).

579. See id. at 929 (Kopf, J., dissenting).

580. Id. at 930 (Kopf, J., dissenting).

581. See id. at 930-31 (Kopf, J., dissenting).

582. Id. at 931 (Kopf, J., dissenting).

583. See id. (Kopf, J., dissenting). 
With the establishment of a governmental attorney-client privilege, Judge Kopf found 28 U.S.C. $\S 535$ (b) to be consistent with, rather than inapposite to, the privilege. ${ }^{54}$ Agreeing with the view held by then-Assistant Attorney General Antonin Scalia, he found it would be "inappropriate to infer a congressional purpose to breach the universally recognized and longstanding confidentiality of the attorney-client privilege. ${ }^{585}$ Its existence does not affect the need of DOJ or any other government attorney to ensure the confidentiality of communications in order to provide adequate legal advice. ${ }^{586}$

To overcome a governmental attorney-client privilege, Judge Kopf believed that material should be subpoenaed by a grand jury. He would then require that "the special prosecutor make an initial threshold showing before the district court that the documents are: (a) specifically needed; (b) relevant; and (c) admissible. ${ }^{587}$ The court then would review the documents in camera to determine which actually were relevant and admissible. ${ }^{588}$ In this case, Judge Kopf would refuse to enforce the subpoena for three reasons. First, the courts had yet to decide whether a proper showing of need could overcome the governmental attorney-client privilege. Second, Mrs. Clinton has various constitutional rights that are implicated by intercepting her privileged communications without warning. ${ }^{589}$ In the future, however, the White House attorney-client privilege could give way to a grand jury subpoena as long as the procedural protections laid out in Nixon are recognized. ${ }^{590}$ Third, the common interest, which applies whenever communication was made to provide clients with needed legal services, expanded Mrs. Clinton's private attorney-client privilege to cover the conversations in question. ${ }^{59}$ Because the White House and Mrs. Clinton jointly decided to turn over the White House billing records to OIC, both clients, Mrs. Clinton as a representative of the White House and Mrs. Clinton in her private capacity, "legitimately needed the advice of separate lawyers in order to carefully and candidly respond to the Independent Counsel., ${ }^{, 92}$

d. In re Bruce R. Lindsey, ${ }^{593}$ 1998. Grand jury witness Bruce Lindsey claimed that the attorney-client privilege protected his conversations with other

584. See id. at 932 (Kopf, J., dissenting).

585. Id. (Kopf, J., dissenting).

586. See id. (Kopf, J., dissenting).

587. Id. at 927 (Kopf, J., dissenting).

588. See id. (Kopf, J., dissenting).

589. See id. at 938 (Kopf, J., dissenting). Unlike the Nixon case, which weighed the government's interest against the public interest, this case pits an individual interest against the public interest. Mrs. Clinton, as a private individual, is protected by both the Fifth and Sixth Amendments, and a violation of the attorney-client privilege might be a violation of her constitutional rights. Because such individual liberties were not at stake in Nixon, that case fails to provide complete guidance.

590. See supra Part V.A.2. The procedural protections established in Nixon include showing a specific need and relevance for each piece of evidence, showing that the information could not come from any other source, and presenting the evidence for an in camera review.

591. See In re Grand Jury Subpoena Duces Tecum, 112 F.3d at 939 (Kopf, J., dissenting).

592. Id. (Kopf, J., dissenting).

593. In re Bruce R. Lindsey (Grand Jury Testimony), 158 F.3d 1263 (D.C. Cir.), cert. denied sub nom. Office of President v. Office of Independent Counsel, 119 S. Ct. 466 (1998). 
grand jury witnesses, their attorneys, the President, White House attorneys, and the President's personal attorneys when OIC moved to compel testimony about the conversations during the investigation of the Monica Lewinsky matter. $^{594}$ Lindsey argued that, given his role as Deputy Counsel to the President, 'conversations regarding legal matters, such as the assertion of official privileges and the possibility of impeachment proceedings, were absolutely protected by a governmental attorney-client privilege. Additionally, he argued that the privilege protected advice given to the Office of the President concerning the continued fulfillment of the President's institutional duties in the face of other civil litigation that involved him. ${ }^{59}$ Lindsey claimed that the common-interest doctrine protected his communications with the President's personal attorneys. ${ }^{596}$

In support of an absolute governmental attorney-client privilege, the White House argued that the President's need for full and frank communications with his attorneys is comparable to that of a private individual or corporation, both of which enjoy a well-established attorney-client privilege. ${ }^{597}$ In this case, the legal advice of the White House Counsel was required to respond to a resolution introduced in the House of Representatives, which called for an inquiry into possible grounds for impeachment. ${ }^{598}$ Although both parties agreed that the White House Counsel could represent the President in the impeachment process, the White House Counsel's actual role in the fundamentally political process had not been determined. According to OIC, no absolute governmental attorney-client privilege existed, and even if a qualified privilege existed, OIC argued that because impeachment was a political rather than a judicial process, advice given by White House Counsel might not be legal in nature and therefore would not be protected by even a qualified attorney-client privilege. This was especially true given Lindsey's dual roles as Assistant to the President and as Deputy White House Counsel. Because the legal advice concerning impeachment did not have to come from the White House Counsel, OIC argued that the President could have relied on his personal lawyers if he wanted to ensure confidentiality. ${ }^{599}$

The Court of Appeals found that a qualified governmental attorney-client privilege existed. The court held that the privilege was overcome in this case by a sufficient showing of need for the subpoenaed communications in the context

594. See id. at 1267. The investigation resulted from an expansion of the Whitewater investigation of President Clinton's financial transactions when he was Governor of Arkansas. The inquiry included allegations of possible perjury, obstruction of justice, intimidation of witnesses, and other violations of federal law in connection with Paula Jones's sexual harassment suit against the President.

595. The President was involved in civil litigation with Paula Corbin Jones. See generally Clinton v. Jones, 117 S. Ct. 1636 (1997).

596. See In re Grand Jury Proceedings, 5 F. Supp. 2d 21, 30 (D.D.C. 1998).

597. See supra Part V.B.1.

598. See In re Bruce R. Lindsey (Grand Jury Testimony), 158 F.3d at 1276 (citing H.R. Res. 304, 105th Cong. (1997)).

599. See id. at 1276-77 
of a grand jury investigation. ${ }^{600}$ The court first established that a governmental attorney-client privilege existed before it faced the question of whether the privilege was absolute. It found authority establishing a governmental attorney-client privilege both in the law and in persuasive legal principles. Exemption five of the Freedom of Information Act excuses from mandatory disclosure "intra-agency memorandums or letters which would not be available by law to a party other than an agency in litigation with the agency," protecting those materials that otherwise would be protected by a governmental attorneyclient privilege. ${ }^{601}$ The Restatement (Third) of the Law Governing Lawyers extended the attorney-client privilege to government entities, ${ }^{602}$ and Proposed Federal Rule of Evidence 503 defined "client" in this context to include "a person, public officer, or corporation, association, or other organization or entity, either public or private." ${ }^{603}$ Although Rule 503 was not enacted, the court found that it accurately reflected what other courts, including the Supreme Court, have recognized as a common law practice. ${ }^{604}$

The practices of executive branch attorneys also evinced an understanding that governmental attorney-client privilege applied in some contexts. According to Assistant Attorney General Theodore Olsen of the Office of Legal Counsel, the privilege "functions to protect communications between government attorneys and client agencies or departments" in addition to protecting private attorney-client relationships. ${ }^{605}$ Previously, the Office of Legal Counsel had recognized that the privilege protected communications between government attorneys acting as private counsel for federal employees sued in their individual capacities. ${ }^{606}$

After establishing the existence of a governmental attorney-client privilege, ${ }^{607}$ the court addressed the larger issue of "whether an attorney-client privilege permits a government lawyer to withhold from a grand jury information relating to the commission of possible crimes by government officials and

600. See id. at 1278 . The Eighth Circuit had earlier held that a governmental attorney-client privilege did not exist at all. See In re Grand Jury Subpoena Duces Tecum, 112 F.3d 910, 921 (8th Cir.), cert. denied sub nom. Office of President v. Office of Independent Counsel, 117 S. Ct. 2482 (1997).

601. 5 U.S.C. $\$ 552$ (b)(5) (1994). The justification for this exemption rests on the ground that the agencies need full and frank communications with their attorneys, the same ground that justifies private and corporate attorney-client privileges. See In re Bruce R. Lindsey (Grand Jury Testimony), 158 F.3d at 1268-69.

602. Restatement (ThiRd) OF The LAw Governing Lawyers $\S 124$ (Proposed Final Draft No. 1, 1996).

603. PROPOSED FED. R. EVID. 503(a)(1), reprinted in 56 F.R.D. 183, 235 (1972).

604. See In re Bruce R. Lindsey (Grand Jury Testimony), 158 F.3d at 1268-69.

605. Id. at 1269 (quoting Theodore B. Olsen, Assistant Attorney General, Office of Legal Counsel, Confidentiality of the Attorney General's Communications in Counseling the President, 6 Op. Off. Legal Counsel 481, 495 (1982)).

606. See id. (citing Antonin Scalia, Assistant Attorney General, Office of Legal Counsel, Disclosure of Confidential Information Received by U.S. Attorney in the Course of Representing a Federal Employee (Nov. 30, 1976)).

607. The D.C. Circuit did not distinguish its holding that a governmental attorney-client privilege existed from the Eighth Circuit's holding that a governmental attorney-client privilege did not exist. 
others. ${ }^{, 608}$ In doing so, the court had to determine whether the privilege was absolute or qualified. Although a governmental attorney-client privilege existed, neither "policy nor experience" suggested to the court that a federal governmental entity could maintain the ordinary common law attorney-client privilege. ${ }^{609}$ In making this distinction, the court highlighted the special responsibilities that government lawyers have in light of their status as civil servants. ${ }^{610}$ The President's attempt to prevent disclosure of information to a grand jury inherently conflicts with his responsibility of investigating and prosecuting federal crimes, ${ }^{611}$ which stems from his constitutional responsibility to execute the laws faithfully. ${ }^{612}$ The privilege also runs counter to the strong public interest in uncovering illegal actions of government officials. Because "openness in government has always been thought crucial to ensuring that people remain in control of their government," the court determined that an absolute governmental attorney-client privilege that sequestered information from the public would represent a "gross misuse of public assets." 613 The court found the position of a government attorney analogous to that of a corporate attorney who tries to keep communications with corporate officers confidential from other officers and shareholders-an unacceptable practice that is not always in the best interests of the corporation. ${ }^{614}$

The court found further support for a qualified attorney-client privilege by comparing it to the well-established executive privilege. The court did not believe that communications outside the scope of the qualified executive privilege should be covered by an absolute governmental attorney-client privilege. In fact, the court found no grounds for distinguishing the President's legal advice from political advice concerning executive constitutional duties. ${ }^{615}$ The court did not expect that a qualified attorney-client privilege would chill candid communications between the President and White House Counsel because it would still protect all communications that did not relate to criminal activity. ${ }^{616}$ Furthermore, if the President required complete confidentiality, he could consult private counsel. ${ }^{67}$

Nor did the court fear that a qualified attorney-client privilege would irreversibly affect future Presidents faced with the possibility of impeachment pro-

608. 158 F.3d at 1271.

609. Id. at 1266 .

610. See supra Part V.B.2.

611. See In re Bruce R. Lindsey (Grand Jury Testimony), 158 F.3d at 1271-73.

612. See U.S. ConST. art II, \& 3 (stating that the President "shall take Care that the Laws be faithfully executed.").

613. In re Bruce R. Lindsey (Grand Jury Testimony), 158 F.3d at 1274 (quoting In re Grand Jury Subpoena Duces Tecum, 112 F.3d 910, 912 (8th Cir. 1997)).

614. See id. at 1276 (citing Garner v. Wolfinbarger, 430 F.2d 1093 (5th Cir. 1970) (holding that attorney-client privileges between corporate attorneys and corporate officers were not absolute, and accordingly that corporate officers must be aware that their conversations with corporate attorneys may not be kept confidential from shareholders)).

615. See id. at 1266.

616. See id. at 1276 (citing United States v. Nixon, 418 U.S. 683, 712-13 (1974)).

617. See id. 
ceedings. The court rejected the idea that communications would be chilled; although OIC would pass information discovered by the grand jury to Congress, the court did not recognize the fact that the exception to the governmental attorney-client privilege for grand jury investigations would abrogate the absolute protection the attorney-client communications otherwise would have enjoyed in congressional impeachment proceedings. ${ }^{618}$ The court could not determine what the common law attorney-client privilege would protect in impeachment proceedings because neither the House of Representatives nor the Senate had established procedures or evidentiary rules for the political impeachment process. Furthermore, if the advice were deemed political rather than legal, the attorney-client privilege would not apply because the advice would fall under the purview of executive privilege. ${ }^{619}$

A qualified governmental attorney-client privilege was further supported by the strong congressional preference for executive branch employees to disclose all evidence of criminal activity. According to 28 U.S.C. $\S 535(\mathrm{~b})$, "[a]ny information ... received in a department or agency of the executive branch of the Government relating to violations of title 18 involving Government officers and employees shall be expeditiously reported to the Attorney General." "Although the Office of the President does not clearly fall within the meaning of "office" or "agency" as defined by the statute, the court interpreted the statute to suggest that "all government employees, including lawyers, are duty-bound not to withhold evidence of federal crimes." 221 This interpretation was reinforced by the practice and policy of the Clinton Administration, which officially recognized a duty under $\S 535$ (b) to turn over criminal evidence to the Attorney General. ${ }^{622}$

On the merits, the court found that communications concerning legal advice given in connection with the Paula Jones civil suit were not privileged because the jurisdiction of OIC's investigation did not yet include issues arising out of that lawsuit. The President would have no reason to discuss impeachment in relation to the civil suit until OIC had jurisdiction in that area.

The court rejected White House arguments that, in the event the governmental attorney-client privilege applied, the private attorney-client privilege shared by Clinton and his personal lawyer protected the communications in question. $^{63}$ Although conversations between attorneys and clients made through intermediaries are sometimes protected by the attorney-client privi-

618. See id. at 1276-77

619. See id. Only the issue of attorney-client privilege was raised on appeal.

620. 28 U.S.C. $\$ 535$ (b) (1994).

621. See In re Bruce R. Lindsey (Grand Jury Testimony), 158 F.3d at 1274-75. This position is also supported by former White House Counsel Lloyd Culter and Solicitor General Robert Bork, both of whom expressed a belief that they had a statutory duty to report any evidence of criminal wrongdoing within the executive branch to the Attorney General. This included any criminal activity by the President.

622. See id. at 1275 (quoting Reply Brief for the Office of the President at 7, Office of the President v. Office of the Independent Counsel, 117 S. Ct. 2482 (1997) (No. 96-1783)).

623. See id. at 1279-80. 
lege, the court did not consider this intermediary doctrine to be applicable to Lindsey. The district court was not convinced that the White House needed to use Lindsey as an intermediary, and even though the Court of Appeals would not second-guess the decisions of the executive branch as to what measures were necessary "to avoid undue disruptions to the President's ability to carry out his official responsibilities," sey's intermediary role. Lindsey had added his own legal opinion and changed the nature of the legal advice rendered in the message, behavior inconsistent with the purpose of the intermediary doctrine. ${ }^{625}$ Furthermore, the court questioned the propriety of using a government attorney in this manner. ${ }^{62}$

The court also rejected the argument that the common-interest doctrine protected the conversations between Lindsey, Clinton, and Clinton's private attorneys. The court found Lindsey to have "a fundamentally different position" than a private attorney because his "obligation not to withhold relevant information acquired as a government attorney remains the same regardless of whether he acquired the information directly from the President or from the President's personal counsel." ${ }^{627}$ As a result of this duty, his communications before the grand jury were protected neither by the governmental attorneyclient privilege nor by the common-interest doctrine.

As in the Eighth Circuit, the decision regarding the existence and scope of the governmental attorney-client privilege was not unanimous. In his dissenting opinion, D.C. Circuit Judge Tatel expressed concern that the court unnecessarily limited the attorney-client privilege for future Presidents without determining the precise nature of the Lindsey communications or whether they fell within the ambit of the privilege. ${ }^{628} \mathrm{He}$ predicted a chilling effect on candid conversations between the President and his government attorneys. ${ }^{629}$ Moreover, he considered inapplicable the qualifications pertinent to the constitutionally based, broader executive privilege to the narrower attorney-client privilege, which is based on the common law recognition of a lawyer's special function in rendering legal advice. ${ }^{630}$

Unlike the majority, Judge Tatel found no difference in the responsibilities of private attorneys and executive branch attorneys. ${ }^{631}$ Because the text of 28 U.S.C. $\S 535(b)$ does not specifically reference the Office of the President, Judge Tatel did not feel that it imposed additional responsibilities upon the President's attorneys. In his view, compliance with the spirit of the statute requires neither the disclosure of conversations with the President of the United States nor reporting any potential criminal violation by one presidential subor-

624. Id. at 1280.

625. See id. at 1281.

626. See id. at 1281-82.

627. Id. at 1283.

628. See id. (Tatel, J., dissenting).

629. See id. at 1284 (Tatel, J., dissenting).

630. See id. at 1285 (Tatel, J., dissenting).

631. See id. (Tatel, J., dissenting). 
dinate, the President's attorney, to another presidential subordinate, the Attorney General. ${ }^{632}$ Because all attorneys take an oath to uphold the Constitution of the United States, a distinction based on any special constitutional responsibilities of federal government attorneys could not be relied upon to eliminate the traditional attorney-client relationship. ${ }^{633}$

Judge Tatel further argued that reason and experience, the tools of Federal Rule of Evidence 501, do not recommend the abrogation of that traditional attorney-client privilege in this context. Judge Tatel reasoned that, due to the President's "unique position in the constitutional framework" and the wide range of responsibilities vested solely in him, his need for fully informed, confidential legal advice is unparalleled. ${ }^{634}$ The public's strong interest in the President's ability to perform his constitutional duties further supports a privilege that protects him from the distraction of "false or frivolous accusations." 635 Being forced to draw a line between what should be discussed with private attorneys and what should be discussed with White House Counsel may distract the President, whose individual persona has become increasingly difficult to separate from his official one. This point is particularly salient in the wake of Watergate and the resulting escalation in public scrutiny. ${ }^{636}$ Judge Tatel did not believe that benefiting from the traditional common law attorney-client privilege would place the President above the law. In addition to the threat of criminal penalties, his political accountability to the public and the possibility of impeachment proceedings would deter him from criminal conduct. ${ }^{637}$ If the independent counsel reported to Congress that critical grand jury information had been withheld, Congress could then determine in the proper political setting whether the information was needed without fundamentally weakening the governmental attorney-client privilege. ${ }^{638}$

On the merits, Judge Tatel believed it necessary, due to Lindsey's dual roles as Deputy White House Counsel and Special Assistant to the President, to determine the content of the conversations in question before deciding whether the attorney-client privilege applied. The White House would have to demonstrate that the services provided were in fact legal services for the attorneyclient privilege to apply. ${ }^{639}$ Judge Tatel found no reason to address a governmental attorney-client privilege if the privilege did not actually apply, and he certainly found no reason to destroy it in this context. ${ }^{640}$

632. See id. (Tatel, J., dissenting).

633. See id. at 1286 (Tatel, J., dissenting).

634. Id. (Tatel, J., dissenting) (quoting Nixon v. Fitzgerald, 457 U.S. 579, 653 (1952) (Jackson, J., concurring)).

635. Id. at 1287 (Tatel, J., dissenting).

636. See id. (Tatel, J., dissenting).

637. See id. (Tatel, J., dissenting).

638. See id. (Tatel, J., dissenting).

639. See id. at 1288 (Tatel, J., dissenting).

640. See id. (Tatel, J., dissenting). 
e. Conclusion. The law regarding the existence of a governmental attorney-client privilege is far from settled. The Eighth Circuit and the D.C. Circuit took very different approaches in reaching their decisions, the former starting with the premise that the privilege never existed, and the latter from the premise that the privilege existed but might not apply. Both courts had strong dissenting opinions, and the Supreme Court has yet to grant certiorari to decide the issue.

3. Problems with the Work-Product Doctrine. The work-product doctrine, which protects the documents prepared by attorneys in anticipation of trial, is connected to the attorney-client privilege. ${ }^{641}$ Both seek to ensure that attorneys can work on a client's behalf without fearing the release of their communications or documents, thereby exposing their trial strategy or rejected theories of law. Claiming the protection of the work-product doctrine for materials prepared by government attorneys involves the same conflicts as claiming the protection of the governmental attorney-client privilege itself. In both situations, the personal interest of the government employee in seeking to avoid criminal sanctions may differ from his or her official interest. ${ }^{642}$ The Supreme Court has not made a definitive decision regarding the scope of either the attorney-client privilege or the related work-product doctrine in the context of government lawyers.

In re Grand Jury Subpoena Duces Tecum addressed the issue of the attorney work-product doctrine. The White House cited the doctrine in refusing to comply with OIC's subpoena for the production of "all documents created during meetings attended by any attorney from the Office of the President and Hillary Rodham Clinton... pertaining to several Whitewater-related subjects." "643 The White House claimed that its lawyers had been preparing for OIC's investigation and that their work-product for this adversarial proceeding therefore fell under the purview of the work-product doctrine. The White House further suggested that "anticipated litigation" included anticipated congressional hearings. Based on the distinction made between Mrs. Clinton's personal and public personas, ${ }^{644}$ the court rejected the White House's argument. OIC was investigating Mrs. Clinton in her personal capacity, while the White House Counsel represented her in her public capacity. The White House could not claim work-product immunity for documents prepared on behalf of a third person because the doctrine applies only to preparations made on behalf of a client in anticipation of upcoming adversarial proceedings, including investigative legislative hearings. ${ }^{645}$ Even if the White House anticipated that a congressional investigation of the President might result from this $\mathrm{OIC}$ investigation,

641. See Fed. R. CIV. P. 26(b)(3).

642. See, e.g., In re Grand Jury Proceedings Subpoena Duces Tecum, 112 F.3d 910, 920 (8th Cir.), cert. denied sub nom. Office of President v. Office of Independent Counsel, 117 S. Ct. 2482 (1997).

643. Id. at 913 (quoting Subpoena Rider at 1).

644. See supra notes 570-571 and accompanying text.

64.5. See In re Grand Jury Subpoena Duces Tecum, 112 F.3d at 924. 
the court refused to use the work-product doctrine to protect documents in order to prevent the possibility of future political harm.

\section{The Protective Function Privilege}

1. History of the Protective Function Privilege. The protective function privilege was first claimed in 1998 by the Secretary of the Treasury in response to a subpoena by OIC to compel Secret Service agents to testify before the grand jury investigating the Monica Lewinsky matter. ${ }^{646}$ Although agents had testified in past judicial and nonjudicial proceedings, ${ }^{647}$ this was the first time a grand jury had sought to compel their testimony about observations made while executing their protective function. In response, the Secretary of the Treasury, as head of the department responsible for the Secret Service, claimed that the testimonies subpoenaed were privileged. ${ }^{648}$

2. Problems with Recognizing the Protective Function Privilege. The protective function privilege, like any other privilege, prevents the grand jury or other investigative body from obtaining evidence during an investigation. The privilege, as initially articulated by the Treasury Secretary, would protect

information obtained by Secret Service personnel while performing their protective function in physical proximity ... [, but it would] not apply, in the context of a federal investigation or prosecution, to bar testimony by an officer or agent concerning observations or statements that, at the time they were made, were sufficient to provide reasonable grounds for believing that a felony has been, is being, or will be committed. $^{649}$

Unlike both the attorney-client privilege and the executive privilege, which protect the confidentiality of communications, the protective function privilege protects personal observations made by Secret Service agents while performing their protective function. ${ }^{650}$ According to OIC, such a privilege "is unprecedented in American law" and contradicts the "fundamental and comprehensive' need to develop facts in a grand jury investigation."

As with other evidentiary privileges, tension arises when the protective function privilege is used to prevent the disclosure during a criminal investigation of information held by the executive branch. Any steps taken to prevent a

646. The Office of the Independent Counsel's jurisdiction in this investigation included "whether Monica Lewinsky or others suborned perjury, obstructed justice, intimidated witnesses, potential witnesses, attorneys, or others concerning the civil case of Jones v. Clinton." Letter from Kenneth W. Starr, Independent Counsel, to Charles F.C. Ruff, Counsel to the President, at 1 (Apr. 28, 1998) (on file with authors).

647. See In re Grand Jury Proceedings, No. 98-148 (NHJ), 1998 WL 272884, at *3 (D.D.C. May 22, 1998) (noting that the Secret Service has testified in proceedings regarding Nixon's taping system and John Hinckley's assassination attempt on the life of President Reagan).

648. See id. at *5.

649. In re Sealed Case, 148 F.3d 1073, 1075 (D.C. Cir. 1998) (citation omitted).

650. See Letter from Kenneth W. Starr, supra note 646, at 2.

651. Id. 
full factual record from being established run contrary to the executive branch's constitutional responsibility to enforce the law. ${ }^{652}$

Federal Rule of Evidence 501 allows for the evolutionary development of privileges and provides that new evidentiary privileges, such as the protective function privilege, "shall be governed by the principles of the common law as they may be interpreted ... in the light of reason and experience." According to the Supreme Court, this standard requires the reviewing court to consider (1) whether the privilege is "historically rooted in federal law; (2) whether any states have recognized the privilege; and (3) public policy interests... [specifically] whether the new privilege 'promotes sufficiently important interests to outweigh the need for probative evidence.",653 Despite the Supreme Court's reluctance to create new privileges, it will be more inclined to do so "if the public good transcend[s] the normally predominant principle of utilizing all rational means for ascertaining the truth."

Strong policy arguments both support and oppose the protective function privilege. The main argument supporting the privilege begins with the assertion that the public has a strong interest in protecting the President's life because "[a] President's death in office has world wide repercussions and affects the security and future of the entire nation." "655 A President's lack of confidence in the discretion of his protectors may deny agents the proximity needed to perform the "cover and evacuate" method of protection, which requires them to be close enough to "literally put their hands on the President" and remove him from harm's way in a split-second. ${ }^{656}$ If they knew that agents could be compelled to testify about their observations before a grand jury, Presidents might feel increasingly reluctant to cooperate, thus endangering their lives and consequently the public interest. ${ }^{657}$ Full cooperation between the President and his protectors is essential, as "the difference of even a few feet between a President and his protective detail could make the difference between life or death." 658 For example, according to studies of photographs of the assassination, President Kennedy might have avoided death had he not ordered Secret Service

652. See U.S. ConST. art. II, $\S 3$ (The President "shall take Care that the Laws be faithfully executed").

653. In re Grand Jury Proceedings, No. 98-148 (NHJ), 1998 WL 272884, at *1 (D.D.C. May 22, 1998) (quoting Jaffee v. Redmond, 518 U.S. 1, 9-10 (1996)).

654. Jaffee v. Redmond, 518 U.S. 1, 9 (1996) (quoting Trammel v. United States, 445 U.S. 40, 50 (1980)).

655. Roy v. United States, 416 F.2d 874, 877 (9th Cir. 1969).

656. Opposition to the Independent Counsel's Motion to Compel at 11-12, In re Grand Jury Proceedings, 1998 WL 272884 (D.D.C. May 22, 1998) (No. 98-148 (NHJ)) (citing Declaration of Lewis Merletti II 7, Declaration of John W. Magaw II 4, Declaration of Elijay Bowron I 5).

657. See id. (citing REPORT OF THE PRESIDENT's COMMISSION ON THE AsSASSINATION OF PRESIDENT KENNEDY 506 (1964) ("Warren Report")).

658. In re Sealed Case, 148 F.3d 1073, 1075 (D.C. Cir. 1998) (quoting Declaration of Lewis C. Merletti II 12). 
agents off the running boards of his presidential limousine. ${ }^{659}$ Proximity to the President is crucial to protection, as indicated by the different outcomes of assassination attempts against Presidents McKinley and Reagan. President Reagan's life was saved by an agent close enough to throw his own body between the President and the assassin's bullet, while President McKinley, the day before his murder, had removed the agent detailed to remain at his side. ${ }^{660}$

Critics of the protective function privilege argue that other factors outweigh any potential negative effects from the possibility of testimony by Secret Service agents before a federal grand jury. ${ }^{661}$ For many years, the Secret Service has been able to draw on a President's strong interest in his own physical safety to convince him that a close protective envelope is needed twenty-four hours a day, 365 days a year. The President's strong personal interest in receiving this protection will not change if the protective function privilege is not recognized. Only if the President were to engage in criminal behavior would close cooperation with Secret Service agents become a problem. ${ }^{662}$

3. In re Grand Jury Proceedings, May 1998 / In re Sealed Case, July $1998 .^{663}$ Presented with the Office of Independent Counsel's motion to compel the grand jury testimony of Secret Service agents, D.C. District Judge Norma Johnson refused to recognize the existence of the protective function privilege claimed by the Secret Service. ${ }^{664}$ Judge Johnson did not believe that the Secret Service had met requirements for establishing a new evidentiary privilege pursuant to Federal Rule of Evidence 501. No federal or state history supported the privilege, and the Constitution did not support it. ${ }^{665}$ In distinguishing this privilege from the recently recognized patientpsychotherapist privilege, ${ }^{66}$ Judge Johnson emphasized the fact that the latter privilege had some history of recognition in both federal and state appellate courts and was among the nine specific privileges recommended by an advisory committee proposing new evidentiary privilege rules. ${ }^{667}$ While affirming Judge

659. See Opposition to the Independent Counsel's Motion to Compel, at 15. President Kennedy, like his predecessors, demonstrated a strong desire to maintain his privacy and even refused to allow the Secret Service to ride in the passenger compartment of his car. See id. at $16 \&$ n. 16.

660. See id. at 18 .

661. See In re Grand Jury Proceedings, No. 98-148 (NHJ), 1998 WL 272884, at *4 (D.D.C. May 22, 1998).

662. See id. ("When people act within the law, they do not ordinarily push away those they trust or rely upon for fear that their actions will be reported to a grand jury. It is not at all clear that a President would push Secret Service protection away if he were acting legally or even if he were engaged in personally embarrassing acts.").

663. In re Sealed Case, 148 F.3d 1073 (D.C. Cir. 1998), is the appellate court opinion concerning the district court's decision in In re Grand Jury Proceedings, No. 98-148 (NHJ), 1998 WL 272884 (D.D.C. May 22, 1998).

664. See In re Grand Jury Proceedings, 1998 WL 272884, at *5.

665. See id. at *2-*3.

666. See Jaffee v. Redmond, 518 U.S. 1 (1996) (recognizing the existence of a federal patientpsychotherapist privilege for the first time).

667. See In re Grand Jury Proceedings, 1998 WL 272884 at *3 (citing Jaffee v. Redmond, 518 U.S. at $7,9 \mathrm{nn} .7 \& 14)$. 
Johnson's analysis, the D.C. Circuit pointed out that given the novelty of OIC's demand for testimony from the Secret Service, the absence of precedent at the state or federal level was not determinative. ${ }^{668}$ Therefore, the Secret Service would have to demonstrate that recognizing the privilege would "materially enhance presidential security by lessening any tendency of the President to 'push away' his protectors in situations where there is some risk to his safety," a burden of proof it ultimately failed to carry. ${ }^{669}$

In support of the privilege, three of the most recent Secret Service directors and former President George Bush expressed concern that compelling Secret Service testimony would have an irreversible negative effect on the relationship between the President and his protectors. ${ }^{670}$ In an open letter to Secret Service Director Lewis Merletti, President Bush assured Merletti that "had I felt they would be compelled to testify as to what they had seen or heard, no matter what the subject, I would not have felt comfortable having them close in." However, the effects of allowing testimony were far from unanimous, even among former Presidents. Former Presidents Ford and Carter publicly supported the idea that Secret Service agents "should be required to testify" in the context of criminal investigations. ${ }^{67}$

Judge Johnson acknowledged that " $[\mathrm{t}]$ he physical safety of the President ... [is] clearly of paramount national importance," but decided that this consideration was "not strong enough [either] to overcome the grand jury's substantial interest in obtaining evidence of crimes or to cause th[e] Court to create a new testimonial privilege." ${ }^{673}$ The President's strong interest in his own safety would prevent him from pushing the Secret Service away when he was "acting legally or even if he were engaged in personally embarrassing acts. ${ }^{.674}$ In fact, in the past, Secret Service agents had testified in both judicial and nonjudicial proceedings without asserting a protective function privilege ${ }^{675}$ indicating that absolute confidentiality was not required or even expected of Secret Service agents. Secret Service agents do not sign confidentiality agreements, ${ }^{676}$ and although former agents have even published books based on observations made

668. See In re Sealed Case, 148 F.3d at 1076 ("This appears to be the first effort in U.S. history to compel testimony by agents guarding the President. ... In these circumstances, we do not regard the absence of precedent as weighing heavily against recognition of the privilege.").

669. Id. The D.C. Circuit argued that this type of high standard is not unique to the establishment of the protective function privilege, noting that the Supreme Court has held that proponents of privileges must provide "a compelling empirical case" for their necessity. Id. (citing Branzburg v. Hayes, 408 U.S. 665, 693-94 \& n.32 (1972)).

670. See In re Grand Jury Proceedings, 1998 WL 272884, at *4 ("The Secret Service did not present any letter or declaration from President Clinton.").

671. Letter from Former President George Bush to Lewis Merletti, Secret Service Director (Apr. 15,1998 ) (on file with authors).

672. In re Sealed Case, 148 F.3d at 1076-77.

673. In re Grand Jury Proceedings, 1998 WL 272884, at *4-*5.

674. Id. at *4.

675. See id. at *3.

676. See In re Sealed Case, 148 F.3d at 1077. 
while performing their official protective function, ${ }^{677}$ no evidence suggested that such publications caused Presidents to push the Secret Service away.

Judge Johnson was further persuaded by the relevant legislation. Federal law explicitly requires the President and the Vice President to accept the protection of Secret Service agents ${ }^{679}$ and defines some of the Secret Service's responsibilities. Even though Secret Service agents of necessity would witness some of these officials' most private moments, the legislation makes no provisions for the possibility of an evidentiary privilege.

Moreover, as employees of the executive branch, the agents have a duty to report criminal activities to the proper authorities, a responsibility that would be hampered if an agent's observations were presumptively protected. ${ }^{681}$ The uncertainty created by the exception to the privilege could encourage the President to push away his protective envelope just as much as he might without the privilege. $^{682}$ After all, the President might not even know if the agent were aware that he was witnessing a criminal act, and only if he were unaware would that observation remain privileged. ${ }^{683}$

Although Judge Johnson did not believe the privilege had been properly invoked in the case, she did not resolve the issue of who should assert the privilege. ${ }^{684}$ OIC had argued that the President should control and, in this case, personally waive the privilege, as he would the executive privilege. ${ }^{685}$ On the other hand, DOJ analogized the protective function privilege to the state secrets privilege because both protected national security interests. It argued that the privilege therefore belonged to the United States, and the Secretary of the Treasury, as the head of the department responsible for the Secret Service, had the power (though not necessarily the exclusive power) to assert it. ${ }^{686}$ Because $^{\circ}$ neither Judge Johnson nor the D.C. Circuit recognized the existence of a protective function privilege in this situation, ${ }^{687}$ which member of the executive branch should control such a privilege is still unclear.

677. See In re Grand Jury Proceedings, 1998 WL 272884, at *4. Former Secret Service agent Seymour Hersh published THE DARK SIDE OF CAMELOT (1997), which describes four agents' revealing observations of President Kennedy, and former agent Dennis V.N. McCarthy with Philip W. Smith published Protecting THE PREsident: THE Inside STORY OF A SECRET SERVICE AGENT (1985). See id.

678. See 1998 WL 272884 at *4.

679. See 18 U.S.C. $\$ 3056$ (a) (1994) (excluding the President and Vice President from those who can decline Secret Service protection).

680. See In re Grand Jury Proceedings, 1998 WL 272884, at *2.

681. See In re Sealed Case, 148 F.3d 1073, 1078 (D.C. Cir. 1998) (citing 28 U.S.C. \$ 535(b) (1994)).

682. See id. at 1077.

683. See id.

684. See In re Grand Jury Proceedings, 1998 WL 272884, at *5.

685. See id.

686. See Opposition to the Independent Counsel's Motion to Compel at 31-32, In re Grand Jury Proceedings (No. 98-148 (NHJ)).

687. See In re Sealed Case, 148 F.3d 1073, 1074 (D.C. Cir. 1998) (expressing "no opinion about the propriety of asserting a protective function privilege in other legal proceedings"). 
4. Clinton v. Jones, January $1998 .^{688}$ In the civil litigation between Paula Corbin Jones and President Clinton, involving claims of sexual harassment at the time Clinton was Governor of Arkansas, lawyers for Jones attempted to subpoena the testimony of Secret Service agents. ${ }^{689}$ District Judge Susan Webber Wright found "no need for this Court to determine the existence or applicability of any privilege... as the issues raised by the Secret Service's motion can be resolved on other grounds." ${ }^{690}$ Judge Wright denied the motion to compel the agents' testimony partly because the resulting evidence would not be "essential to the core issue in the case," presumably because the alleged incidents had occurred before Clinton had been nominated for President and before he had received Secret Service protection. ${ }^{691}$ She also based her decision on concerns that such testimony could interfere with the independent counsel's concurrent criminal investigation, and possibly jeopardize the President's safety given "the numerous 'leaks' of the sealed information in the case."

Although she never recognized an official protective function privilege, Judge Wright did agree "that the discovery sought by plaintiff could possibly provide critical information at the core of how the Secret Service actually functions and provide those with hostile intent toward the President with important information to use in piercing the Secret Service's protection." such "unauthorized disclosure" was "unacceptable, especially where the information sought by the plaintiff from the Secret Service [was] not essential to her case." ${ }^{694}$ Even though she claims not to have reached a decision regarding the existence of the protective function privilege, these statements seem to indicate that Judge Wright would recognize a qualified protective function privilege. In weighing the need for information from the Secret Service against the value of protecting the details of their protective work, she seemed to use the balancing test employed by the Supreme Court in Nixon ${ }^{695}$ to analyze the scope of the qualified executive privilege.

5. Conclusion. Although Judge Johnson refused to recognize the existence of the protective function privilege, the willingness of Judge Wright to consider the consequences of Secret Service testimony on the President's safety leaves open the possibility that such a privilege may be recognized in the future. Although the Supreme Court did not grant certiorari to resolve the issue, Justices Ginsburg and Breyer dissented, expressing their view that the Court should be the "definitive judicial arbiter in this case." "696 Justice Breyer argued

688. 117 S. Ct. 1636 (1997).

689. The case was eventually settled out of court.

690. Order Protecting Secret Service from Testimony, Jones v. Clinton, No. LR-C-94-920 (E.D.

Ark. Jan. 30, 1998) (on file with authors).

691. Id.

692. Id.

693. Id.

694. Id.

695. See supra Part V.A.2.

696. Rubin v. United States, 119 S. Ct. 461, 461 (1998) (Ginsburg, J., dissenting). 
that the law "should take special account of the obvious fact that serious physical harm to the President is a national calamity-by recognizing a special governmental privilege where needed to help avert the calamity." ${ }^{697}$ At this time, however, the existence of the privilege is "legally uncertain." 698

\section{Conclusion: Privileges}

The recent litigation by OIC deserted the previous system of case-by-case compromise within the executive branch over the scope of governmental privileges. One effect of the independent counsel statute, therefore, was the creation of substantially more case law on the executive privilege, governmental attorney-client privilege, and protective function privilege. These decisions may become largely moot if the Act is repealed and the prior practice of intrabranch and inter-branch compromise is restored. On the other hand, the restrictive language and interpretations of some of the decisions might have a deleterious effect on the ability of the executive branch and the President to carry out their constitutional functions. The long-term impact of privilege litigation under the independent counsel statute remains to be seen.

\section{VI}

\section{CONCLUSION}

The independent counsel statute has created a large body of law that, but for the Act's enactment, might never have been developed. Even if the Act expires in 1999 and is never reenacted, the law the Act generated will remain. While the technicalities of the triggering mechanisms may disappear, the balance that Congress fought so long and hard to strike properly-between too much deference to and trust in the executive branch, and too easily and too often requiring an outside investigator-will endure. The law of the Act's triggering mechanisms will inform and guide future debates about when and how independent prosecutors ought to be appointed. Similarly, the legal issues raised by the Act's interaction with other actors in the political system will persist. Future independent counsels, under a renewed Act or otherwise, will no doubt have contentious relationships with DOJ, Congress, the courts, and others. Politicians and investigators alike would be well served to learn from the legal principles and problems the Act exposed. Finally, the scope of the government's evidentiary privileges is now far more litigated than ever before. The courts will continue to look to these cases for guidance, often in cases not arising from independent counsel investigations. Whether the Act has damaged the government's position in court is still unclear. In the end, the independent counsel statute may be but a short experiment in political accountability in our nation's history. The law generated by the statute, however, is timeless.

697. Id. at 462 (Breyer, J., dissenting).

698. Id. at 465 (Breyer, J., dissenting). 